\title{
Sustainable Application of Biosorption and Bioaccumulation of Persistent Pollutants in Wastewater Treatment: Current Practice
}

\author{
Cătălina Filote ${ }^{1,2}$, Mihaela Roșca ${ }^{1}$, Raluca Maria Hlihor ${ }^{1, * \mathbb{D}}$, Petronela Cozma ${ }^{1,2, *}$, Isabela Maria Simion ${ }^{1}$, \\ Maria Apostol ${ }^{1}$ and Maria Gavrilescu ${ }^{2,3}$
}

1 Department of Horticultural Technologies, Faculty of Horticulture, "Ion Ionescu de la Brad" Iasi University of Life Sciences, 3 Mihail Sadoveanu Alley, 700490 Iasi, Romania; catalina.filote@uaiasi.ro (C.F.); mihaelarosca@uaiasi.ro (M.R.); simion.i@uaiasi.ro (I.M.S.); mariabrinza2007@yahoo.com (M.A.)

2 Department of Environmental Engineering and Management, "Cristofor Simionescu" Faculty of Chemical Engineering and Environmental Protection, "Gheorghe Asachi" Technical University of Iasi, 73 Prof. D. Mangeron Blv., 700050 Iasi, Romania; mgav@tuiasi.ro

3 Academy of Romanian Scientists, 3 Ilfov Street, 050094 Bucharest, Romania

* Correspondence: raluca.hlihor@uaiasi.ro (R.M.H.); petronela_cozma@ch.tuiasi.ro (P.C.)

\section{check for}

updates

Citation: Filote, C.; Roșca, M.; Hlihor, R.M.; Cozma, P.; Simion, I.M.

Apostol, M.; Gavrilescu, M. Sustainable Application of

Biosorption and Bioaccumulation of Persistent Pollutants in Wastewater Treatment: Current Practice. Processes 2021, 9, 1696. https://doi.org/ $10.3390 /$ pr9101696

Academic Editor: Jose

Manuel Gomez Montes de Oca

Received: 31 August 2021

Accepted: 18 September 2021

Published: 22 September 2021

Publisher's Note: MDPI stays neutral with regard to jurisdictional claims in published maps and institutional affiliations.

Copyright: (c) 2021 by the authors. Licensee MDPI, Basel, Switzerland. This article is an open access article distributed under the terms and conditions of the Creative Commons Attribution (CC BY) license (https:// creativecommons.org/licenses/by/ $4.0 /)$

\begin{abstract}
Persistent toxic substances including persistent organic pollutants and heavy metals have been released in high quantities in surface waters by industrial activities. Their presence in environmental compartments is causing harmful effects both on the environment and human health. It was shown that their removal from wastewaters using conventional methods and adsorbents is not always a sustainable process. In this circumstance, the use of microorganisms for pollutants uptake can be seen as being an environmentally-friendly and cost-effective strategy for the treatment of industrial effluents. However, in spite of their confirmed potential in the remediation of persistent pollutants, microorganisms are not yet applied at industrial scale. Thus, the current paper aims to synthesize and analyze the available data from literature to support the upscaling of microbialbased biosorption and bioaccumulation processes. The industrial sources of persistent pollutants, the microbial mechanisms for pollutant uptake and the significant results revealed so far in the scientific literature are identified and covered in this review. Moreover, the influence of different parameters affecting the performance of the discussed systems and also very important in designing of treatment processes are highly considered. The analysis performed in the paper offers an important perspective in making decisions for scaling-up and efficient operation, from the life cycle assessment point of view of wastewater microbial bioremediation. This is significant since the sustainability of the microbial-based remediation processes through standardized methodologies such as life cycle analysis (LCA), hasn't been analyzed yet in the scientific literature.
\end{abstract}

Keywords: heavy metals; microorganisms; persistent organic pollutants; removal mechanisms; process scale-up

\section{Introduction}

In modern society, due to expansion of industrial and agricultural activities, an increasing number of toxic compounds are being released into the environment. Basically, natural ecosystems are not able to break down such pollutants and they are highly accumulated in air, water, soil and finally in the food chain [1,2]. Water has a very important role in the metabolism of living organisms while most biochemical reactions take place in its presence [3]. Today, water pollution is one of the main environmental problems facing humanity, especially as a result of the direct or indirect discharge into water bodies of contaminated effluents from various anthropogenic sources $[2,4,5]$. The quality of natural water resources often needs to be improved to meet the qualitative requirements of consumers (such as drinking water, irrigation, industrial, for agro-zootechnical farms, etc.) due to the intensification and diversification of their pollution [6]. 
A huge concern is related to persistent, bioaccumulative, and toxic pollutants (PBTs). PBTs may be classified in inorganic or organic compounds or organometallic and other metallic complexes [7]. These environmental pollutants show high capacity and resistance against degradation under the action of abiotic and biotic factors, which gives them a high mobility into the environment. Their main classes are divided in persistent organic pollutants (POPs) (dioxins and furans, pesticides, chlorinated aromatic hydrocarbons, halogenated ethers, polychlorinated biphenyls-PCBs, polycyclic aromatic hydrocarbonsPAHs, perfluorinated detergents, polybrominated diphenyl ethers-PBDEs) and persistent inorganic pollutants (PIPs) (heavy metals-HMs such as lead, mercury, cadmium and chromium) [7,8]. Their persistence is mainly associated with a high (bio)accumulation potential and high toxicity for living organisms [9].

PBTs are accountable for long-transport distances, high stability and high persistence. For example, PCBs are still found in different environmental compartments including animal tissues even though they are banned or restricted in many countries since 1970s [7]. For example, Rigét et al. [10] studied the evolution trends of PCBs during 6 years' time in Arctic biota and observed a decrease in the annual mean concentrations per year. In the ArcRisk project, Carlsson et al. [11] investigated the levels of PCBs and other POPs of several Arctic food products from a food market located in Nuuk, Greenland. The highest PCB concentrations were detected in narwhal mattak (frozen skin and blubber) followed by seal meat and salmon species. The main dominant congeners of PCBs were associated with PCB-153, PCB-138, PCB-118 and PCB-101 [11]. In line with the above findings, mercury or other metals were also detected in different fish tissues. For example, Yi et al. [12] in line with other authors $[13,14]$, observed that the sediment is the major reservoir for trace metal pollution playing an important role in HMs uptake by fish. Although large concentrations of HMs are released in water bodies, the detected concentrations of HMs (such as $\mathrm{Cu}, \mathrm{Zn}, \mathrm{Pb}, \mathrm{Cd}, \mathrm{Hg}, \mathrm{Cr}$ and $\mathrm{As}$ ) were highest in the sediments, intermediate in fish and lowest in the water. This is because HMs are compounds with low solubility in water, do not degrade in water, being absorbed and accumulated on the lower layers of sediments. Further, sediments are habitats and a source of food for benthic fauna. Thus, pollutants may pose direct or indirect toxic effects on aquatic flora and fauna [12].

As a consequence, the presence of toxic pollutants in environmental compartments is causing harmful effects both on the environment and human health. Due to their persistence, HMs and POPs end up bioaccumulating along the food chain $[12,15,16]$, people getting exposed to these pollutants through inhalation, by ingesting contaminated water and food and by dermal contact, for example with consumer products (cosmetics, cleaning products, pesticides, etc.) $[16,17]$. Each pollutant is known to have unique features and physico-chemical properties which provide specific toxicological mechanisms of action to living organisms. Clofibric acid (CLA) for example, a compound used in pharmaceutics, is a common persistent pollutant in wastewaters, which can last up to several years in the aquatic environment and can affect the endocrine mechanisms of living organisms [18,19]. Exposure to POPs at high levels, may cause different health problems such as cardiovascular diseases, diabetes, endocrine disruption, birth defects, dysfunctional reproductive systems and cancers [8].

It is therefore evident that specific measures should be considered in order to prevent, reduce or eliminate these toxic pollutants from contaminated media. Given the increasing environmental concerns and legal constraints related to maximum acceptable concentrations of pollutants imposed on discharged effluents, new cost-effective alternative technologies should be developed. The conventional physical and chemical technologies (adsorption, absorption, ion-exchange, membrane processes, chemical precipitation) involve high energy consumption and high costs along with the possibility of toxic wastes generation or incomplete removal of pollutants [1]. In this attempt, the use of biomassbased sorbents, for example marine macroalgae [20], agricultural waste [9], including microorganisms for pollutants uptake has been demonstrated as being an environmentallyfriendly and cost-effective strategy for industrial effluents treatment. In spite of this, the 
bioremediation technology is not yet fully applied at large scale. New effort should be made to support microbial-based biosorption and bioaccumulation processes upscaling. It would be also very interesting for these methods to find some alternatives to enable recovery and reuse of compounds with commercial application from the resulted biomass [21] Using environmentally friendly alternatives (innovative compounds, innovative industrial processes) or pollution prevention by eliminating toxic compounds at the source will remain always the most preferred practices to attend a sustainable industrial production. Examples of innovative compounds are the nanomaterials that are increasingly studied in the last years. Graphene oxide combined with 2-aminobenzothiazole (GO-ABT) was used to recover the rare earth elements found in low concentrations in aqueous solutions. GO-ABT composites have been proved to be a promising adsorbent due to its capability to retain $100 \%$ of $\operatorname{Er}(\mathrm{III})$ even after ten regeneration cycles [22].

Biosorption and bioaccumulation processes involve a biological material (biosorbent) and a liquid phase (water) which contains the dissolved contaminant to be treated. Biosorption is a passive process that uses dead biomass where the toxic substances are adsorbed on the surface of biomass being the first step of bioaccumulation. Instead, bioaccumulation which is an active process, uses only living organisms where the contaminants are transported to the cell and further accumulated inside the cell [21,23]. Usually, the living organisms are not suitable for treating highly toxic organic/inorganic contaminants because the uptake of contaminants in large amounts could affect the metabolism of the organism and death may occur. This inconvenience is overloaded by inactive biomass [24]. Furthermore, the presence of multiple inorganic and organic persistent pollutants in industrial effluents usually occurs and significantly affects the bioremediation process, including the viability of the microbial biomass [25-27]. Advantages of using dead biomass instead of living biomass are that nutrients and energy sources are not required, better sorption capacity is provided, the processes are rapid, no toxic effects caused by contaminants are involved and the recovery of contaminants is easier allowing regeneration of the biomass. Besides these advantages, the dead microbial biomass can be reused through desorption process $[28,29]$. Bioaccumulation is considered a more complex and expensive process compared to biosorption $[1,21,23]$. At the end of its life cycle, the living and dead biomass loaded with metals that are considered micronutrients for plant development, can be applied to soils through composting [30].

There are many review studies that approach the biosorption and bioaccumulation processes using microbial biomass, among which persistent pollutants such as heavy metals are extensively analyzed $[4,23,31-34]$. The distinct environmental behavior, structure and properties of persistent organic pollutants compared to heavy metals led to the evaluation of the potential of microorganisms to remove these pollutants from the environmental compartments, in different studies. For example, Torres et al. [35] discussed about the removal of heavy metals and organic compounds such as antibiotics and dyes, which in fact are not included in the list of persistent organic pollutants. Gaur et al. [36] in their paper focused on the application of biodegradation/bioremediation for removing of persistent and non-persistent pesticides, PCBs and PAHs (as persistent organic pollutants) and pharmaceutical and personal care products from wastewater. In another review the potential of cold-adapted microorganisms to remove the POPs are presented, being highlighted in particular the enzymes involved in adaptation to cold conditions [37].

To obtain a more thorough perspective on the available scientific literature in the topic of interest, we conducted an analysis of the published papers in the last ten years, based on PubMed database (Figure 1). In case of the microbial remediation of heavy metals from wastewaters, the key words used were "microorganism heavy metals biosorption". The obtained results showed 93 published articles. To identify the published articles referring to POPs the search was performed using "microorganisms persistent organic pollutants (or each POPs name according to the Stockholm convention list) biodegradation" words. After a careful analysis, 167 articles were identified as being related to the keywords used. 


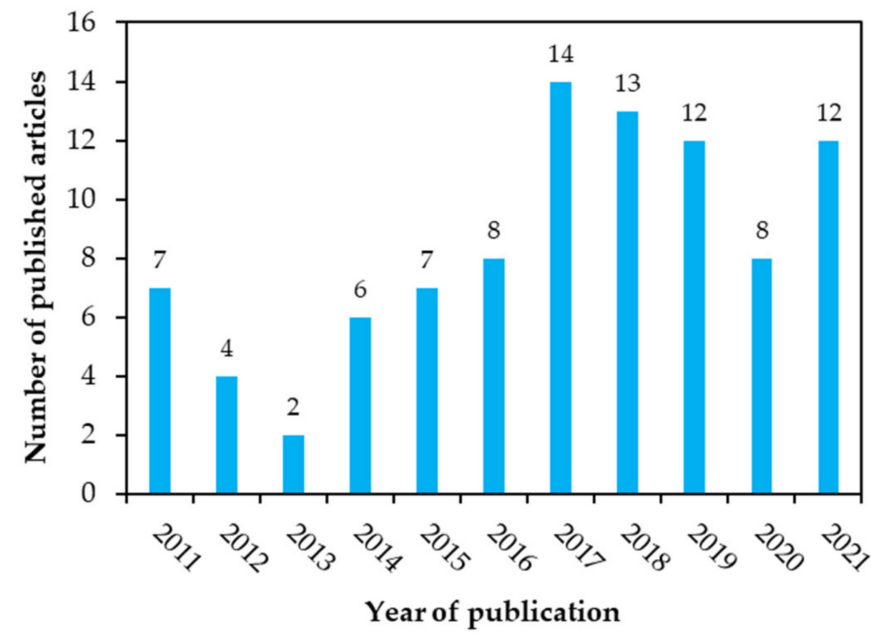

(a)

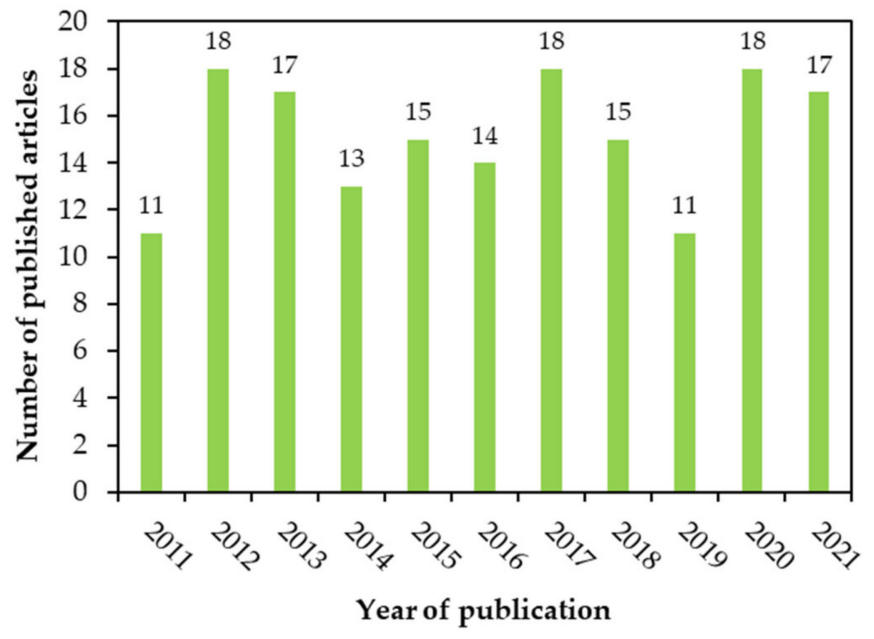

(b)

Figure 1. Number of published articles in international journals included in PubMed database: a summary of 10 years of publishing for (a) HMs biosorption by microorganisms and (b) POPs biodegradation by microorganisms.

In this framework and based on the available literature data, our paper reviews the main aspects related to: (i) the sources and the presence of HMs and POPs (listed in the Stockholm convention) in the environmental compartments; (ii) bioremediation of HMs and POPs contaminated waters by microorganisms: mechanisms, influencing factors and removal performance based on a large variety of microorganisms and under different operating conditions; (iii) key considerations and future perspectives for wastewater bioremediation scale-up considering life cycle assessment methodology. Knowing all of these aspects will enable controlling and performing of the process under industrial regime in order to be fully beneficial for the environment and society.

\section{Sources of Persistent Pollutants and Contamination}

\subsection{Heavy Metals}

Heavy metals (HMs) are naturally occurring constituents usually defined as elements with high atomic weight (greater than 40.04) and high density (larger than $\left.4-5 \mathrm{~g} \mathrm{~cm}^{-3}\right)$ [38,39]. HMs are generally classified into four categories: toxic heavy metals (e.g., arsenic, cadmium, lead, mercury); essential nutrients for living organism (nickel, zinc, cobalt, copper, chromium, iron, selenium); precious metals (e.g., silver, gold, platinum) and radionuclides (e.g., uranium, thorium, tellurium, thallium, bismuth). The essential inorganic nutrients perform some metabolic functions for maintaining normal human health, but in large quantities they may pose acute and chronic effects $[38,40]$. Due to their high degree of toxicity, arsenic $(\mathrm{As})$, lead $(\mathrm{Pb})$, mercury $(\mathrm{Hg})$ and cadmium $(\mathrm{Cd})$ are listed by the United States Agency for Toxic Substances and Disease Registry (ATSDR), amongst the top ten hazardous substances that pose the greatest threat to human health [41].

Water is the most natural resource necessary to sustain food production and its contamination depleting the quality of life [3]. Volcanic eruptions, natural forest fires and bedrock weathering are the main natural sources of heavy metals that alter the water sources quality [39]. A high amount of pollutants are being released in water from different industrial activities, especially during the discharge of industrial, municipal and agricultural wastewaters and sewage into rivers [26]. Phosphate rock processing as well as phosphate fertilizers use in agriculture are important pollution sources for surface waters [42]. So, the faulty control and management of industrial, municipal and agricultural effluents and sewage often can result in the transformation of receiving waters into inadequate resources for agricultural purposes (e.g., fishing and irrigation) [43]. HMs are found in different concentration in sewage sludge and industrial effluents that are finally discharged into water bodies. Once they have entered in the aquatic environment, 
HMs become available for accumulation in sediments and bioaccumulation in benthic organisms and finally in food chain. Since sediments are proper sink for heavy metals, their concentrations are higher in sediments and benthic fauna than in water [5,12]. For example, Algül and Beyhan [44] while investigating the quality of aquatic ecosystem in Lake Bafa (Turkey) found that the mean concentrations of heavy metals in the shallow sediments decreased in the following order: $\mathrm{Fe}>\mathrm{Mn}>\mathrm{Ni}>\mathrm{Cr}>\mathrm{Zn}>\mathrm{Cu}>\mathrm{Co}>\mathrm{Pb}>\mathrm{Cd}$. They concluded that $\mathrm{Cd}, \mathrm{Cr}, \mathrm{Cu}$, and particularly $\mathrm{Ni}$ may pose risks to the ecosystem of Lake Bafa and their high concentration are mainly caused by the use of pesticides and fertilizers, fuel combustion, releases of untreated wastewater from aquaculture facilities etc. [44]. Gabrielyan et al. [45] performed a research to investigate the distribution of heavy metals in the waters and sediments of the Voghji River (Armenia). It should be specified that Voghji River drains two mining regions. The investigation was based on data sets from period 2014-2016. The authors observed that Voghji River was most polluted with Mn, Co, Cu, $\mathrm{Zn}, \mathrm{Mo}, \mathrm{Cd}$, and $\mathrm{Pb}$, that were mainly released in water bodies from drainage water and wastewater of mining regions. Agoro et al. [26] provided a very complex study regarding the distribution of some selected heavy metals $(\mathrm{Cd}, \mathrm{Pb}, \mathrm{Cu}, \mathrm{Zn}$, and $\mathrm{Fe})$ during the various stages of treatment in three sewage treatment plants in the Eastern Cape Province (South Africa). The operation of the three sewage treatment plants revealed a slight pollution. The majority of the five metals were detected in sewage sludge ( $\mathrm{Zn}$ concentration was below the detection limit while $\mathrm{Cu}, \mathrm{Cd}$, and Fe were found in very low concentrations, below recommended limits). However, $\mathrm{Cd}$ was above the permissible level in all the samples considered (effluent, upstream and downstream samples).

$\mathrm{HMs}$ such as $\mathrm{Hg}, \mathrm{Pb}, \mathrm{Cd}, \mathrm{Cr}$ and As even in low concentration may affect plants development by inhibiting root growth, synthesis of proteins and enzymes, damage to plasma membrane, and thus reducing food supplies by significantly decreasing of crops amount [46,47]. For example, Fargašová [48] used Sinapis alba L. as a model plant to test the toxicity of $\mathrm{Cd}, \mathrm{Cu}, \mathrm{Pb}, \mathrm{Se}, \mathrm{Zn}$ on its development. The phytotoxicity test was performed in hydroponic solutions at different metal concentrations. Copper and selenium affect in a lower extent the development of plant, while $\mathrm{Pb}$ reduced strongly enough photosynthetic pigments production. The metals accumulated into the roots and cotyledons decreased in the following order: $\mathrm{Cd}>\mathrm{Zn}>\mathrm{Se}>\mathrm{Pb}>\mathrm{Cu}$ [48].

In this regard, European Water Framework Directive (WFD) 2000/60/EC was implemented and Directive 2013/39/EC defined environmental quality standards (EQS) for priority substances (including metals) to minimize the discharge of toxic compounds into all ground and surface water within EU Member states [5].

According to the European Environment Agency (EEA), 38\% of surface waters have a good chemical status, $46 \%$ do not have a good chemical status, while $16 \%$ provide an uncertain status in terms of water quality. A relatively low category of persistent pollutants is responsible for these results [49]. Of these, heavy metals, especially mercury, play an important role. Other metals with significant environmental impact are lead, nickel and cadmium.

Statistics on the contribution of various sectors of human activity to the contamination of aquatic environments with heavy metals in 2017 (Figure 2) showed that waste and wastewater management have a major contribution to water pollution with metals such as nickel (183 tons), lead (48.8 tons), arsenic (28.9 tons) and cadmium (8.55 tons), respectively, compared to other activities [50].

A significant source of heavy metals at international level is related to mining activities. Statistics from 2016 on the situation in Europe, indicated that 19\% of the impact on the environment is due to mining activities. Aquaculture also contributes to the impact of heavy metals on the aquatic environment, with a share of $14 \%$. According to the European Environment Agency, Europe's energy-producing industry contributes with 6\% to the impact of heavy metals on aquatic environments by exploiting the North Sea's oil resources and power plants on the continent [51]. 


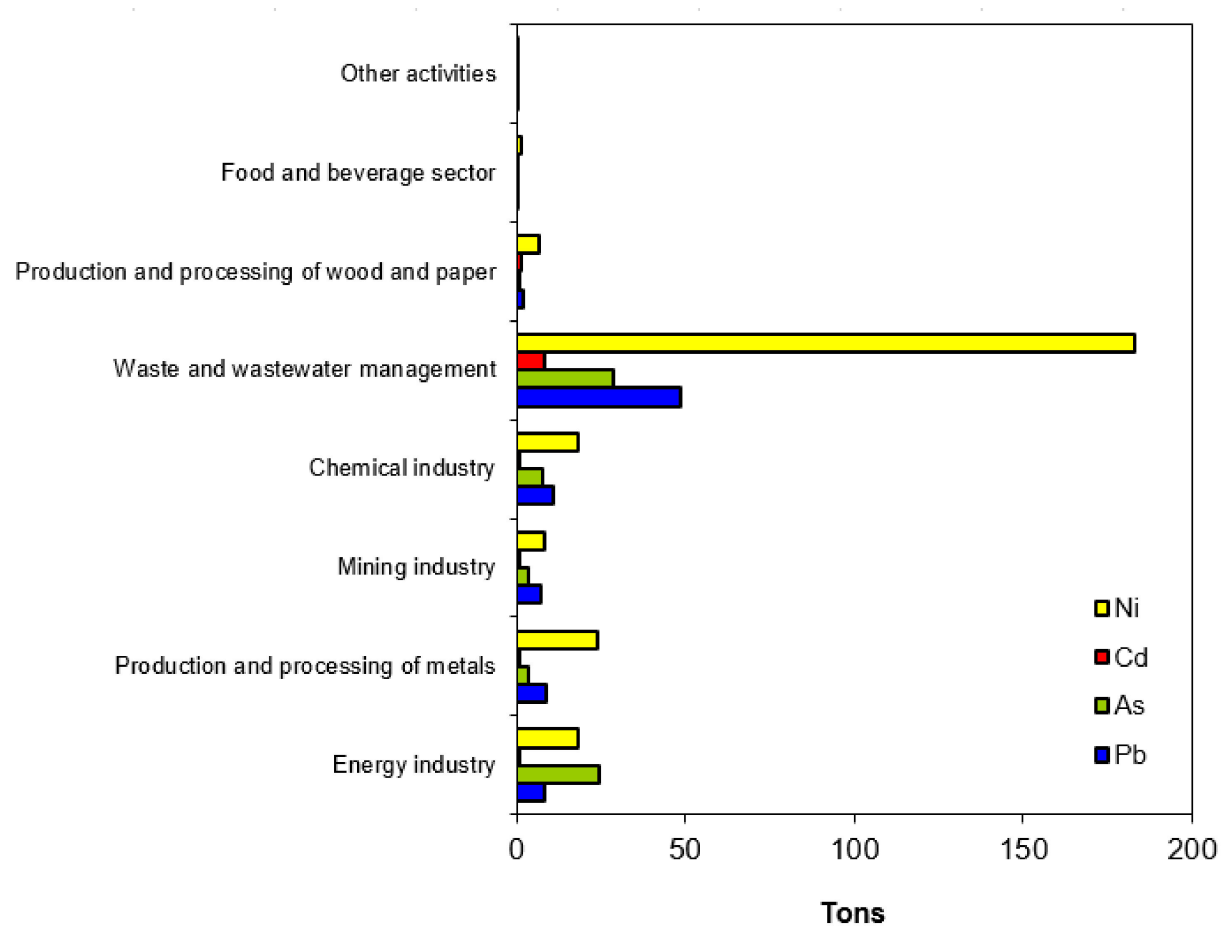

Figure 2. The contribution of various sectors of anthropogenic activity to the contamination of aquatic environments with heavy metals in 2017.

\subsection{Persistent Organic Pollutants (POPs)}

POPs are synthetic organic chemical compounds with a particular combination of physical and chemical properties that provide them some specific features. Thus, once they are released in the environment $[16,17]$ :

- They persist and remain unchanged in the environment for very long periods of time (many years);

- They are widely distributed throughout the environment (in soil, water and, mostly, in air);

- They accumulate in the fatty tissue of living organisms and are detected in higher amounts at upper-trophic levels in the food chain;

- They are toxic to both humans and wildlife.

POPs are grouped in three categories [16,52,53]: (i) pesticides: aldrin, chlordane, lindane, DDT, dieldrin, endrin, heptachlor, mirex, toxaphene, pentachlorophenol; (ii) industrial chemicals: hexachlorobenzene (HCB), polychlorinated biphenyls (PCBs) and (iii) unintended by-products: polychlorinated dibenzo- $p$-dioxins and polychlorinated dibenzofurans (PCDD/PCDF), PCBs, HCB, pentachlorobenzene, polyaromatic hydrocarbons (PAHs).

Due to their persistence in the environment, bioaccumulation/biomagnification in living organisms and associated hazard effects to biota, different global and regional conventions have been elaborated with the main purpose of eliminating or reducing emissions of POPs [10,54]. In this regard, the Stockholm Convention on Persistent Organic Pollutants initially addresses 12 priority POPs (the original 'dirty dozen') to be banned or used with restrictions, while the Protocol to the UN-ECE Convention on Long-range Transboundary Air Pollution (UN-ECE LRTAP) covers the Stockholm Convention POPs and other four POPs [10]. The original 'dirty dozen' included organochlorine insecticides, PCBs, PCDFs and HCB. In present, other 16 new POPs are ratified by Stockholm Convention which include some non-chlorinated compounds such as perfluorinated detergents and polybrominated diphenyl ethers-PBDEs [55]. For complete details please see the list on priority POPs at [56] and [57]. 
There are many pathways to release POPs into the environment. First of all, POPs such as pesticides are used in agriculture being released as a result of plant protection treatments especially from their use, transport, storage and disposal [58]. Agriculture soil is the main source of soil pollution where POPs may enter through intentional discharges, unintentional spillages or deposition from air. Plant foliage uptake of POPs from air makes it possible their transfer to plant, and subsequently to food or may remain in soil where other possibilities can occur: re-emission, surface and subsurface flow, leaching in groundwater or degradation in soil [59]. Through re-emission, agriculture soils became a source of POPs in atmosphere [60]. Since POPs are considered lipophilic compounds they are not very soluble in water, meaning that the degree of POPs transfer to water may be relatively low. A more reliable process could imply the transport of POPs from soil to surface or ground water especially in intense rainy periods [60]. However, the majority of POPs are directly or indirectly emitted in air from different sources (waste incineration, fuel combustion, forest fires, furnace plants, power and heating stations, chemical synthesis of chlorinated substances, volatilization from water surfaces and soil, etc.) [58,59]. Overall, deep ocean, deep soil and sediments are known to be the final sinks for POPs [61].

At European level, according to the European Pollutant Release and Transfer Register, between 2015 and 2017 period, different quantities of pesticides and industrial organic pollutants belonging to the POPs category were released into EU surface waters. These pollutants mainly arise from economic activities, waste and wastewater management, chemical industry, energy sector and production and processing of wood and paper. Pesticides such as aldrin, dieldrin and endosulfan and industrial chemicals such as hexachlorobutadiene, pentachlorophenol and bromodiphenyl ethers were the main categories of POPs released into surface waters. As can be seen from Figures 3 and 4, industrial chemicals and by-products compounds are released in larger quantities in surface waters compared to pesticides [50].

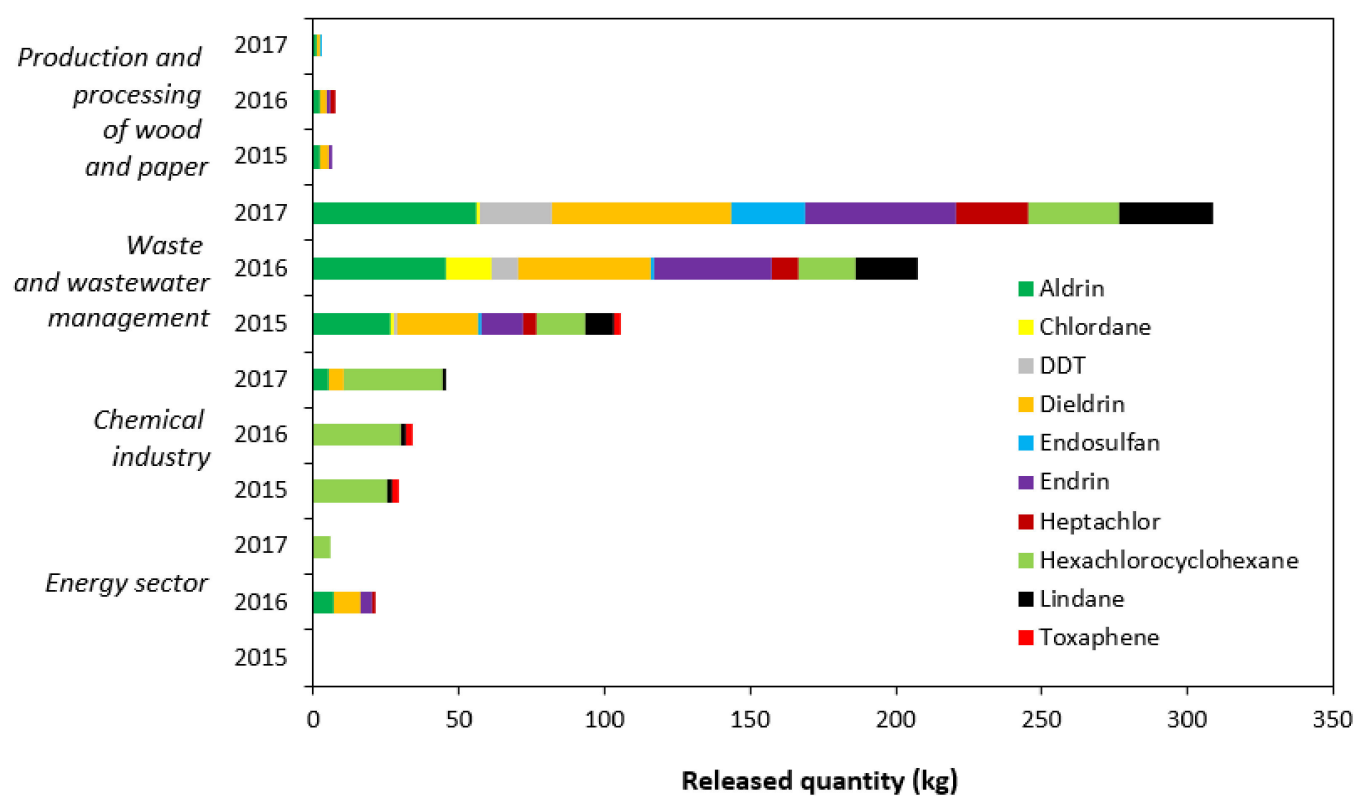

Figure 3. Pesticide emissions from various industrial activities in Europe's surface waters in the period 2015-2017. 


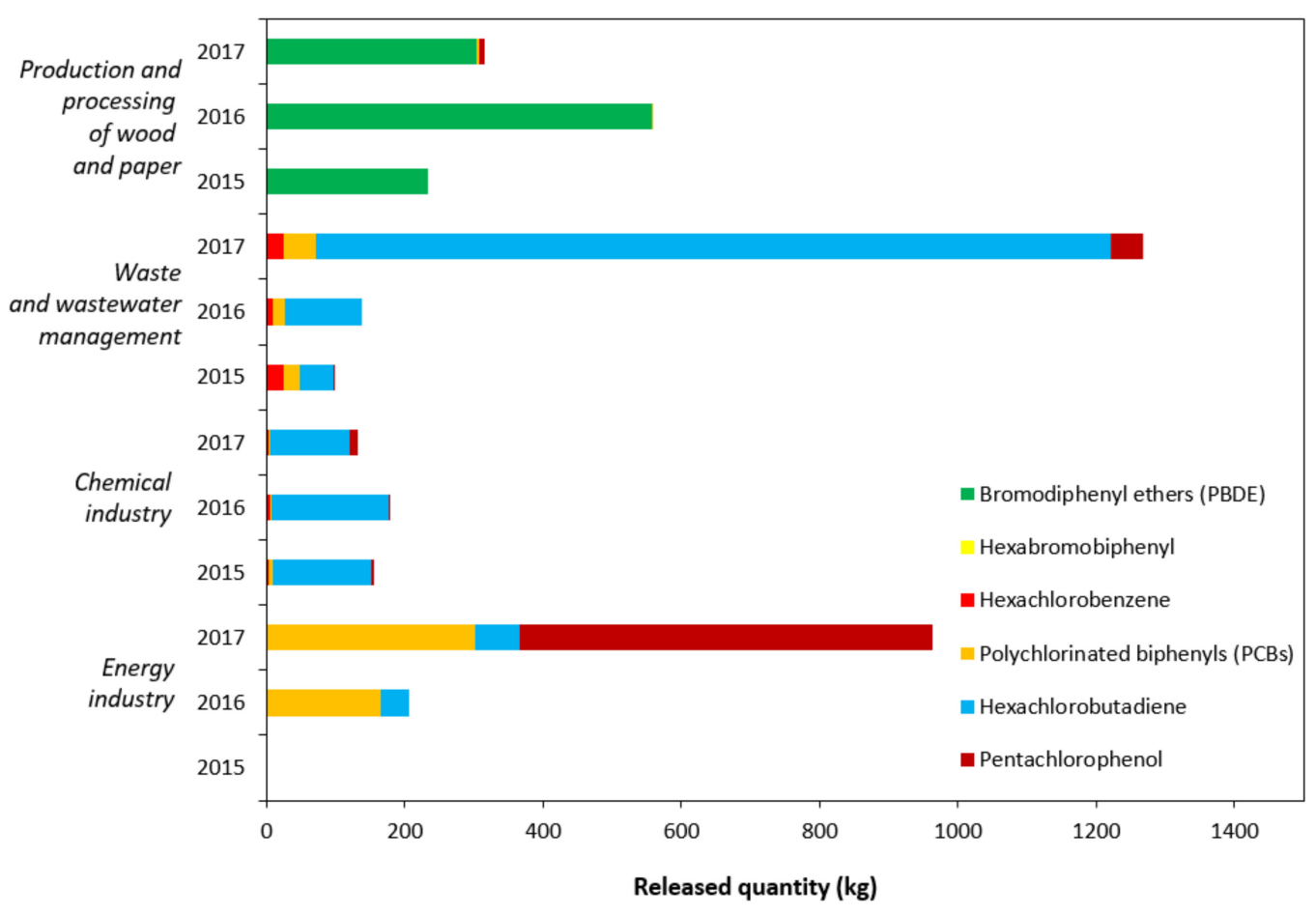

Figure 4. Emissions of industrial chemicals and by-products from various industrial activities in Europe's surface waters in the period 2015-2017.

\subsection{Transport and Routes of Persistent Pollutants in the Environment}

The release of pollutants into various environmental compartments (surface water, soil, groundwater and air) will lead to the subsequent transport of them from the point of emission to other components of the ecosystem, even in most isolated place on Earth like Artic Pole. As a consequence, the degree of pollutants accumulation will contribute to the exposure assessment of the population or flora and fauna existing in these compartments [62]. More precisely, persistent pollutants have the ability to enter and migrate along the food chain and increase their concentrations and retention times by a series of mechanisms denoted as biomagnification (or indirect bioaccumulation). For example, POPs are hydrophobic compounds with a high solubility in fats, thus accumulating in the adipose tissues of living organisms [63]. Heavy metals are elements that do bioaccumulate in living organisms causing changes at the cellular level [38]. These aspects attracted the attention of researchers to identify the transport routes and mechanism of pollutants between the environmental components and thus establish their cycle in the environment $[19,20]$ (Figure 5).

\section{Bioremediation of Heavy Metals Contaminated Wastewaters by Microorganisms}

\subsection{Mechanisms of Heavy Metals Removal by Microorganisms}

Although they have different advantages and disadvantages, most studies indicate a higher level of removal performance for heavy metals through the biosorption process, compared with bioaccumulation [31]. Biosorption has been shown to be generally a rapid process that takes place in a few hours, while the process of bioaccumulation could last from several days to several weeks. Also, performing both processes under the same operating conditions indicated a higher remediation capacity in the case of biosorption [34]. 


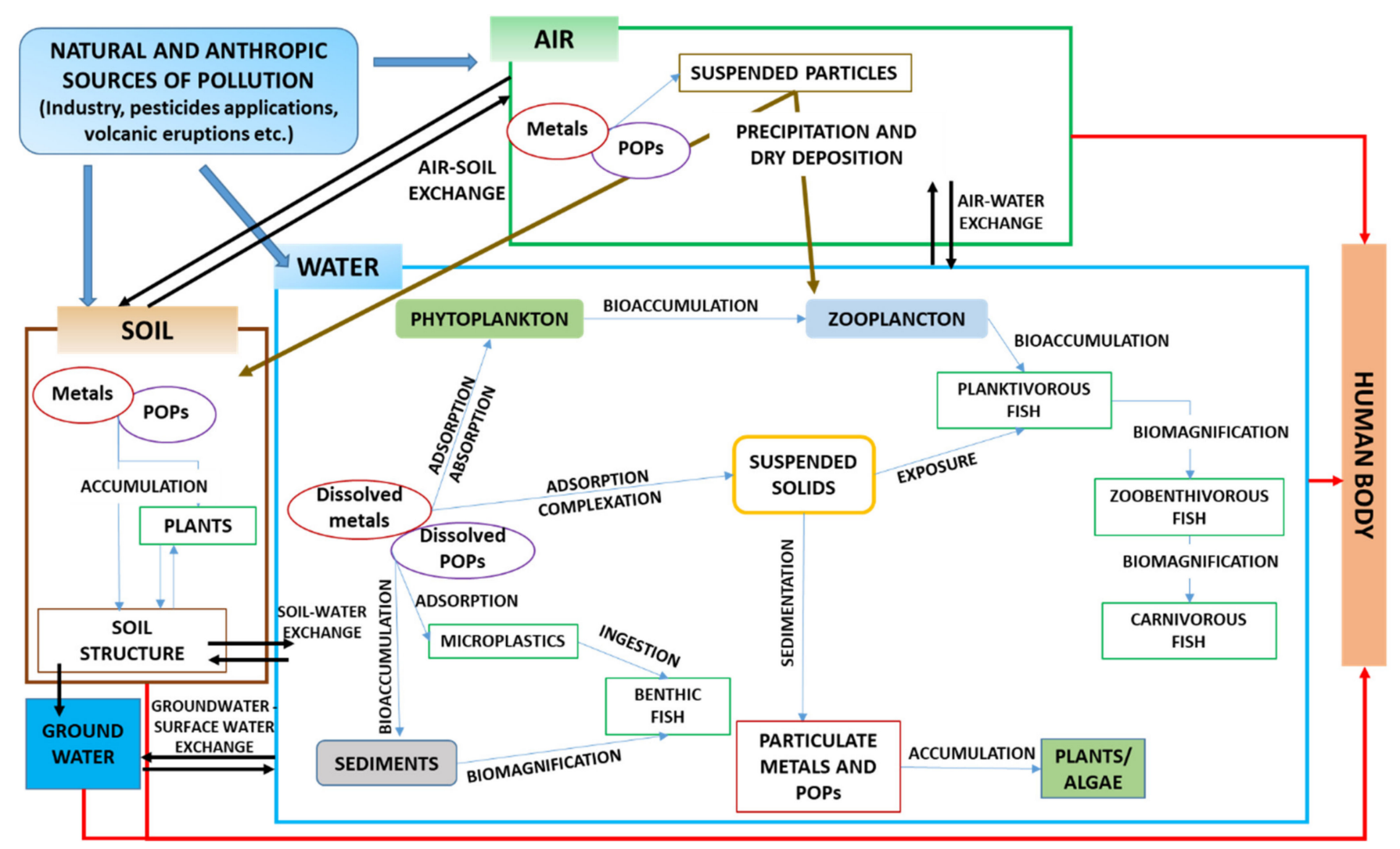

Figure 5. Transport and routes of persistent pollutants in the environment.

To achieve the maximum performance by microorganisms in the removal of heavy metals through the biosorption and bioaccumulation processes there are a number of important aspects to be attained. For example, certain metals such as cobalt, copper, manganese, iron and zinc $[33,64]$ have a role in the proper functioning of cellular microbial metabolism, while others such as mercury, cadmium and lead have no role in the proper conduct of microbial processes [64,65].

The development of microorganisms is achieved through the lag, exponential, stationary and declining phases [66]. The lag phase is the period of adaptation of viable microorganisms to new environmental conditions or external factors. At this stage, the cell adapts to external influence through the formation of growth enzymes and other intermediates with a role in cell development. Usually, as the concentration of the metal to which the microorganism is exposed increases, the lag phase increases, and the maximum tolerance index in the stationary growth phase decreases [67].

The process of bioaccumulation of heavy metals by microorganisms involves two main stages, the first being biosorption at the cell wall, and the second being the incorporation of the pollutant into intracellular structures by biotransformation and metabolic pathways based on the use of enzymes and the ATP transport system.

Biosorption takes place through the formation of extracellular bonds, a process that takes place very quickly. Therefore, the second stage is achieved by slow-evolving metabolic processes that take place by transporting metal ions from the membrane to the intracellular structures and forming bonds with them. Thus, the chemical structure of the cell wall plays an important role in the biosorption mechanism, with the specific functional groups depending on the type of microorganism used [31].

Biotransformation consists of reduction, oxidation or alkylation processes that have an important role in determining the creation of metal species with low toxic effect. Bioprecipitation is another process with important function by producing proteins such as metallothioneins and phytochelatins, which form complexes with metals [31]. Studies to 
date show that the main mechanism involved in the biosorption of a metal is ion exchange. Other elements and processes involved are van der Waals forces and complexation. Also, other mechanisms that can occur in both biosorption and bioaccumulation processes are associated with metal reduction, proton release, biomethylation, and chelation by ionic and covalent interaction $[32,68]$.

The response mechanism of the microorganism to the pollutant consists first in the generation of extracellular compounds with a role in metal adsorption and precipitation, and in the second stage the binding of metal ions to thiol-containing metabolites takes place, with the formation of complexes stored in vacuoles or other compartments from the cell [67]. Proteins and peptides such as metallothionein mediate hormones and redox signaling molecules in the metabolic responses of microorganisms in contact with heavy metals [69]. Glutathione (GSH), a sulfur-containing compound, also plays a role in the detoxification process [67].

The remediation of wastewaters loaded with heavy metals is usually ensured by the following main microbial mechanisms [4,31,70] (Figure 6):

- bioaccumulation (I),

- $\quad$ surface complexation (II),

- bioprecipitation (III),

- ion exchange (IV),

- electrostatic interactions $(\mathrm{V})$ and

- cell surface adsorption (VI).

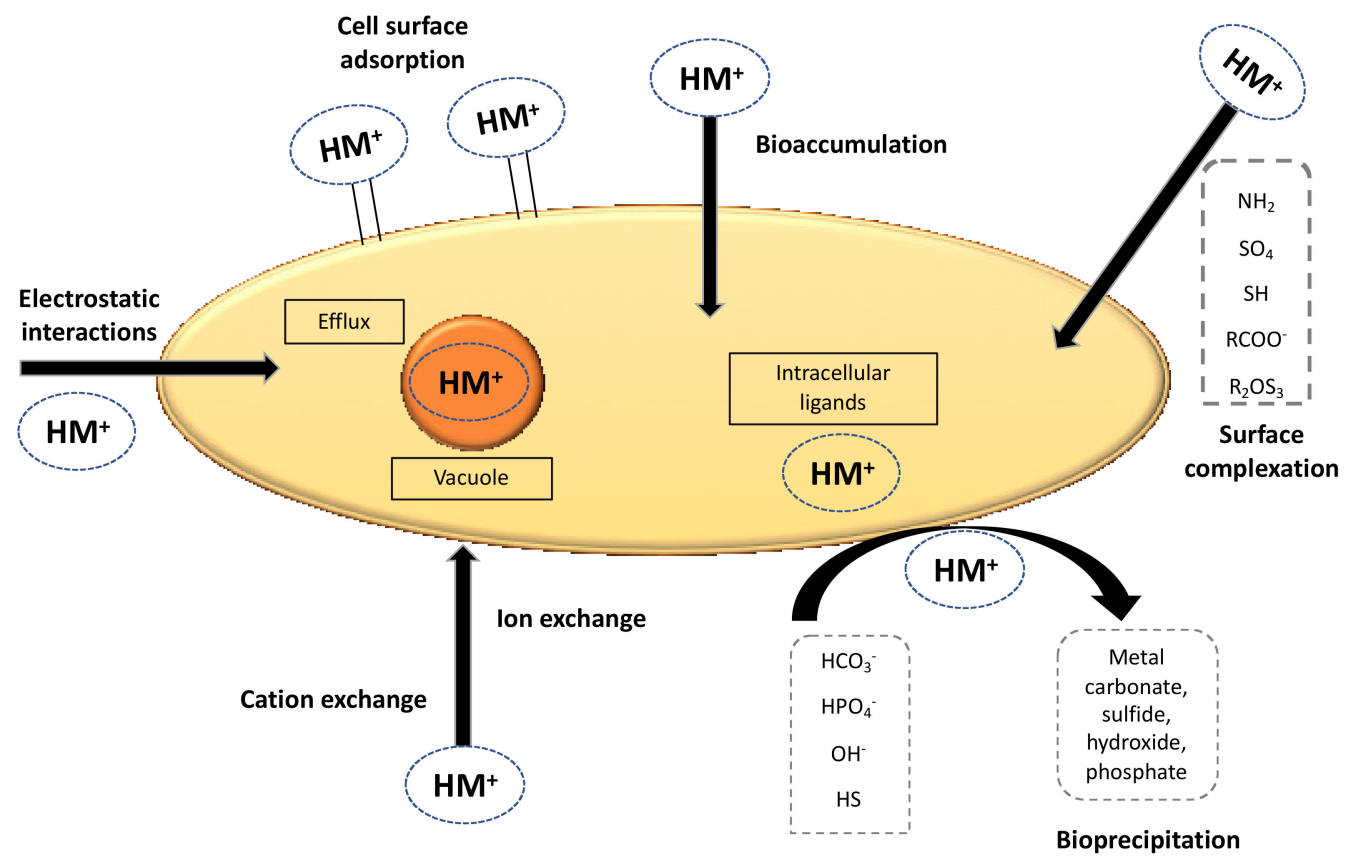

Figure 6. HMs removal strategy followed by microorganisms: the bioremediation mechanisms followed during the interaction between microorganism cell and HMs.

Very high potential for bioaccumulation or resistance to heavy metals has generally been identified in the case of microorganisms found in natural areas with extreme conditions or in the case of those naturally growing in contaminated sites. For example, a minimum inhibitory concentration of $4000 \mathrm{mg} / \mathrm{L}$ of cadmium was determined for Paecilomyces fungi specie. Also, minimum inhibitory concentration of $2000 \mathrm{mg} / \mathrm{L}$ was calculated in the case of Aspergillus versicolor and Terichoderma sp., while a value of $1000 \mathrm{mg} / \mathrm{L}$ of cadmium was identified for fungi species Microsporum sp., Cladosporium sp. and Aspergillus fumigates [71]. 
On the other hand, at concentrations of $20 \mathrm{mg} \mathrm{Cd}(\mathrm{II}) / \mathrm{L}$, and 10-20 $\mathrm{mg} \mathrm{Pb}(\mathrm{II}) / \mathrm{L}$, respectively, the amount of chlorophyll decreased in the case of the cyanobacterium Microcystis aeruginosa [72]. Inhibition of chlorophyll synthesis of microalgae following exposure to different concentrations of zinc has been demonstrated for many species, including those of the genera Chlorella and Scenedesmus [73].

Rhodococcus erythropolis isolated from a mining industry wastewater showed a tolerance to heavy metals in the range of $1-5 \mathrm{mg} / \mathrm{L}$ for $\mathrm{Pb}(\mathrm{II}), 1-50 \mathrm{mg} / \mathrm{L}$ for $\mathrm{Cu}(\mathrm{II}), 1-60 \mathrm{mg} / \mathrm{L}$ for $\mathrm{Cr}(\mathrm{VI}), 1-80 \mathrm{mg} / \mathrm{L}$ for $\mathrm{Zn}(\mathrm{II})$ and 1-70 mg/L for As(V), respectively [74]. A new bacterium, Halomonas sp., isolated from effluents of the electronics industry, has demonstrated the ability to remove Cd(II) concentrations of up to $100 \mathrm{mg} / \mathrm{L}$ [75].

Extremophilic bacteria and organisms generally have very well-developed mechanisms for removing and reducing heavy metals, as they depend on them to survive. Such bacteria have been used, for example, to remove Cd(II) ions. At a preliminary study level, the bacterium Brevundimonas sp. ZF12 generated a removal efficiency of $45 \%$, while a higher value was recorded for Enterobacter sp. ZF08, Bacillus sp. ZF10, Shewanella sp. ZF13, Rothia sp. ZF11, and respectively Rhodococcus sp. ZF05 [76]. Cr(VI) was removed after $72 \mathrm{~h}$ in a proportion of $74.2 \%$ by using the bacterium Oceanobacillus sp. W4, a bacterium isolated from soils polluted with this ion [77].

Trichoderma sp. is one of the fungal species with high tolerance to cadmium ions, resisting concentrations of up to $1000 \mathrm{mg} / \mathrm{L}$ [71]. However, certain differences were noticed in this interval in the influence of the evolution of fungal crops. Thus, in the case of $T$. simmonsii, increasing the $\mathrm{Cd}(\mathrm{II})$ concentration up to $125 \mathrm{~g} / \mathrm{L}$ determined a fungal growth increase of $46.1 \%$, and a decrease in the range of $125-500 \mathrm{mg} / \mathrm{L}$ [78]. Out of 41 species of filamentous fungi, isolated from the sediments of a river in Malaysia, only the specie Aspergillus niger was able to survive in cultivation conditions that include a $\mathrm{Pb}$ (II) concentration of $5000 \mathrm{mg} / \mathrm{L}$. At the same time, in the same study, tolerance of up to $1000 \mathrm{mg} / \mathrm{L}$ of $\mathrm{Cu}(\mathrm{II})$ was reported for the species Penicillium simplicissimum [79]. The development of Phanerochaete chrysosporium species was inhibited by $\mathrm{Cr}(\mathrm{VI})$ concentrations higher than $10 \mathrm{mg} / \mathrm{L}$, the bioaccumulation efficiency being reduced up to $23.82 \%$ [80]. Penicillium chrysogenum also showed a higher resistance to chromium, for concentrations up to $800 \mu \mathrm{g} / \mathrm{mL}$, compared to Aspergillus niger [81]. Tolerance at concentrations of $1200 \mathrm{mg} / \mathrm{L}$ were detected in the case of Aspergillus terreus and $1000 \mathrm{mg} / \mathrm{L}$ in Penicillium sp., Aspergillus lentulus and Fusarium solani [82]. For the species Aspergillus flavus, contact with $\mathrm{Hg}$ (II) ions slows the development of mycelium, but a tolerance to concentrations of up to $100 \mathrm{mg} / \mathrm{L}$ of $\mathrm{Hg}(\mathrm{II})$ has been detected [66].

Remediation of metal ions can be achieved by microorganisms and biosurfactants such as rhamnolipids, compounds that achieve metal complexation [83]. Also, the response of microorganisms can be manifested by reducing the amount of extracellular solution absorbed, as well as by increasing the amount of metal removed from the intracellular environment [71]. Due to the high toxicity of $\mathrm{Cr}(\mathrm{VI})$, which once released in the intracellular environment is transformed into the $\mathrm{Cr}(\mathrm{V})$ radical which has a high instability and causes the appearance of reactive oxygen species (ROS) - generating further DNA degradationmicroorganisms have adapted to extracellular reduction of $\mathrm{Cr}$ (VI) to $\mathrm{Cr}$ (III) form [84].

To reduce the mobility of heavy metals in wastewater, changing the oxidation state of the metal is often necessary through physical and/or chemical processes to obtain fewer toxic forms of the pollutant and more soluble or easy to remove. Microorganisms also have the ability to reduce the ionic forms of metals. Thus, they become easier to integrate into the cellular structures of microorganism. Geobacter species can transform U(VI) into the less soluble U(IV) form [69]. Also, the Cr(VI) species is usually reduced to the less toxic form $\mathrm{Cr}(\mathrm{III})$. In comparison with the conventional methods for reducing $\mathrm{Cr}(\mathrm{VI})$, that require a high amount of chemicals and a high level of energy, the use of microorganisms is considered to be less expensive and more sustainable. Also, in some cases, removal may be more effective in multi-metallic solutions [85]. Results of different studies have shown that for the reduction of $\mathrm{Cr}(\mathrm{VI})$ the optimal $\mathrm{pH}$ has a value of 7-8 [86]. $\mathrm{Cr}$ (III) has 
a slower diffusion across the cell membrane than $\mathrm{Cr}(\mathrm{VI})$, but certain complexes of $\mathrm{Cr}(\mathrm{V})$ and $\mathrm{Cr}(\mathrm{III})$ ions can penetrate more easily into the intracellular environment and cause cell damage. $\mathrm{Cr}(\mathrm{V})$ species can occur by reduction of $\mathrm{Cr}(\mathrm{VI})$ ions the activity of microbial compounds such as cysteine, glutathione, riboflavin or ascorbic acid and is extremely toxic. $\mathrm{Cr}(\mathrm{V})$ causes DNA damage and mutations in bacterial chromosomes [87]. To determine the mechanism involved in the process of removal of $\mathrm{Cr}(\mathrm{VI})$ by the bacterium Oceanobacillus $\mathrm{sp}$. W4, the role of electron donors acetate, lactose, NADH, glucose, formate, glycerin and citrate was analyzed. The results indicated that glycerin had the most significant role, followed by NADH and glucose. On the other hand, lactose inhibited the reduction process [77].

The ways of adaptation and protection of microalgae against the toxic effect of heavy metals involve processes of chelation, exclusion, immobilization and genetic regulation [32]. The integration of metal ions in the cellular metabolism of microalgae involves the formation of complexes between metals and proteins, separation into vacuoles, synthesis of phytochelatins and antioxidant enzymes [32,88]. Phytochelatins are low molecular weight sulfhydryl compounds with which the metal forms complexes with a role in homeostasis and detoxification of the metal. Increasing the concentration of $\mathrm{Cd}(\mathrm{II})$ for example, led to a proportional increase in sulfihydryl (-SH) groups [89]. As for the antioxidant compounds used by microalgae, they can be enzymatic (catalase, ascorbate peroxidase, superoxide dismutase, peroxidase and glutathione reductase) and non-enzymatic (cysteine, ascorbic acid, carotenoids, proline and glutathione) [32]. Also, another method of detoxifying the microalgal cell is to pour the metal back into the effluent [34].

Extracellular polymeric substances (SPEs), which are compounds synthesized by microbial organisms, also have an important role in the bioremediation processes. Their structure is formed by proteins and polysaccharides that have functional groups such as hydroxyl, carboxyl and phosphoric amines with a role in forming bonds with metal ions. Analysis of the activity of extracellular polymeric substances (SPEs) synthesized by the freshwater microalga Chlorella pyrenoidosa on inorganic arsenic indicated that the interaction between them and the metal ion is achieved by the C-O-H, C-O-C and $-\mathrm{NH}_{2}$ functional groups of tyrosine and polysaccharide constituents [90]. The algal cell wall is mainly composed of cellulose, but also contains other lipids, polysaccharides, and proteins, and has an overall negative charge on the cell surface. Functional groups with a role in metal ion binding are represented by hydroxyl, carbonyl, carboxyl, phosphate, amino and sulfhydryl groups, groups that determine the negative electrical charge of the cell wall. Bioaccumulation for the removal of heavy metals using microalgae was first suggested in 1957 [91]. Cell wall composition, and implicitly the type of chemical structures available for the metal ions binding is highly influenced by the parameters applied in growing the living organism. Deprivation of microalgae from the necessary light conditions determined the absence of carboxyl groups, and the lack of the necessary amount of nitrogen generated a higher number of carbohydrate and amino groups in the case of tests performed with Chlorella vulgaris. Furthermore, a reduced amount of nitrogen generated a higher biosorption capacity when microalgae provided a reduced amount of nitrogen $(11.9 \mathrm{mg} / \mathrm{g})$. This is due to the deacetylation amino groups. Metals such as $\mathrm{Ca}, \mathrm{Fe}$ and $\mathrm{Mg}$ are used by the microalgae for its development, while in the case of $\mathrm{Cd}$, the results in the literature differ towards its effect and beneficial or harmful concentrations. Copper in general has shown harmful activity on the electron transport of photosystem I and the modification of PSII [73]. Manganese also has an important role in the metabolism of microalgae having a function in the water cleavage reaction in the photosynthesis process, but zinc has an inhibitory role on chlorophyll synthesis [73].

The cell wall of bacteria has in its structure compounds such as galacturonic acid and teicoic acid which have active functional groups with a role in binding metal ions. Characteristic functional groups and extracellular polysaccharides, which also play a role in the biosorption process, differ depending on the type of bacterium and the culture conditions. Thus, in the case of gram-positive bacteria, phosphoryl and hydroxyl groups 
become active for heavy metal cations under alkaline conditions, while gram-negative bacteria have phosphate groups in the structure of lipopolysaccharides and phospholipids. Other functional groups involved are amino and carboxyl groups [31,76].

Also, the response mechanism of the bacterial cell to metal ions can be expressed by complexation and precipitation processes. The accumulation of the cadmium, zinc, copper, mercury and calcium using the species Pseudomonas syringae was achieved for example by complexation. Precipitation of metals can be achieved through acids such as $\mathrm{HPO}_{4}{ }^{2-}$ produced by Citrobacter sp. and $\mathrm{H}_{2} \mathrm{~S}$ generated by sulfate-reducing bacteria [31]. An important role in the metal ions uptake is therefore ensured by the polysaccharides forming the slippery layer on the outside of the cell wall, as well as other extracellular polymeric substances (SPE) that include lipids, proteins, nucleic acids and carbohydrates. These have the role of stopping the penetration of metals and other harmful external substances or radicals into the intracellular environment [33].

Remediation of heavy metals by bioaccumulation facilitated by bacteria can be achieved mainly by integrating the metal in small amounts into cellular metabolism and by detoxifying excess amounts of metal. $\mathrm{Cr}(\mathrm{VI})$ ions can enter the intracellular environment through the sulfate ion channel because the sulfate ion and chromate ion have a similar structure. At the same time, the action of microorganisms on metals consists in reduction or alkylation processes. The reduction of the metal ion $\mathrm{Hg}$ (II) to the less toxic form $\mathrm{Hg}^{0}$ involves the enzymatic transformation facilitated by mercury reductase [31]. Rhamnolipids play an important role in the resistance mechanism of P. aeruginosa bacteria, which are synthesized in the late stationary growth phase $(96 \mathrm{~h})$.

Cadmium resistance of gram-positive bacteria is facilitated by the ATPase which plays a role in cadmium transport, while for Gram-negative bacteria the Czc system is involved. Studies have also identified a higher incidence of plasmids, especially in bacteria contaminated with heavy metals. The czcABC gene is also involved in activating processes that ensure the resistance of bacteria to heavy metals such as $\mathrm{Zn}, \mathrm{Cd}$ and $\mathrm{Co}$. This gene has a role in the synthesis of compounds that transport metal ions outside the cellular environment [83].

The structure of the fungal cell wall has a significant influence in the metal removal processes. Its composition includes mannan, glucan and galactan in its outer layer and chitin, cellulose or non-cellulose glucan in its inner layer. The chemical composition of the cell wall also varies depending on the type of fungus. Thus, the cell wall structure of the genus Aspergillus lacks chitosan, while Rhizopus arrhizus contains more chitin, and Saccharomyces cerevisiae has a composition based on the manan-glucan complex and a chitin content of only 1\% [92]. Mushroom-specific compounds and structures such as phosphates, polysaccharides, chitin-chitosan complex and glucuronic acid are involved in ion exchange processes that ensure the binding of metals [33]. Starch, amino and hydroxyl groups are the functional groups present in chitin and chitosan compounds with a demonstrated function in removing heavy metals from wastewater [31]. In the case of certain metals, they are reduced by various specific mechanisms. Thus, the proteins $\mathrm{Ars} C$ and glutathione reduce arsenate to arsenite [93].

\subsection{Factors Affecting Microbial Remediation of Heavy Metals in Wastewaters}

In order to obtain maximum metal removal performances in the application of microorganisms as biosorbents, the physico-chemical factors and their effect should be understood and carefully analyzed. Optimization of these parameters leads to the identification of the values that can generate the highest removal performances.

The $\mathrm{pH}$ value is an extremely important factor that influences the biosorption and bioaccumulation processes having an effect on the complexation of organic and inorganic ligands, the chemical composition of metal solutions, as well as on redox, hydrolysis and precipitation reactions [68]. Studies have shown generally that the optimal $\mathrm{pH}$ values for the proper development of the biosorption process of metal ions through microorganisms ranges from 3 to 6 values [76]. 
Usually, for the removal of $\mathrm{Cr}(\mathrm{VI})$, the maximum efficiency is obtained at $\mathrm{pH} 2$, but this $\mathrm{pH}$ value can be destructive for the microbial cell [85]. Various forms of chromium can occur depending on the $\mathrm{pH}$. Thus, $\mathrm{HCrO}_{4}$ form of chromium can be found at $\mathrm{pH} 1$, where it is predominant and at $\mathrm{pH}$ 6. Furthermore, $\mathrm{Cr}_{2} \mathrm{O}_{7}{ }^{2-}$ and $\mathrm{CrO}_{4}{ }^{2}$ have been identified starting with $\mathrm{pH} 6$ and above [74,94]. In the case of $\mathrm{Pb}(\mathrm{II})$ ions, at a $\mathrm{pH}$ lower than 2 the protonation of the functional groups takes place and therefore the efficiency of metal removal decreases.

At the same time, the involvement of the functional groups at the cell wall level in binding of metal ions depends on the $\mathrm{pH}$. Thus, in the $\mathrm{pH}$ range $2-5$, the carboxyl group is usually activated, and in the range 5-9 both the carboxyl and the phosphate groups are involved. The development of the biosorption process also depends on the properties of the metal: ionic radius, oxidation state and molecular mass [68].

Another important aspect is the influence of other metallic or non-metallic ions on the development of the microorganism remediation process. Understanding it has a major role in treating industrial effluents in which various metallic and ionic species are found. The mechanical strength and declining stability of biomass as it is reused in sorption-desorption cycles are also problems that require finding solutions to enable high-scale application [68]. Eluent selection is of major importance so as to avoid the degradation of functional groups in the biosorbent and to ensure an efficient regeneration [95].

Certain ions can influence the evolution of the process of removing heavy metals by bioaccumulation. Reductase involved in the mechanism of $\mathrm{Hg}$ (II) uptake in Pseudomonas sp. B50A, for example, is partially inhibited by $\mathrm{Ca}(\mathrm{II}), \mathrm{K}(\mathrm{I})$ and $\mathrm{Cu}(\mathrm{II})$ ions. However, other ions such as $\mathrm{Sn}(\mathrm{II}), \mathrm{Cd}(\mathrm{II}), \mathrm{NH}_{4}(\mathrm{I}), \mathrm{Ni}(\mathrm{II})$ and $\mathrm{Ba}(\mathrm{II})$ do not influence the enzyme activity [96]. The addition of a $1 \mathrm{mM} \mathrm{Cu}$ (II) concentration increased the rate of reduction of $\mathrm{Cr}(\mathrm{VI})$ ions to $\mathrm{Cr}(\mathrm{III})$ to a maximum of $73 \%$. However, the presence of cadmium, zinc, cobalt and nickel determines a decrease in the reduction process [86]. Also, the remediation process may have a different duration for mono-metallic and multi-metallic solutions. Thus, the equilibrium of the sorption process in the case of bacterial strains isolated from the sediments of a polluted stream, was reached in the first $4 \mathrm{~h}$ for the single metal solution, while in the case of the multi-metal solution $5 \mathrm{~h}$ were required [97].

The active or inactive form of the bacterium, as well as the development stage of the used organism influences as well the heavy metals sorption process. In the case of Acinetobacter junii, the logarithmic phase generated the highest sorption capacity $(22.22 \mathrm{mg} / \mathrm{g})$ of $\mathrm{Cr}(\mathrm{VI})$ ions, followed by the values obtained for the stationary phase $(13.88 \mathrm{mg} / \mathrm{g})$, respectively the non-viable form $(6.94 \mathrm{mg} / \mathrm{g})$ [98]. The removal capacity of $\mathrm{Cd}$ (II) ions using Bacillus cereus was higher in the non-viable form, $31.95 \mathrm{mg} / \mathrm{g}$ compared to the viable one, $24.01 \mathrm{mg} / \mathrm{g}$, only $20 \%$ of the bioaccumulation process taking place based on intracellular mechanism [99]. In another study that applied the Bacillus cereus specie as a biosorbent, the active form generated a better capacity than the inactive form at low concentrations of $\mathrm{Cd}$ (II) [100]. The removal of $\mathrm{Pb}$ (II) ions using vegetative cells, decaying cells and spores was analyzed by applying the bacterium Bacillus coagulans, and the results obtained indicated the highest removal capacity in the case of the vegetative cell [101].

The application of high temperatures $\left(30-45^{\circ} \mathrm{C}\right)$ in the biosorption process causes an increase in metabolic activity of viable microorganisms and thus, implicitly, in the removal efficiency of metals [102]. In the case of applying non-viable microbial forms, the same range of temperature values determines an increase in the available binding sites on the surface of the biosorbent and thus, higher metal uptake. Temperatures above optimum level however, lead to the disintegration of the cell wall functional groups and determines the decrease of metal removal capacity [103]. Identifying the optimal conditions of the experimental parameters is very important to obtain maximum efficiencies in the biosorption process. Values of temperature and stirring speed greater than optimal ones, may cause, for example, the degradation of fungal hyphae [104]. 
The level of agitation is another factor that must be considered. Optimum value will determine higher metal uptake performance due to the fact that the agitation of the metal solution and the biosorbent facilitates their uniform distribution.

Metal concentration is another important influencing factor in the microbial biosorption or bioaccumulation processes. A higher metal ions concentration leads to a quicker saturation rate of the biosorbent. Also, when living biomass is concerned, the minimum inhibitory concentration must be known, to prevent the loss of viable microorganisms.

Even in the case of metals with metabolic function, quantities that exceed the tolerated limits of microorganisms cause disruption of cellular functions and degradation of components such as cell membrane and DNA structure. Thus, some microorganisms are very resistant to the influence of heavy metals, while others may be sensitive, even at very low concentrations. This depends on the species of microorganism, respectively metal, as well as on external conditions such as $\mathrm{pH}$, temperature, the presence of other ions and electron-yielding functional groups. The tolerance of microorganisms to heavy metals can be found by calculating the tolerance index (TI), respectively the minimum inhibitory concentration (MIC) [71]. The minimum inhibitory concentration represents the lowest pollutant concentration that inhibits the development of the microorganisms [85].

The tolerance index can be obtained based on the following equation [67]:

Tolerance Index = (Hyphae growth of fungi grown in the presence of metals)/(Hyphae growth of control fungi)

Biosorbent dose and cell concentration in biosorption, respectively bioaccumulation processes represent other significant factors influencing metal uptake. Thus, metal removal usually increases with the increasing biosorbent dose or cell concentration up to a specific value, after which overlapping and aggregation of available binding groups can occur [105].

\subsection{Heavy Metals Removal Performance}

Most of the available studies have applied microorganisms for metal removal from wastewaters in batch mode, especially in single metal systems. Research has shown that the adsorption capacity decreases in multimetal systems in comparison with single metal ones, at least for the same applied contact time. Real effluents contain usually more than one metal ion. Therefore, both single metal and multimetal solutions are important to be analyzed in batch mode.

Microalga Botryococcus sp. has been tested for the removal of arsenic, chromium, copper and cadmium from industrial wastewater with efficiencies of $45 \%$ for copper, $94 \%$ for chromium, respectively values less than $10 \%$ for cadmium and arsenic [106]. Scenedesmus obtusus microalgae grown in a phosphorus-enriched medium in concentrations of $0,20,40,80,160$ and $320 \mathrm{mg} \mathrm{L}^{-1}$, respectively, was applied as a non-viable form to remove $\mathrm{Hg}(\mathrm{II})$ ions on a laboratory scale. The highest adsorption capacity was identified for biomass obtained by culturing in $\mathrm{P}$ concentration of $80 \mathrm{mg} \mathrm{L}^{-1}$, but the highest growth rate of microalgae biomass was obtained at a P concentration of $160 \mathrm{mg} \mathrm{L}^{-1}$ [107]. Also, a difference in the removal capacity of metals was noticed between autoflocculating and non-flocculating microalgae. Thus, the removal of $\mathrm{Cd}(\mathrm{II})$ ions was performed with a higher efficiency $(93.39 \%)$ by Scenedesmus obliquus with autoflocculation capacity, in the range of $\mathrm{pH}$ values 3-6 and a biomass dose of $0.8 \mathrm{~g} / \mathrm{L}$ [108].

Several types of sorbents obtained based on the microalga Scenedesmus quadricauda were used to determine the adsorption capacity, respectively absorption of $\mathrm{Cr}(\mathrm{VI})$ ions. The microalgal biosorbent in powder form had a $\mathrm{Cr}(\mathrm{VI})$ removal efficiency of $96.62 \%$, approximately double then that of the microalgal pellets used. At the same time, the application of chemical treatments to the inactive biomass did not facilitate the increase of the efficiency of the biosorption process, and in the case of using microalgae in active form, a significantly lower uptake performance was generated than in the case of the inactive organism, $67.03 \%$, value obtained after 12 days of bioaccumulation. Biocarbon obtained by pyrolysis at $500{ }^{\circ} \mathrm{C}$ demonstrated the total removal of the target metal [28]. 
The adsorption capacity of bacterial-based biosorbents was also tested by applying natural effluent and real wastewater tests. Removal of some heavy metals ions from wastewater using a concentration of $0.2 \mathrm{~g} / \mathrm{L}$ biosorbent, temperature $25^{\circ} \mathrm{C}$, actual effluent $\mathrm{pH}$ value and $0.5 \mathrm{M} \mathrm{HNO}_{3}$ as eluent, was analyzed from a water collected from the confluence between the effluent of a wastewater treatment plant and domestic wastewater from China. The results indicated removal efficiencies of $70.6 \%, 89.6 \%$ and $94.8 \%$, for $\mathrm{Cu}(\mathrm{II}), \mathrm{Cd}(\mathrm{II})$, respectively $\mathrm{Pb}(\mathrm{II})$, but for $\mathrm{Ni}(\mathrm{II})$ and $\mathrm{Cr}(\mathrm{IV})$ the identified values were less than $10 \%$ [109]. Table 1 synthesizes several significant results identified in recent scientific literature on heavy metals removal performance using microbial living biomass.

Table 1. Heavy metals removal by microbial living biomass.

\begin{tabular}{|c|c|c|c|c|}
\hline Microorganism & Metal & Optimal Conditions & $\begin{array}{l}\text { Efficiency/Sorption } \\
\text { Capacity }\end{array}$ & Ref. \\
\hline \multicolumn{5}{|c|}{ MICROALGAE } \\
\hline \multirow{2}{*}{$\begin{array}{l}\text { Chlorella } \\
\text { vulgaris }\end{array}$} & \multirow{2}{*}{$\mathrm{Hg}(\mathrm{II})$} & \multirow{2}{*}{$\mathrm{C}_{\mathrm{i}}=10 \mu \mathrm{g} / \mathrm{L}, \mathrm{pH}=5.0 \pm 0.2, \mathrm{t}=5$ days } & $62.85 \%$ & \multirow{2}{*}{ [110] } \\
\hline & & & - & \\
\hline \multirow{2}{*}{ Phacus sp. } & \multirow{2}{*}{$\mathrm{Pb}(\mathrm{II})$} & \multirow{2}{*}{$\begin{array}{c}\mathrm{C}_{\mathrm{i}}=1 \mathrm{mg} / \mathrm{L}, 10 \%(v / v) \text { Phacus strain inoculum, } \\
\text { culture concentration }=1.03 \times 10^{6} \text { cells } / \mathrm{mL} \text {, room } \\
\text { temperature }\left(25^{\circ} \mathrm{C}\right), \mathrm{t}=1 \text { week }\end{array}$} & $\begin{array}{c}96.8 \% \\
-\end{array}$ & \multirow{2}{*}[111]{} \\
\hline & & & $3.90 \pm 0.09 \mathrm{mg} / \mathrm{g}$ & \\
\hline \multirow[t]{2}{*}{ Phacus sp. } & \multirow[t]{2}{*}{$\mathrm{Al}(\mathrm{II})$} & \multirow{2}{*}{$\begin{array}{c}\mathrm{C}_{\mathrm{i}}=9.94 \mathrm{mg} / \mathrm{L}, 10 \%(v / v) \text { Phacus strain inoculum, } \\
\text { culture concentration }=1.03 \times 10^{6} \text { cells } / \mathrm{mL}, \\
\mathrm{T}=25^{\circ} \mathrm{C}, \mathrm{t}=1 \text { week }\end{array}$} & $19 \%$ & \multirow[t]{2}{*}[111]{} \\
\hline & & & $12.32 \pm 0.13 \mathrm{mg} / \mathrm{g}$ & \\
\hline \multirow[t]{2}{*}{ Phacus sp. } & \multirow[t]{2}{*}{$\mathrm{Ni}(\mathrm{II})$} & \multirow{2}{*}{$\begin{array}{c}\mathrm{C}_{\mathrm{i}}=9.94 \mathrm{mg} / \mathrm{L}, 10 \%(v / v) \text { Phacus strain inoculum, } \\
\text { culture concentration }=1.03 \times 10^{6} \text { cells } / \mathrm{mL} \text {, room } \\
\text { temperature }\left(25^{\circ} \mathrm{C}\right), \mathrm{t}=1 \text { week }\end{array}$} & $75.17 \%$ & \multirow[t]{2}{*}[111]{} \\
\hline & & & $30.8 \pm 0.16 \mathrm{mg} / \mathrm{g}$ & \\
\hline \multicolumn{5}{|c|}{ BACTERIA } \\
\hline \multirow{2}{*}{ Pseudomonas sp. B50A } & \multirow{2}{*}{$\operatorname{Hg}(\mathrm{II})$} & \multirow{2}{*}{$\begin{array}{c}\mathrm{C}_{\mathrm{i}}=350 \mathrm{mM} ; \text { Cell concentration }=2 \times 10^{7} \mathrm{CFU} \\
\mathrm{mL}^{-1}, \mathrm{~T}=30^{\circ} \mathrm{C} ; \mathrm{pH}=8 ; \mathrm{t}=8 \mathrm{~h}\end{array}$} & $93 \%$ & \multirow{2}{*}{ [96] } \\
\hline & & & - & \\
\hline \multirow{2}{*}{ Stenotrophomonas sp. } & \multirow{6}{*}{$\mathrm{Pb}(\mathrm{II})$} & \multirow{2}{*}{$\begin{array}{l}\mathrm{C}_{\mathrm{i}}=200 \mathrm{mg} / \mathrm{L} ; \mathrm{pH}=7 ; \mathrm{T}=37^{\circ} \mathrm{C} ; \\
\text { Agitation speed }(\mathrm{rpm})=150\end{array}$} & $85.3 \%$ & \multirow{2}{*}[102]{} \\
\hline & & & - & \\
\hline \multirow[t]{2}{*}{ Bacillus coagulans } & & $\begin{array}{c}\mathrm{C}_{\mathrm{i}}=50 \mathrm{mg} / \mathrm{L} ; \mathrm{pH}=5 ; \mathrm{T}=23{ }^{\circ} \mathrm{C} ; \\
\mathrm{D}=1 \mathrm{~g} / \mathrm{L} ; \mathrm{t}=6 \mathrm{~min} ;\end{array}$ & - & \multirow[t]{2}{*}[101]{} \\
\hline & & Agitation speed (rpm): 160 & $17.53 \mathrm{mg} / \mathrm{g}$ & \\
\hline \multirow{2}{*}{ Bacillus xiamenensis } & & \multirow{2}{*}{$\begin{array}{c}\mathrm{C}_{\mathrm{i}}=100-200 \mathrm{mg} / \mathrm{L} ; \mathrm{pH}=6 ; \mathrm{T}=35^{\circ} \mathrm{C} ; \\
\mathrm{D}=1 \mathrm{~g} / \mathrm{L} ; \mathrm{t}=144 \mathrm{~h} ; \\
\text { Agitation speed }(\mathrm{rpm})=140\end{array}$} & $99.19 \%$ & \multirow{2}{*}{ [112] } \\
\hline & & & $216.75 \mathrm{mg} / \mathrm{g}$ & \\
\hline \multirow{2}{*}{ Acinetobacter junii } & & $\mathrm{C}_{\mathrm{i}}=100 \mathrm{mg} / \mathrm{L} ; \mathrm{pH}=2 ; \mathrm{T}=27^{\circ} \mathrm{C} ; \mathrm{D}(\mathrm{g} / \mathrm{L})=2 ;$ & $\begin{array}{c}44.4 \% \\
\text { (logarithmic phase), } \\
27.7 \% \\
\text { (stationary phase) }\end{array}$ & [98] \\
\hline & $\mathrm{Cr}(\mathrm{VI})$ & $\mathrm{t}=120 \mathrm{~min}$ & $\begin{array}{c}22.22 \mathrm{mg} / \mathrm{g} \\
\text { (logarithmic phase), } \\
13.88 \mathrm{mg} / \mathrm{g} \\
\text { (stationary phase) }\end{array}$ & \\
\hline & & & $68.54 \%$ & \\
\hline Stenotrophomonas sp. & & & - & \\
\hline V1 he illamme & & & $65.98 \%$ & \\
\hline Klebsıellapneumonıаe & & Agitation speed $(\mathrm{rpm})=150$ & - & [102] \\
\hline Ctanlulococonon & & & $71.45 \%$ & \\
\hline Staphylococcus sp. & & & - & \\
\hline & & $\mathrm{C}_{\mathrm{i}}=200 \mathrm{mg} / \mathrm{L} ; \mathrm{pH}=7 ; \mathrm{T}=37^{\circ} \mathrm{C}$; & $48.78 \%$ & \\
\hline Stenotrophomonas sp. & $\mathrm{Ni}(\mathrm{II})$ & Agitation speed $(\mathrm{rpm})=150$ & - & [102] \\
\hline
\end{tabular}


Table 1. Cont.

\begin{tabular}{|c|c|c|c|c|}
\hline Microorganism & Metal & Optimal Conditions & $\begin{array}{l}\text { Efficiency/Sorption } \\
\text { Capacity }\end{array}$ & Ref. \\
\hline \multicolumn{5}{|c|}{ FUNGI } \\
\hline \multirow{2}{*}{ Saccharomyces cerevisiae } & \multirow[b]{2}{*}{$\operatorname{Hg}(\mathrm{II})$} & \multirow{2}{*}{$\begin{array}{c}\mathrm{C}_{\mathrm{i}}=79.8 \mu \mathrm{g} / \mathrm{L} ; \mathrm{pH}=5.45 \\
\mathrm{D}=47.7 \times 10^{7} \mathrm{CFU}\end{array}$} & $99.4 \%$ & \multirow[b]{2}{*}[113]{} \\
\hline & & & - & \\
\hline \multirow{2}{*}{ Aspergillus flavus } & \multirow{2}{*}{$\operatorname{Hg}(\mathrm{II})$} & \multirow{2}{*}{$\begin{array}{c}\mathrm{C}_{\mathrm{i}}=10 \mathrm{mg} / \mathrm{L} ; \mathrm{T}=30{ }^{\circ} \mathrm{C} ; \\
\mathrm{pH}=4.13 \text { (shaken system), respectively } 4.01 \text { (static } \\
\text { system); } \mathrm{D}=108 \text { spore } / \mathrm{mL} \text { fungal spore } \\
\text { suspension; } \\
\text { dry mass }=14.9 \mathrm{~g} / \mathrm{L} \text { (shaken system), respectively } \\
14.3 \mathrm{~g} / \mathrm{L} \text { (static system) }\end{array}$} & $\begin{array}{c}97.50 \% \\
\text { (shaken system); } \\
98.73 \% \\
\text { (static system) }\end{array}$ & \multirow{2}{*}[66]{} \\
\hline & & & $\begin{array}{l}6.55 \mathrm{Hg}(\mathrm{mg} / \mathrm{L}) / \mathrm{g} \text { dry } \\
\text { weight } \\
\text { (shaken system); } \\
\text { 6.91 } \mathrm{Hg}(\mathrm{mg} / \mathrm{L}) / \mathrm{g} \text { dry } \\
\text { weight } \\
\text { (static system) }\end{array}$ & \\
\hline \multirow{2}{*}{$\begin{array}{l}\text { Aspergillus } \\
\text { fumigatus and } \\
\text { Aspergillus flavus } \\
\text { (consortium) }\end{array}$} & \multirow[t]{2}{*}{$\mathrm{Cd}(\mathrm{II})$} & \multirow[t]{2}{*}{$\begin{array}{l}\quad \mathrm{C}_{\mathrm{i}}=100 \mathrm{mg} / \mathrm{L} ; \mathrm{pH}=5 ; \\
\mathrm{T}=30^{\circ} \mathrm{C} ; \mathrm{D}=6 \% ; \mathrm{t}=144 \mathrm{~h} \\
\text { Agitation speed }(\mathrm{rpm})=120\end{array}$} & $82.21 \pm 1.00 \%$ & \multirow[t]{2}{*}[114]{} \\
\hline & & & $5.51 \pm 1.23 \mathrm{mg} / \mathrm{g}$ & \\
\hline \multirow[t]{2}{*}{ Trichoderma sp. } & \multirow[t]{2}{*}{$\mathrm{Cu}(\mathrm{II})$} & \multirow{2}{*}{$\begin{array}{c}\text { Temperature }\left({ }^{\circ} \mathrm{C}\right): 27 \pm 3{ }^{\circ} \mathrm{C} ; \\
\mathrm{pH}: 6.5 \text {; Agitation speed: } 200 \text { rev.min } \\
\text { Contact time }(\mathrm{h}): 144\end{array}$} & $80 \%$ & \multirow{2}{*}[115]{} \\
\hline & & & $19.6 \mathrm{mg} / \mathrm{g}$ & \\
\hline \multirow{2}{*}{ Aspergillus niger } & \multirow{4}{*}{$\mathrm{Cr}(\mathrm{III})$} & \multirow{4}{*}{$\begin{array}{c}\mathrm{C}_{\mathrm{i}}=240 \mathrm{mg} / \mathrm{L} ; \mathrm{pH}=5.3, \text { respectively } 5.5 ; \mathrm{T}=30^{\circ} \mathrm{C} ; \\
\mathrm{D}=0.3 \mathrm{~g} / 100 \mathrm{~mL} ; \\
\text { Optimum nutrients dose }=1 \mathrm{~g} / \mathrm{L} \text { urea; } \\
\text { Agitation speed }=150 \mathrm{rpm}\end{array}$} & $72 \%$ & \multirow{2}{*}{ [116] } \\
\hline & & & $185 \mathrm{mg} / \mathrm{g}$ & \\
\hline Aspergillus & & & $67 \%$ & \\
\hline oryzae & & & $208 \mathrm{mg} / \mathrm{g}$ & \\
\hline $\begin{array}{l}\text { Cladosporeum } \\
\text { perangustumm, } \\
\text { Penicillium commune, } \\
\text { Paecilomyces lilacinus, }\end{array}$ & \multirow{3}{*}{$\mathrm{Cr}(\mathrm{VI})$} & \multirow[t]{2}{*}{$\begin{array}{c}\mathrm{pH}=4 ; \mathrm{T}=28^{\circ} \mathrm{C} \\
\mathrm{t}=48 \mathrm{~h}\end{array}$} & $73.73 \%$ & \multirow[t]{2}{*}[117]{} \\
\hline $\begin{array}{c}\text { Fusarium equiseti } \\
\text { (consortium) }\end{array}$ & & & - & \\
\hline $\begin{array}{l}\text { Aspergillus flavus and } \\
\text { Aspergillus } \\
\text { fumigatus } \\
\text { (consortium) } \\
\end{array}$ & & $\begin{array}{c}\mathrm{C}_{\mathrm{i}}=100 \mathrm{mg} / \mathrm{L} ; \mathrm{pH}=5 ; \mathrm{T}=30^{\circ} \mathrm{C} ; \\
\text { Optimum inoculum size }=6 \% \\
\text { Agitation speed }=120 \mathrm{rpm} ; \mathrm{t}=144 \mathrm{~h}\end{array}$ & $\begin{array}{c}81.25 \pm 0.25 \% \\
5.78 \pm 1.17 \mathrm{mg} / \mathrm{g} \\
\end{array}$ & {$[114]$} \\
\hline
\end{tabular}

$\mathrm{C}_{\mathrm{i}}=$ Initial concentration, $\mathrm{t}=$ Contact time, $\mathrm{T}=$ Temperature, $\mathrm{D}=$ Biosorbent dose.

As far as fungi sorbents are concerned, simultaneous removal of $\mathrm{Cr}$, As and $\mathrm{Cd}$ metals by applying the fungal species $P$. chrysosporium produced a removal efficiency of $9.28 \mathrm{mg} / \mathrm{L}, 14.15 \mathrm{mg} / \mathrm{L}$, respectively $4.53 \mathrm{mg} / \mathrm{L}$ at optimal values of $30^{\circ} \mathrm{C}, 120 \mathrm{rpm}$ and the equilibrium time of one hour. At the same time, the results obtained for the individual biosorption of each metal indicated for arsenic a double efficiency, whereas in case of cadmium a four times higher performance was observed [104]. Five fungal strains in viable form (Aspergillus terreus AML02, Paecilomyces fumosoroseus 4099, Beauveria bassiana 4580, Aspergillus terreus PD-17 and Aspergillus fumigatus PD-18, respectively) were used to study the remediation process of multi-metal solution containing $\mathrm{Cd}, \mathrm{Cr}, \mathrm{Cu}, \mathrm{Ni}, \mathrm{Pb}$ and $\mathrm{Zn}$. For an initial concentration of $30 \mathrm{mg} / \mathrm{L}$, the highest accumulation capacity of the metal solution was determined for B. bassiana $(26.94 \pm 0.07 \mathrm{mg} / \mathrm{L})$ and A. fumigatus (27.59 $\pm 0.09 \mathrm{mg} / \mathrm{L})$. Moreover, the use of Aspergillus fumigatus has reduced the concentrations of metals $\mathrm{Cd}, \mathrm{Cu}, \mathrm{Ni}, \mathrm{Pb}$ and $\mathrm{Zn}$ to values that meet the limits imposed by the FAO (Food and Agriculture Organization) for irrigation water. Also, it was noticed in the case of exposure to the multimetallic solution the increase of the duration of the lag phase of development of the fungal species used, from $6-7 \mathrm{~h}$ to $17-18 \mathrm{~h}$ [118]. A comparative study of chromium removal using Penicillium chrysogenum and Aspergillus niger species indicated a higher efficiency of the remediation process for viable forms [81]. Furthermore, 
the removal of $\mathrm{Cd}(\mathrm{II})$ concentrations of $162.71 \pm 1.3 \mathrm{mg} / \mathrm{L}$ and $81.39 \pm 2.58 \mathrm{mg} / \mathrm{L}$ from real effluents was achieved in a proportion of $69.1 \pm 0.19 \%$ and $72.05 \pm 1.40 \%$, respectively, by applying a consortium of fungi comprising Aspergillus flavus and Aspergillus fumigatus in active form [114].

As in the case of other microorganisms, also for fungal species such as Aspergillus niger applied for the removal of $\mathrm{Cu}$ (II) and $\mathrm{Pb}$ (II) ions, two phases of the biosorption process were observed, namely a shorter phase (10-20 min), followed by a phase of gradual increase or decrease of the biosorption efficiency correlated with the transport of the metal through the cell membrane or intracellular diffusion with reduced speed through the cell wall [119]. Table 2 synthesizes some results identified in recent research studies regarding the removal of heavy metals by microbial inactive biomass.

Table 2. Heavy metals removal by microbial inactive biomass.

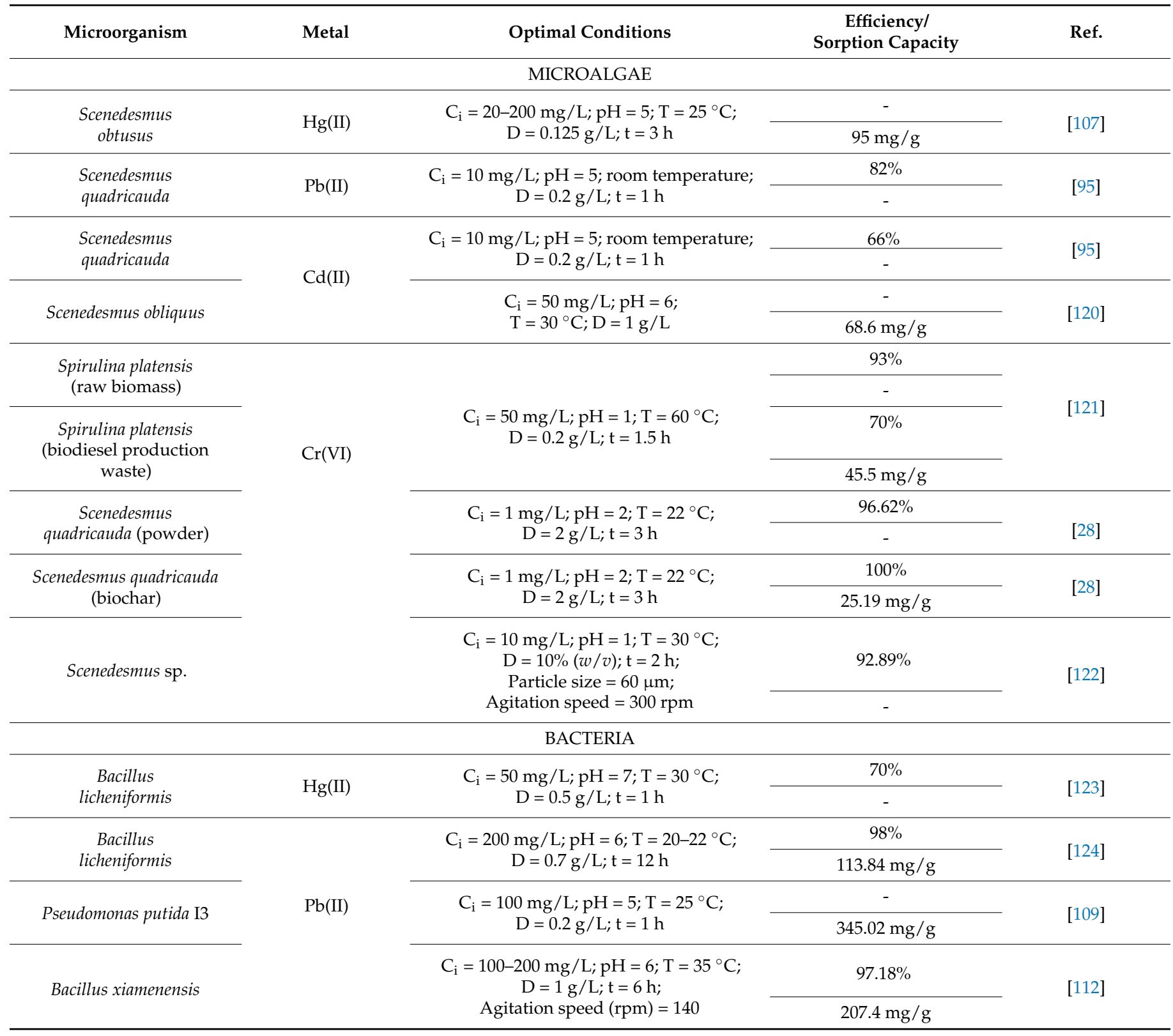


Table 2. Cont.

\begin{tabular}{|c|c|c|c|c|}
\hline Microorganism & Metal & Optimal Conditions & $\begin{array}{l}\text { Efficiency/ } \\
\text { Sorption Capacity }\end{array}$ & Ref. \\
\hline \multirow{2}{*}{$\begin{array}{l}\text { Bacillus } \\
\text { cereus }\end{array}$} & \multirow{6}{*}{$\mathrm{Cd}(\mathrm{II})$} & \multirow{2}{*}{$\mathrm{C}_{\mathrm{i}}=200 \mathrm{mg} / \mathrm{L} ; \mathrm{pH}=6 ; \mathrm{T}=35^{\circ} \mathrm{C} ; \mathrm{t}=20 \mathrm{~h}$} & $82 \%$ & \multirow{2}{*}[125]{} \\
\hline & & & - & \\
\hline \multirow{2}{*}{ Bacillus megaterium } & & \multirow{2}{*}{$\begin{array}{c}\mathrm{C}_{\mathrm{i}}=100 \mathrm{mg} / \mathrm{L} ; \mathrm{pH}=4 ; \mathrm{T}=30^{\circ} \mathrm{C} \\
\mathrm{D}=3 \mathrm{~g} / \mathrm{L} ; \mathrm{t}=2 \mathrm{~h}\end{array}$} & $90 \%$ & \multirow{2}{*}{ [126] } \\
\hline & & & $15.1 \mathrm{mg} / \mathrm{g}$ & \\
\hline \multirow{2}{*}{ Brevundimonas sp. ZF12 } & & \multirow{2}{*}{$\mathrm{C}_{\mathrm{i}}=50 \mathrm{ppm} ; \mathrm{pH}=6 ; \mathrm{T}=30^{\circ} \mathrm{C} ; \mathrm{t}=1 \mathrm{~h}$} & $60 \%$ & \multirow{2}{*}[76]{} \\
\hline & & & $49.01 \mathrm{mg} / \mathrm{g}$ & \\
\hline \multirow{2}{*}{$\begin{array}{l}\text { Sulphate reducing } \\
\text { bacteria }\end{array}$} & \multirow[t]{2}{*}{$\mathrm{Cd}(\mathrm{II})$} & \multirow{2}{*}{$\begin{array}{c}\mathrm{pH}=8 ; \mathrm{T}=35^{\circ} \mathrm{C} ; \mathrm{t}=24 \mathrm{~h} \\
0.015 \mathrm{~g} \mathrm{SRB} \text { (dry weight) } / \mathrm{g} \text { beads (dry } \\
\text { weight) }\end{array}$} & - & \multirow[t]{2}{*}[127]{} \\
\hline & & & $160 \mathrm{mg} / \mathrm{g}$ & \\
\hline \multirow{2}{*}{ Bacillus laterosporus } & \multirow{2}{*}{$\mathrm{Ni}(\mathrm{II})$} & \multirow{2}{*}{$\begin{array}{c}\mathrm{C}_{\mathrm{i}}=10-20 \mathrm{mg} / \mathrm{L} ; \mathrm{pH}=7 ; \mathrm{T}=30{ }^{\circ} \mathrm{C} ; \\
\mathrm{D}=40 \mathrm{~g} / \mathrm{L} ; \mathrm{t}=2 \mathrm{~h}\end{array}$} & - & \multirow{2}{*}[128]{} \\
\hline & & & $44.44 \mathrm{mg} / \mathrm{g}$ & \\
\hline \multirow{2}{*}{ Acinetobacter junii } & \multirow{2}{*}{$\mathrm{Cr}(\mathrm{VI})$} & \multirow{2}{*}{$\begin{array}{c}\mathrm{C}_{\mathrm{i}}=100 \mathrm{mg} / \mathrm{L} ; \mathrm{pH}=2 ; \mathrm{T}=27{ }^{\circ} \mathrm{C} ; \\
\mathrm{D}=2 \mathrm{~g} / \mathrm{L} ; \mathrm{t}=120 \mathrm{~min}\end{array}$} & - & \multirow{2}{*}[98]{} \\
\hline & & & $6.94 \mathrm{mg} / \mathrm{g}$ & \\
\hline \multicolumn{5}{|c|}{ FUNGI } \\
\hline \multirow{4}{*}{ Aspergillus niger } & \multirow{6}{*}{$\mathrm{Pb}(\mathrm{II})$} & \multirow{2}{*}{$\begin{array}{c}\mathrm{C}_{\mathrm{i}}=200-1400 \text { ppm; } \mathrm{pH}=4-5.4 ; \\
\mathrm{T}=37^{\circ} \mathrm{C}\end{array}$} & - & \multirow{2}{*}[119]{} \\
\hline & & & 3.25 to $172.25 \mathrm{mg} / \mathrm{g}$ & \\
\hline & & \multirow{2}{*}{$\begin{array}{l}\mathrm{C}_{\mathrm{i}}=10,50,100 \mathrm{mg} / \mathrm{L} ; \mathrm{pH}=5 \\
\mathrm{~T}=30^{\circ} \mathrm{C} ; \mathrm{D}=70 \mathrm{~g} / \mathrm{L} ; \mathrm{t}=1.5 \mathrm{~h}\end{array}$} & - & \multirow[b]{2}{*}[129]{} \\
\hline & & & $\begin{array}{c}137.3 \mathrm{mg} / \mathrm{g} ; 398.3 \mathrm{mg} / \mathrm{g} \\
564 \mathrm{mg} / \mathrm{g}\end{array}$ & \\
\hline \multirow{2}{*}{$\begin{array}{l}\text { Fusarium sp. } \\
\text { (two strains) }\end{array}$} & & \multirow{2}{*}{$\begin{array}{l}\mathrm{C}_{\mathrm{i}}=90 \mathrm{mg} / \mathrm{L} ; \mathrm{pH}=6 ; \mathrm{T}=49,85^{\circ} \mathrm{C} ; \mathrm{D}=1 \\
\mathrm{~g} / \mathrm{L} ; \mathrm{t}=1 \mathrm{~h} ; \text { Agitation speed }(\mathrm{rpm})=150\end{array}$} & - & \multirow{2}{*}[130]{} \\
\hline & & & $\begin{array}{c}232.56 \text { (ZSY strain), } \\
263.16 \mathrm{mg} / \mathrm{g} \text { (MJY strain) }\end{array}$ & \\
\hline \multirow{2}{*}{ Saccharomyces cerevisiae } & \multirow{2}{*}{$\mathrm{Cd}(\mathrm{II})$} & $\mathrm{C}_{\mathrm{i}}=50 \mathrm{mg} / \mathrm{L} ; \mathrm{pH}=6 ; \mathrm{T}=40^{\circ} \mathrm{C} ; \mathrm{D}=5 \mathrm{~g} / \mathrm{L} ;$ & - & \\
\hline & & Agitation speed (rpm): 150 & $7.252 \mathrm{mg} / \mathrm{g}$ & [131] \\
\hline Trichoderma sp & $\mathrm{Cu}(\mathrm{II})$ & $\mathrm{T}=27 \pm 3{ }^{\circ} \mathrm{C} ; \mathrm{D}=3 \mathrm{~g} / \mathrm{L} ; \mathrm{t}=4 \mathrm{~h}$ & - & [115] \\
\hline 1richouermu sp. & & Agitation speed $=200$ rev.min ${ }^{-1}$ & $23.01 \mathrm{mg} / \mathrm{g}$ & {$[110]$} \\
\hline Penicillium & $\mathrm{Cr}(\mathrm{VI})$ & $\mathrm{C}_{\mathrm{i}}=67.8 \mathrm{mg} / \mathrm{L} ; \mathrm{pH}=2 ; \mathrm{T}=27^{\circ} \mathrm{C}$; & $79.9 \%$ & [132] \\
\hline griseofulvum & & $\mathrm{D}=2 \mathrm{~g} / \mathrm{L} ; \mathrm{t}=37.5 \mathrm{~min}$ & $75.1 \mathrm{mg} / \mathrm{g}$ & {$[132]$} \\
\hline
\end{tabular}

$\mathrm{C}_{\mathrm{i}}=$ Initial concentration, $\mathrm{t}=$ Contact time, $\mathrm{T}=$ Temperature, $\mathrm{D}=$ Biosorbent dose.

\section{Bioremediation of Persistent Organic Pollutants Contaminated Wastewaters by Microorganisms}

\subsection{Mechanisms of Persistent Organic Pollutants Removal by Microorganisms}

The POPs released in environment either are accumulated and biomagnified along the food chain or are transformed under the action of biotic and abiotic factors into modified, less complex and less toxic organic compounds [2,133-135].

Understanding the metabolic pathways involved in microbial degradation of persistent organic pollutants will expand our ability to enhance the remediation process of wastewaters. Due to the POPs structural complexity, the free cells of tolerating microorganisms are able to remove the pollutants from aqueous solutions by one or more mechanisms [35,134,136-138] (Figure 7) described as:

- biosorption (I),

- bioaccumulation (II),

- cometabolism (III),

- biotransformation (IV)

- biomineralization (V) and

- $\quad$ extracellular biodegradation (VI). 
Biosorption is the mechanism independent of metabolic activities of microbial cell [53] which is based on the interaction of persistent organic pollutant molecules with functional groups found in the cell wall constituents (e.g., carboxyl, phosphoryl, amine etc.) [24,35,139] and/or on the retention of persistent organic pollutants molecules on the biosorbent surface due to hydrophobic interaction and van der Waals forces [139]. In the biosorption process, the microbial biomass used is frequently inactivated by thermal processes, but some researchers also use freeze-dried biomass [139]. The interactions realized between microbial biomass and POPs depend on the chemical structure and proprieties of a particular POPs, as well as the specific chemistry of the microbial biomass [24,139]. According to Aksu [139] "the size of cells, morphology and chemical composition as well as the number of the active adsorption sites and POPs distribution and molecular size and reactivity as well as their mobility in the solution phase" can significantly affect the pollutant retention performance. For the majority of microbial biosorbents, the cell surface is negatively charged due to the higher proportion of carboxyl, phosphoryl, amine and other functional groups in the cell wall compounds and pollutants with cationic groups are actively attracted through electrostatic interaction [24]. Escherichia coli, Zooglea ramigera, Bacillus megaterium, Bacillus subtilis, Zoogloea ramigera, Rhizopus oryzae, Mucor racemosus, Rhizopus arrhizus, Sporothrix cyanescens, Emericella nidulans, Bacillus pumilus are some of microbial strains studied for lindane, pentachloronitrobenzene, 2,4-dichlorophenoyacetic acid, 1,2,3,4-tetrachlorodibenzo- $p$-dioxin, or polychlorinated dibenzofurans biosorption [139-144].

The study conducted by Bell and Tsezos [141] asserts that lindane, pentachlorophenol and 2-chlorobiphenyl are removed by Rhizopus arrhizus inactivated biomass by physical mechanisms (adsorption). According to the Ju et al. [140] study, hydrophobic interaction and van der Waals forces are involved in the biosorption of lindane by Escherichia coli, Zooglea ramigera, Bacillus megaterium, Bacillus subtilis. In another study, the lindane is removed by heat treated Rhizopus oryzae by "physical bonding of the negatively charged lindane molecule to the negatively charged fungal cell wall with hydrogen ions acting as the bridging ligand" [142]. The dead and live biomass of Bacillus pumilus was used for removal of 1,2,3,4-tetrachlorodibenzo- $p$-dioxin and some polychlorinated dibenzofurans. The study conducted by Hong et al. [143] proved that dead biomass of Bacillus pumilus remove more effectively the POPs studied than live cells.

Bioaccumulation is the mechanism by which POPs after their penetration inside the cells of microbial species, bioconcentrate without changing their structure [145]. In general, the POPs that penetrate inside cells undergo some transformations that result in insoluble metabolites that are subsequently bioaccumulated [146-152]. The analysis of the published studies shows that the most part of the studied microorganisms have the ability to metabolize POPs and not to bioaccumulate them inside their cells. Azospirillum lipoferum is one of the microbial strains able to remove dicofol by bioaccumulation and thus enhance the persistence of this pollutant in soil [153].

Biodegradation of POPs based enzymes is one of the most important mechanism involved in microbial bioremediation of liquid environment contaminated with POPs. Various classes of transferase, isomerase, hydrolase and other enzymes catalyze the hydrolysis, oxidation/reduction, addition of oxygen to a double bond, oxidation of amino group $\left(-\mathrm{NH}_{2}\right)$ to a nitro group, hydroxyl group addition to a benzene ring, dehalogenation, reduction of a nitro group $\left(\mathrm{NO}_{2}\right)$, sulphur replacement with oxygen, metabolism of side chains, ring cleavage, etc. The biodegradation of POPs mediated by enzymes can take place either inside or outside the microbial cells. The intra- or extracellular biodegradation by enzymes depends significantly on the solubility of xenobiotics compounds. Gianfreda et al. [154] ascertain that the soluble POPs can easily enter in cells and thus interact with intracellular enzymatic systems, but the insoluble substances cannot enter cells being firstly extracellular transformed into soluble or easily cell available products. 


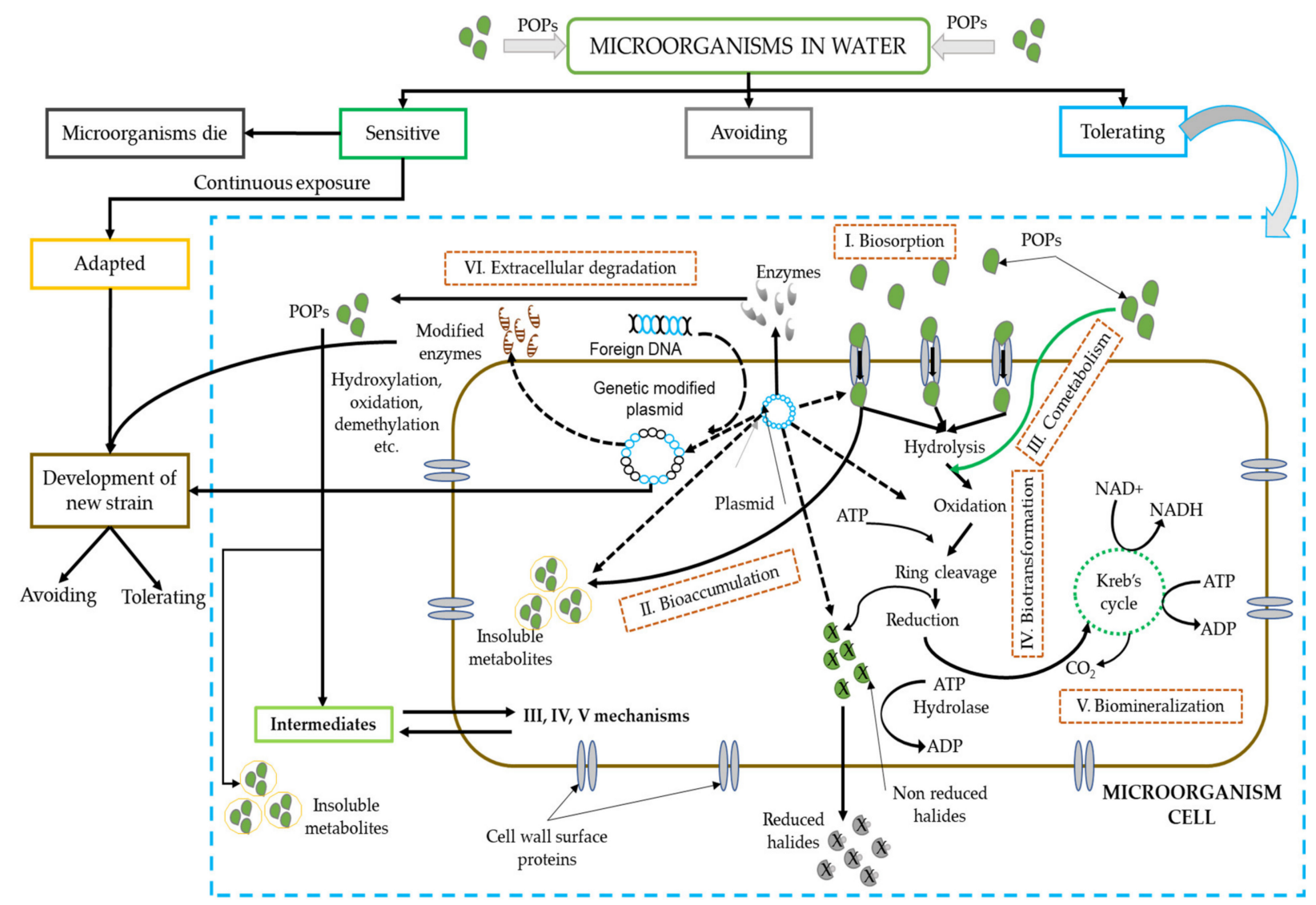

Figure 7. POPs removal strategy followed by microorganisms: the bioremediation mechanisms followed during the interaction between microorganism cell and POPs.

Extracellular biodegradation of POPs occurs as a result of the interaction between pollutant and extracellular enzymes and glycoconjugates released by cells $[155,156]$. Oxidoreductases, oxygenases, monooxygenases, dioxygenases, laccases, peroxidases are the main extracellular enzymes released by microorganisms, involved in the detoxification of toxic organic compounds $[157,158]$. Since there are POPs with very low solubility in water and high molecular mass for their extracellular biodegradation, the microorganisms release hydrolytic enzymes which disrupt major chemical bonds [157]. Examples of such enzymes are: lipases, cellulases, proteases, hemicellulose etc. $[157,158]$. The extracellular glycoconjugates involved in POPs removal are rhamnolipids, sophorolipids, exopolysaccharides, glycoproteins and glycol-lipopeptides [156] which are deliberately released by the cells as a result of normal metabolic activity or as a result of the cell defense system activation against pollutant toxicity $[156,159]$. The glycoconjugates produced by microbial strains facilitate the uptake of the POPs, enhance the biodegradation of hydrophobic pollutants, reduce the surface and interfacial tension etc. [156].

The results of the majority of studies focused on the identification of intracellular enzymes showed the involvement of cytochrome P450 family (CYP) epoxidases and transferases enzymes in intracellular biodegradation of persistent organic pollutants [160]. The cytochrome P450 enzymes have been shown to be the catalysts of hydroxylation, heteroatom oxygenation, dealkylation, epoxidation of $C=C$ bonds, reduction and dehalogenation reactions [160]. Cytochrome $\mathrm{P} 450$ have been identified as responsible for biodegradation of hexabromocyclododecane and 1,1,1-trichloro-2,2-bis(4-chlorophenyl) ethane by Rhodopseudomonas palustris [147], respectively Trichoderma hamatum FBL 587 [161]. The main types of enzymes involved in the biodegradation of POPs as well as the genes which encoding the enzymes are presented in Table 3. 
Dalton and Stirling [162] defined the cometabolism of organic substances as "the transformation of non-growth-substrate in the obligate presence of a growth-substrate or another transformable compound". The cometabolism reactions involved in organic pollutant biodegradation are catalyzed by oxygenase enzymes secreted by microorganisms [163]. Examples of such enzymes are: methane-mono-oxygenase (MMO), mono- and dioxygenase, ammonia mono-oxygenase and biphenyl oxygenase [163]. According to Alvarez et al. [164] "even the most persistent organic pollutant can be metabolized to some extent by microbial cultures, either by utilization of the compounds as a source of energy or nutrients, or by cometabolism with other substrates supporting microbial growth". Microorganisms such as of Bacillus cereus HWB1, Pseudomonas taiwanensis ECAe22, Fusarium verticillioides AT-100, Pseudoxanthomonas sp., Janibacter sp. have biodegraded 4-chlorophenol, 4-nitrophenol, lindane, 1,1,1-trichloro2,2-bis( $p$-chlorophenyl)ethane (DDT) and pentaclorophenol with high efficiencies only in the presence of carbon sources such as yeast extract, $A$. tequilana leaves, glucose, succinate, starch, dextrin and maltose [148-150,165-167]. These results actually show that the biodegradation of persistent organic pollutants by microbial strains was mainly achieved through a cometabolic mechanism.

A variety of microbial strains have the capacity to degrade the POPs by reduction, oxidation, hydrolysis, dehalogenation, and methylation reactions catalyzed by enzymes. These reactions lead to a complete or partial mineralization of POPs and which result in a wide variety of metabolites, $\mathrm{CO}_{2}$ and energy. The metabolic pathways involved in biotransformation of POPs depend on the type of pollutant as well as microbial strain. Rhodotorula sp. VITJzN0 was able to transform the lindane in $\gamma$-pentachlorocyclohexane, 1,3,4,6-tetrachloro-1,4-cyclohexadiene, 1,2,4-trichlorobenzene, 1,4-dichlorobenzene, chlorocis-1,2-dihydroxycyclohexadiene, 3-chlorocatechol, maleylacetate following dechlorination, dehydrochlorination, oxidation reactions [168]. Stenotrophomonas maltophilia OG2 by hydrolysis transformed endosulfan in endosulfan diol, endosulfan ether and endosulfan lactone [151].

Table 3. The POPs metabolizing enzymes of microbial strains.

\begin{tabular}{|c|c|c|}
\hline POPs & Genes Encoding Enzymes & POPs-Metabolizing Enzymes \\
\hline Polychlorinated dibenzo-p-dioxins & $d x n A 1, d x n A 2, f d x 1$ and $\operatorname{red} A 2$ [169] & $\begin{array}{c}\text { Dioxygenase, cytochrome P450, lignin peroxidase, } \\
\text { dehalogenase [170], 2-haloacid dehalogenase [171], } \\
\text { carbazole 1,9a-dioxygenase, aromatic ring hydroxylating } \\
\text { dioxygenase [169] }\end{array}$ \\
\hline Lindane & Lin genes $[172,173]$ & $\begin{array}{l}\text { Permease, ATPase, periplasmic protein and lipoprotein } \\
\text { [172], dehydrochlorinase, halidohydrolase, dehydrogenase, } \\
\text { dechlorinase, ring-cleavage dioxygenase, maleylacetate } \\
\text { reductase, phosphoesterases and catechol 1,2-dioxygenase } \\
\text { [173], lindane dechlorinase, lindane dehalogenase, DCHQ } \\
\text { reductive dechlorinase, Mn peroxidase and lignin } \\
\text { peroxidase [174] }\end{array}$ \\
\hline Endosulfan & Ese gene [175] & Esd monooxygenase [175] \\
\hline Pentachlorophenol & $p c p A, p c p B, p c p C, p c p D$ and $p c p E[176,177]$ & $\begin{array}{l}\text { PCP hydroxylase (PcpB) and PcpD (TCBQ reductase), } \\
\text { TCHQ dehalogenase, 2,6-dichloro-hydroquinone } \\
\text { dioxygenase, maleylacetate reductase }[176,177]\end{array}$ \\
\hline Hexabromocyclododecane & $\begin{array}{c}\text { LysR, GST, Cyt C, p450, HADH, RegA, CcoN, CcoO, } \\
\text { CcoP and CcoQ [147] }\end{array}$ & $\begin{array}{l}\text { Haloalkane dehalogenases linA2 and linB [178], } \\
\text { fluoroacetate dehalogenase, protocatechuate } \\
\text { 4,5-dioxygenase, dioxygenase, peroxidase, } \\
\text { P450 monooxygenase and dehalogenase [147] }\end{array}$ \\
\hline Decabromodiphenyl ether (BDE 209) & $\begin{array}{c}\text { Alcohol dehydrogenase genes, COG0625 (Glutathione } \\
\text { S-transferase gene), COG2124 (Cytochrome P450 } \\
\text { enzymes gene), COG0778 (nitroreductase gene) } \\
\text { COG3805 (aromatic ring-cleaving dioxygenase gene) } \\
\text { and COG0596 (predicted hydrolases or } \\
\text { acyltransferases (alpha/beta hydrolase superfamily } \\
\text { gene)) [179] }\end{array}$ & $\begin{array}{c}\text { Biphenyl 2,3-dioxygenase, catechol 2,3- dioxygenase, } \\
\text { cytochrome P450/NADPH-cytochrome P450 reductase, } \\
\text { glutathione S-transferase and } \\
\text { nitroreductase/dihydropteridine reductase [179] }\end{array}$ \\
\hline $\begin{array}{l}\text { 1,1,1-Trichloro-2,2-bis(4-chlorophenyl) ethane } \\
\text { (DDT) }\end{array}$ & $\begin{array}{l}\text { ProtID g128, ProtID g8100, ProtID g3303, ProtID } \\
\text { g1796 and g8655, ProtID g8027, ProtID g5890, } \\
\text { ProtID g1645, ProtID g3541 [161] }\end{array}$ & $\begin{array}{l}\text { Dioxygenase and lignin peroxidase [180], epoxide } \\
\text { hydrolases, FAD-dependent monooxygenases, glycosyl- } \\
\text { and glutathione-transferases, cytochrome P450 } \\
\text { monooxygenase sdnT, cytochrome P450 monooxygenase, } \\
\text { superoxide dismutase, DyP-type peroxidase, putative } \\
\text { secreted hydrolase [161] }\end{array}$ \\
\hline
\end{tabular}




\subsection{Factors Affecting Microbial Remediation of POPs in Wastewaters}

The normal metabolic activity of microbial strains during the bioremediation of POPs could be affected by a diversity of factors, which can be grouped as [136,181]:

- Abiotic factors (environmental conditions such as: ambient temperature, $\mathrm{pH}$ of liquid medium, available nutrients, contact time between pollutant and microbial strain, inoculum size [145,168,182,183], the presence of oxygen etc. [183].

- Biotic factors (e.g., plasmid-encoded genes, bacterial chemotaxis, complex multispecies interactive networks etc.) [136],

- Factors related to the pollutant proprieties: chemical nature, toxicity, initial concentration of POPs in liquid medium, availability, solubility etc. [181].

According to the data of many researchers, biodegradation of POPs can occur in a wide $\mathrm{pH}$ range, but for the main microorganisms it was observed that the optimum $\mathrm{pH}$ value is $7[148,166,174,184-190]$. Since the biodegradation of POPs is dependent on the cellular metabolism, the best performances for POPs biodegradation were obtained mostly at the optimum $\mathrm{pH}$ for microbial strain growth. For example, at $\mathrm{pH}$ value of 7 the microorganisms Kocuria sp. DAB-1Y, Staphylococcus sp. DAB-1W, Sphingobium japonicum have the highest performance both for growth and for biodegradation of lindane (efficiencies up to 94\%) [185]. Also, Bacillus cereus HWB1 and Pseudomonas taiwanensis ECAe22 have the same optimal $\mathrm{pH}$ value for both cell growth and 4-Chlorophenol and 4-Nitrophenol biodegradation [166]. Decabromodiphenyl ether (BDE 209) was biotransformed with efficiencies of $55.16 \%$ and $56 \%$ by Stenotrophomonas sp. strain WZN-1 [149], respectively by Pseudomonas aeruginosa [150] at initial $\mathrm{pH}$ of 5, respectively 7.5. Lu et al. [191] highlighted that at $\mathrm{pH}$ above 6 , the dicofol compound was biodegraded by Microbacterium sp. D-2 with a rate above than $70 \%$, the maximum of $81.9 \%$ being reached at $\mathrm{pH} 7$. So, based on published researches, the biodegradation of POPs by microorganisms is most favorable under a neutral range of $\mathrm{pH}$ (between 6 and 8) [165,167,192-194].

In case of temperature, the optimal value at which the best results of POPs biodegradation by microbial strains are obtained is in the range of $25-37^{\circ} \mathrm{C}[149,184,190,195-197]$, but most often, the suitable value of temperature is $30^{\circ} \mathrm{C}[146,148,150,165-168,174,185-$ 189,191,193,198-201]. Due to the fact that microbial metabolism significantly depends on temperature, Bajaj and Singh [37] ascertain that at temperatures below $20^{\circ} \mathrm{C}$, most microorganisms extremely reduce their activity in mesophilic enzymes, causing thus high activation energy, low kinetic energy and slower conformational movements. Also, under cold conditions the viscosity of POPs increases, their volatilization decreases and their bioavailability is reduced [37]. However, there are species of microorganisms that are able to biodegrade persistent organic pollutants even at temperatures below $20^{\circ} \mathrm{C}$. Such examples are Rhodococcus erythropolis $\mathrm{P} 25$ which degraded $26 \%$ of phenanthrene at $15{ }^{\circ} \mathrm{C}$, in 20 days and $17.1 \%$ and $16.0 \%$ at $5{ }^{\circ} \mathrm{C}$, respectively $25^{\circ} \mathrm{C}$ [202]. Another psychrophilic strain is R. erythropolis S-7 which completely degraded 3-chlorobenzoate at 10,20 and $30^{\circ} \mathrm{C}$. However, the faster biodegradation rate occurred at $20^{\circ} \mathrm{C}$ [194]. Sphingobium indicum B90A degraded $48.8 \%$ of $25 \mathrm{mg} / \mathrm{L}$ of lindane at $4{ }^{\circ} \mathrm{C}$ and $97.2 \%$ at $30{ }^{\circ} \mathrm{C}$ [203]. Pseudoalteromonas, Psychrobacter and Arthrobacter genera isolated from Antarctic seawater sample were able to remove polychlorinated biphenyls with efficiencies between $35.6 \%$ and $79.8 \%$ at $4{ }^{\circ} \mathrm{C}$ and between $0.4 \%$ and $82.8 \%$ at $15{ }^{\circ} \mathrm{C}$ [204].

The concentration level of the target pollutant in liquid medium can significantly affect the biomass production as well as the POPs degradation rates [168,174,192]. In their paper, Kumar and Pannu [192] ascertain that a low pollutant concentration in liquid medium sometimes is not enough to activate the secretion of enzymes directly involved in the degradative reactions, while high levels may be toxic to the microorganisms [205]. The strain Candida VITJzN04 has the ability to tolerate lindane, finding that up to $600 \mathrm{mg}$ lindane/L this species degraded completely the pollutant, turning it into a source of energy and thus facilitating biomass production. At $100 \mathrm{mg}$ lindane/L, the biomass production was about $1.3 \mathrm{~g} / \mathrm{L}$ and at $600 \mathrm{mg}$ lindane/L was more than $2.9 \mathrm{~g} / \mathrm{L}$ [174]. The level of pollutant at which microorganisms tolerate a specific POP depends both on the type of pollutant 
and the microorganism specie. For example, Kocuria sp. DAB-IY and Staphylococcus sp. DAB- $1 \mathrm{~W}$ are able to tolerate lindane up to an initial concentration of $100 \mathrm{mg} / \mathrm{L}$ [185], Rhodotorula sp.VITJzN03 up to $600 \mathrm{mg} / \mathrm{L}$ [168] and Microbacterium sp. P27 no more than $50 \mathrm{mg}$ lindane/L [187]. Pentachlorophenol was biodegraded with efficiencies above $99 \%$ by Janibacter sp. [167] and Pseudomonas fluorescens [199] for initial concentration up to $500 \mathrm{mg} / \mathrm{L}$, respectively $200 \mathrm{mg} / \mathrm{L}$ and Cunninghamella sp. UMAS SD12 at $20 \mathrm{mg}$ PCP/L had a maximum degradation efficiency of only $51.7 \%$ [197]. Variation of 1,1,1-trichloro-2,2bis(4-chlorophenyl) ethane (DDT) concentration between 10 and $50 \mathrm{mg} / \mathrm{L}$ does not inhibit the biomass production of Serratia marcescens NCIM 2919, but its biodegradation capacity is up to $42 \%$ [206].

The kinetic studies have shown that the biodegradation rate of POPs is closely correlated with microorganism strain $[184,186-188,191]$, the pollutant proprieties, but also with their concentration in the liquid media [191,205,207]. At concentrations up to $50 \mathrm{mg}$ pentachlorophenol/L, Janibacter sp. was able to remove almost the entire quantity of PCP after $72 \mathrm{~h}$ of incubation time, but at concentrations higher than $200 \mathrm{mg} / \mathrm{L}$ a longer contact time is required for a complete removal of the pollutant [167]. After 8 days of contact time the strains Kocuria sp. DAB-1Y, Staphylococcus sp. DAB-1W and Sphingobium japonicum removed $94-98 \%$ of lindane amount corresponding to the initial concentration of $10 \mathrm{mg} / \mathrm{L}$ [185]. Paracoccus sp. NITDBR1 after the same contact time was able to remove $90.6 \%$ of $100 \mathrm{mg}$ lindane/L [188]. For a complete removal of $600 \mathrm{mg}$ lindane/L, the strain Candida sp. VITJzN04 [174] required a minimum contact time of 6 days, while Rhodotorula sp. VITJzN03, 10 days [168].

Another factor that may have significantly positive or negative effects on biodegradation is the availability of nutrients in liquid medium. Dey et al. [166] showed in their study that the biodegradation capacities for 4-chlorophenol and 4-nitrophenol of Bacillus cereus HWB1 and Pseudomonas taiwanensis ECAe22 were enhanced by increasing the yeast extract concentration in liquid medium from 0.1 to $0.3 \%$. In another study, the biodegradation of lindane by Fusarium verticillioides AT-100 strain was improved by addition of $12 \mathrm{~g} / \mathrm{L}$ A. tequilana leaves in a medium consisting of $\left(\mathrm{NH}_{4}\right)_{2} \mathrm{SO}_{4}, \mathrm{Na}_{2} \mathrm{HPO}_{4}, \mathrm{KH}_{2} \mathrm{PO}_{4}$, Tween 20, $\mathrm{Cu}_{\mathrm{S}} \mathrm{O}_{4} \cdot 5 \mathrm{H}_{2} \mathrm{O}$ and elemental iron [148]. The importance that glucose exerts on the biodegradation performance of POPs by microorganisms was highlighted by the studies conducted by Wang et al. [165] and Khessairi et al. [167]. The addition of $100 \mathrm{mg}$ in $1 \mathrm{~L}$ of minimal salt medium improved the Pseudoxanthomonas sp. biodegradation capability for 1,1,1-trichloro-2,2-bis(p-chlorophenyl)ethane (DDT) from 10.2\% to 95\% [165]. Janibacter sp. in minimal salt medium supplemented with $1 \%$ glucose degraded more than $90 \%$ of $20 \mathrm{mg}$ pentaclorophenol/L in $72 \mathrm{~h} \mathrm{[167].} \mathrm{Wang} \mathrm{et} \mathrm{al.} \mathrm{[165]} \mathrm{specified} \mathrm{that} \mathrm{the} \mathrm{succinate,}$ starch, dextrin and maltose, could also promote the biodegradation of DDT. The results of these studies indicate that the cometabolism is the main mechanism involved in microbial degradation of the mentioned POPs.

\subsection{Persistent Organic Pollutants Removal Performance}

Both viable and inactivated biomass of some species of bacteria and fungi were studied for the removal of POPs from liquid media considering the influence of various factors such as $\mathrm{pH}$, initial pollutant concentration, contact time, agitation speed for flask mixing and temperature. Studies focusing on the removal of POPs by inactivated biomass from microorganisms are few and have been conducted until 2005. In recent years, the majority of researchers have been focused on studying the ability of viable biomass to remove POPs and microbial strains such as Bacillus sp., Pseudomonas sp., Stenotrophomonas sp., Candida sp., Rhodotorula sp. etc. which have shown to have the potential to biodegrade some types of POPs. Thus, in Table 4 are presented the results of some studies whose purpose was to study the biodegradation of POPs by viable biomass, while in Table 5 the performances of inactive microbial biomass in POPs removal are shown. 
Table 4. Persistent organic pollutant removal by living microorganisms.

\begin{tabular}{|c|c|c|c|c|}
\hline Microorganism & POPs & Optimal Conditions & $\begin{array}{l}\text { Efficiency/ } \\
\text { Sorption } \\
\text { Capacity }\end{array}$ & Ref. \\
\hline \multicolumn{5}{|c|}{ BACTERIA } \\
\hline \multirow{2}{*}{ Bacillus subtilis MF447840.1 } & \multirow{2}{*}{ 4-chlorophenol } & \multirow{2}{*}{$\begin{array}{c}\mathrm{pH}=7.4, \mathrm{Ci}=1000 \mathrm{mg} / \mathrm{L} \\
\mathrm{t}=40 \mathrm{~h}, \mathrm{~T}=37^{\circ} \mathrm{C}, \text { agitation speed }=150 \mathrm{rpm}\end{array}$} & $100 \%$ & \multirow{2}{*}{ [196] } \\
\hline & & & - & \\
\hline \multirow{2}{*}{ Azospirillium barasilense } & \multirow{14}{*}{ Dicofol } & \multirow{14}{*}{$\begin{array}{c}\mathrm{pH}=7, \mathrm{Ci}=100 \mathrm{mg} / \mathrm{L} \\
\mathrm{t}=28 \text { days, } \mathrm{T}=27 \pm 1^{\circ} \mathrm{C}\end{array}$} & $75 \%$ & \multirow{14}{*}{ [184] } \\
\hline & & & - & \\
\hline \multirow{2}{*}{ Azotobacter chroococcum } & & & $94 \%$ & \\
\hline & & & - & \\
\hline \multirow{2}{*}{ Klebsilense pneumoneae } & & & $88 \%$ & \\
\hline & & & - & \\
\hline \multirow{2}{*}{ Pseudomonas cepacia } & & & $87 \%$ & \\
\hline & & & - & \\
\hline \multirow{2}{*}{ Bacillus subtilis } & & & $85 \%$ & \\
\hline & & & - & \\
\hline \multirow{2}{*}{ Pseudomonas fluorescens } & & & $82 \%$ & \\
\hline & & & - & \\
\hline \multirow{2}{*}{ Bacillus polymyxa } & & & $84 \%$ & \\
\hline & & & - & \\
\hline \multirow{2}{*}{ Microbacterium sp. D-2 } & \multirow{2}{*}{ Dicofol } & \multirow{2}{*}{$\begin{array}{c}\mathrm{pH}=7, \mathrm{Ci}=50 \mathrm{mg} / \mathrm{L}, \mathrm{t}=24 \mathrm{~h}, \\
\mathrm{~T}=30^{\circ} \mathrm{C}, \text { agitation speed }=180 \mathrm{rpm}\end{array}$} & $85.1 \%$ & \multirow{2}{*}{ [191] } \\
\hline & & & - & \\
\hline Kocuria sp. DAB-1Y & \multirow{3}{*}{ Lindane } & \multirow{3}{*}{$\begin{array}{c}\mathrm{pH}=7, \mathrm{Ci}=10 \mathrm{mg} / \mathrm{L}, \mathrm{t}=8 \text { days, } \\
\mathrm{T}=30^{\circ} \mathrm{C}, \text { agitation speed }=120 \mathrm{rpm}\end{array}$} & $94 \%$ & \multirow{3}{*}{ [185] } \\
\hline Staphylococcus sp. DAB-1W & & & $98 \%$ & \\
\hline Sphingobium japonicum & & & $98 \%$ & \\
\hline \multirow[t]{2}{*}{ Achromobacter sp. A3 } & \multirow[t]{2}{*}{ Lindane } & $\begin{array}{l}\mathrm{pH}=7, \mathrm{Ci}=50 \mathrm{mg} / \mathrm{L} \\
\mathrm{t}=15 \text { days }, \mathrm{T}=30^{\circ} \mathrm{C}\end{array}$ & $88.7 \pm 1.24 \%$ & [186] \\
\hline & & agitation speed = $150 \mathrm{rpm}$ & - & \\
\hline Microbacterium sp. P27 & Lindane & $\begin{array}{l}\mathrm{pH}=7, \mathrm{Ci}=50 \mathrm{mg} / \mathrm{L} \\
\mathrm{t}=15 \text { days }, \mathrm{T}=30^{\circ} \mathrm{C}\end{array}$ & $82.7 \pm 1.79 \%$ & [187] \\
\hline & & agitation speed $=150 \mathrm{rpm}$ & - & \\
\hline Paracoccus sp. NITDBR1 & Lindane & $\begin{array}{c}\mathrm{pH}=7, \mathrm{Ci}=100 \mathrm{mg} / \mathrm{L} \\
\mathrm{t}=8 \text { days, } \mathrm{T}=30^{\circ} \mathrm{C}\end{array}$ & $90.6 \%$ & [188] \\
\hline & & agitation speed = $120 \mathrm{rpm}$ & - & \\
\hline Bacillus subtilis & Endosulfan & $\begin{array}{c}\mathrm{pH}=6.5, \mathrm{Ci}=50 \mathrm{mg} / \mathrm{L} \\
\mathrm{t}=7 \text { days, } \mathrm{T}=30^{\circ} \mathrm{C}\end{array}$ & $94.2 \%$ & [208] \\
\hline & & agitation speed = $130 \mathrm{rpm}$ & - & \\
\hline Bacillus subtilis & Endosulfan & $\begin{array}{l}\mathrm{pH}=7, \mathrm{Ci}=10 \mathrm{mg} / \mathrm{L} \\
\mathrm{t}=35 \text { days }, \mathrm{T}=30^{\circ} \mathrm{C}\end{array}$ & $94.5 \%$ & [189] \\
\hline & & agitation speed = $130 \mathrm{rpm}$ & - & \\
\hline Stenotronhomongs on strain W7N-1 & decahromedinhenylether (BDF 209) & $\mathrm{pH}=5, \mathrm{Ci}=65 \mu \mathrm{g} / \mathrm{L}$ & $55.15 \%$ & [149] \\
\hline Stenotrophomonas sp. strain WZN-1 & decabromodiphenyl ether (BDE 209) & $\mathrm{t}=30$ days, $\mathrm{T}=25^{\circ} \mathrm{C}$ & - & {$[149]$} \\
\hline Pseudomonas aeruginosa & decabromodiphenyl ether (BDE 209) & $\begin{array}{c}\mathrm{pH}=7.5, \mathrm{Ci}=1 \mathrm{mg} / \mathrm{L} \\
\mathrm{t}=7 \text { days }, \mathrm{T}=30^{\circ} \mathrm{C}\end{array}$ & $56 \%$ & [150] \\
\hline & & agitation speed = $150 \mathrm{rpm}$ & - & \\
\hline Pseudomonas sp. strain HB01 & $\gamma$-hexabromocyclododecane & $\begin{array}{c}\mathrm{pH}=7, \mathrm{Ci}=1 \mathrm{mM} \\
\mathrm{t}=5 \text { days, } \mathrm{T}=28^{\circ} \mathrm{C}\end{array}$ & $81 \%$ & [190] \\
\hline & & agitation speed $=150 \mathrm{rpm}$ & - & \\
\hline & & & $95 \%$ & \\
\hline Pseudoxanthomonas sp. & $\begin{array}{l}\text { 1,1,1-trichloro-2,2-bis(p- } \\
\text { chlorophenyl)ethane }\end{array}$ & $\begin{aligned} \mathrm{pH} & =7.5, \mathrm{Ci}=20 \mathrm{mg} / \mathrm{L} \\
\mathrm{t} & =72 \mathrm{~h}, \mathrm{~T}=30^{\circ} \mathrm{C}\end{aligned}$ & $\begin{array}{l}- \\
-\end{array}$ & [165] \\
\hline & (DDT) & agitation speed = $150 \mathrm{rpm}$ & - & \\
\hline Achromobacter xylosoxidans GYP4 & 2,2,4,4 -tetrabromodiphenyl ether & $\begin{array}{l}\mathrm{pH}=4, \mathrm{Ci}=1 \mathrm{mg} / \mathrm{L} \\
\mathrm{t}=4 \text { days, } \mathrm{T}=30^{\circ} \mathrm{C}\end{array}$ & $90.8 \%$ & [198] \\
\hline & & agitation speed $=150 \mathrm{rpm}$ & - & \\
\hline Pseudomonas fluorescens & Pentachloronhenol & $\mathrm{pH}=8.5, \mathrm{Ci}=250 \mathrm{mg} / \mathrm{L}$ & $99.9 \%$ & {$[100]$} \\
\hline 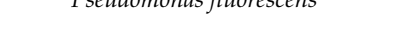 & 1 Entacinoropilentior & agitation speed $=160 \mathrm{rpm}$ & - & {$[199]$} \\
\hline
\end{tabular}


Table 4. Cont

\begin{tabular}{|c|c|c|c|c|}
\hline Microorganism & POPs & Optimal Conditions & $\begin{array}{l}\text { Efficiency/ } \\
\text { Sorption } \\
\text { Capacity }\end{array}$ & Ref. \\
\hline \multirow{2}{*}{ Janibacter sp. FAS23 } & \multirow{2}{*}{ Pentachlorophenol } & \multirow{2}{*}{$\begin{aligned} \mathrm{pH} & =6.9, \mathrm{Ci}=20 \mathrm{mg} / \mathrm{L} \\
\mathrm{t} & =144 \mathrm{~h}, \mathrm{~T}=30^{\circ} \mathrm{C}\end{aligned}$} & $99.06 \%$ & \multirow{2}{*}{ [167] } \\
\hline & & & - & \\
\hline \multirow{4}{*}{ Bacillus cereus HWB1 } & \multirow{2}{*}{ 4-Chlorophenol } & \multirow{4}{*}{$\begin{array}{c}\mathrm{pH}=7, \mathrm{Ci} \text { 4-chlorophenol }=150 \mathrm{mg} / \mathrm{L}, \mathrm{Ci} \\
\text { 4-nitrophenol }=85 \mathrm{mg} / \mathrm{L} \\
\mathrm{t}=5 \text { and } 3 \text { days, } \mathrm{T}=30^{\circ} \mathrm{C} \\
\text { agitation speed }=150 \mathrm{rpm}\end{array}$} & $100 \%$ & \multirow{8}{*}{ [166] } \\
\hline & & & - & \\
\hline & \multirow{2}{*}{ 4-Nitrophenol } & & $78 \%$ & \\
\hline & & & - & \\
\hline \multirow{4}{*}{ Pseudomonas taiwanensis ECAe22 } & \multirow[b]{2}{*}{ 4-Chlorophenol } & \multirow{4}{*}{$\begin{array}{c}\mathrm{pH}=8.5, \mathrm{Ci} \text { 4-chlorophenol }=150 \mathrm{mg} / \mathrm{L}, \mathrm{Ci} \\
\text { 4-nitrophenol }=85 \mathrm{mg} / \mathrm{L}, \\
\mathrm{t}=5 \text { and } 3 \text { days, } \mathrm{T}=30{ }^{\circ} \mathrm{C} \\
\text { agitation speed }=150 \mathrm{rpm}\end{array}$} & $61 \%$ & \\
\hline & & & - & \\
\hline & \multirow[b]{2}{*}{ 4-Nitrophenol } & & $100 \%$ & \\
\hline & & & - & \\
\hline \multirow{2}{*}{$\begin{array}{l}\text { Pseudomonas } \\
\text { aeruginosa HS9 }\end{array}$} & \multirow{2}{*}{ Hexabromocyclododecanes } & \multirow{2}{*}{$\begin{array}{l}\mathrm{pH}=8, \mathrm{Ci}=1.7 \mathrm{mg} / \mathrm{L} \\
\mathrm{t}=14 \text { days }, \mathrm{T}=30^{\circ} \mathrm{C}\end{array}$} & $69 \%$ & \multirow{2}{*}{ [146] } \\
\hline & & & - & \\
\hline \multirow[t]{2}{*}{ Stenotrophomonas maltophilia OG2 } & \multirow{2}{*}{ Endosulfan } & \multirow{2}{*}{$\begin{array}{c}\mathrm{pH}=8, \mathrm{Ci}=100 \mathrm{mg} / \mathrm{L} \\
\mathrm{t}=10 \text { days }, \mathrm{T}=30^{\circ} \mathrm{C} \\
\text { agitation speed }=150 \mathrm{rpm}\end{array}$} & $81.53 \%$ & \multirow{2}{*}[151]{} \\
\hline & & & - & \\
\hline & & FUNGI & & \\
\hline \multirow{2}{*}{ Candida sp. VITJzN04 } & & $\mathrm{pH}=7, \mathrm{Ci}=600 \mathrm{mg} / \mathrm{L}, \mathrm{t}=6$ days, & $100 \%$ & \\
\hline & Lindane & $\mathrm{T}=30^{\circ} \mathrm{C}$, agitation speed $120 \mathrm{rpm}$ & - & [174] \\
\hline & & $\mathrm{pH}=6, \mathrm{Ci}=600 \mathrm{mg} / \mathrm{L}, \mathrm{t}=10$ days, & $100 \%$ & \\
\hline Rhodotorula sp. VITJzN03 & Lindane & $\mathrm{T}=30^{\circ} \mathrm{C}$, agitation speed $120 \mathrm{rpm}$ & - & [168] \\
\hline Fusarium verticillioides AT-100 & Lindane & $\begin{array}{l}\mathrm{pH}=7, \mathrm{Ci}=100 \mathrm{mg} / \mathrm{L} \\
\mathrm{t}=264 \mathrm{~h}, \mathrm{~T}=30 \pm 2{ }^{\circ} \mathrm{C}\end{array}$ & $86 \%$ & [148] \\
\hline & & agitation speed $=120 \mathrm{rpm}$ & - & \\
\hline & & $\mathrm{Ci}=13.2 \mu \mathrm{M}, \mathrm{t}=10$ days, & $90 \%$ & \\
\hline Mucor racemosus strain DDF & Dieldrin & $\mathrm{T}=25^{\circ} \mathrm{C}$ & - & \\
\hline & & & $53.3 \%$ & \\
\hline & $\alpha$-endosulfan & & - & \\
\hline 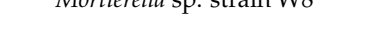 & R-ondoculfan & & $11.1 \%$ & \\
\hline & B-endosulfan & $\mathrm{Ci}=8.2 \mu \mathrm{M}, \mathrm{t}=14$ days, $\mathrm{T}=25^{\circ} \mathrm{C}$ & - & [195] \\
\hline & vond & & $47.2 \%$ & \\
\hline & $\alpha$-endosulfan & & - & \\
\hline Mortterella sp. strain Cml-45 & & & $25.1 \%$ & \\
\hline & $\beta$-endosultan & & - & \\
\hline Trichodomma rivide & & & $92 \%$ & \\
\hline Trichoderma viride & Dicofol & $\mathrm{pH}=7, \mathrm{Ci}=100 \mathrm{mg} / \mathrm{L}$ & - & [184] \\
\hline Trichoderma harzianum & & $\mathrm{t}=28$ days, $\mathrm{T}=27 \pm 1^{\circ} \mathrm{C}$ & $96 \%$ & \\
\hline Trichoderma harzianum & & & - & \\
\hline Penicillium shrusogenum & & & $69.4 \%$ & \\
\hline Pentciltum criysogentum & & & - & \\
\hline Asneroillus flazus & Endosulfan & $\begin{array}{c}\mathrm{pH}=5.6 \pm 0.2, \mathrm{Ci}=10 \mathrm{mg} / \mathrm{L}, \\
\mathrm{t}=35 \text { days }, \mathrm{T}=30^{\circ} \mathrm{C},\end{array}$ & $72.3 \%$ & [189] \\
\hline Asperginlus flaous & & agitation speed = $130 \mathrm{rpm}$ & - & \\
\hline Acnoroilluc nioper & & & $77.2 \%$ & \\
\hline Aspergillus niger & & & - & \\
\hline Rhodotorula sn NS01 & Benzo[alnvrene & $\mathrm{Ci}=10 \mathrm{mg} / \mathrm{L}, \mathrm{t}=7$ days & $52 \%$ & \\
\hline Rhodotorula sp. NSU1 & Benzo[a]pyrene & $\mathrm{T}=30^{\circ} \mathrm{C}$, agitation speed $120 \mathrm{rpm}$ & - & [200] \\
\hline Candida tronicalis W1 & 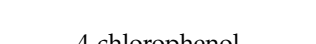 & $C \mathrm{i}-150 \mathrm{mg} / \mathrm{I} t-20 \mathrm{~b}-\mathrm{T}-30^{\circ} \mathrm{C}$ & $100 \%$ & {$[2011$} \\
\hline Candida tropicalis WI & 4-chlorophenol & $\mathrm{C} 1=150 \mathrm{mg} / \mathrm{L}, \mathrm{t}=20 \mathrm{~h}, \mathrm{l}=30^{\circ} \mathrm{C}$ & - & [201] \\
\hline I asiodinlodia theohromae & Benzo[alnvrene & $\mathrm{Ci}=100 \mathrm{mg} / \mathrm{L}, \mathrm{t}=10$ days, $\mathrm{T}=30^{\circ} \mathrm{C}$, agitation & $53.0 \pm 0.9 \%$ & {$[193]$} \\
\hline Lasiodiplodia theobromae & Benzo[a]pyrene & speed $150 \mathrm{rpm}$ & - & [193] \\
\hline Cunninghamella sp. UMAS SD12 & Pentachloronhenol & $\mathrm{nH}-55 \mathrm{Ci}-20 \mathrm{~mol}+\mathrm{t}-15$ d2us $\mathrm{T}-20^{\circ} \mathrm{C}$ & $51.7 \%$ & 071 \\
\hline & Pentachlorophenol & $\mathrm{pH}=5.5, \mathrm{C} 1=20 \mathrm{mg} / \mathrm{L}, \mathrm{t}=15$ days, $1=28{ }^{\circ} \mathrm{C}$ & - & [197] \\
\hline
\end{tabular}


Table 5. Persistent organic pollutant removal by inactive microbial biomass.

\begin{tabular}{|c|c|c|c|c|}
\hline Microorganism & POPs & Optimal Conditions & $\begin{array}{l}\text { Efficiency/ } \\
\text { Sorption } \\
\text { Capacity }\end{array}$ & Ref. \\
\hline \multirow{2}{*}{ Escherichia coli } & \multirow{8}{*}{ Lindane } & \multirow{8}{*}{$\begin{aligned} \mathrm{Ci}=4 \mathrm{mg} / \mathrm{L}, \mathrm{T} & =20^{\circ} \mathrm{C} \\
\mathrm{D}=4 \mathrm{~g} / \mathrm{L}, \mathrm{t} & =4 \mathrm{~h} \\
\text { agitation speeed } & =250 \mathrm{rpm}\end{aligned}$} & - & \multirow{8}{*}{ [140] } \\
\hline & & & $0.5 \mathrm{mg} / \mathrm{g}$ & \\
\hline \multirow{2}{*}{ Zoogloea ramigera } & & & - & \\
\hline & & & $2.8 \mathrm{mg} / \mathrm{g}$ & \\
\hline \multirow{2}{*}{ Bacillus megaterium } & & & - & \\
\hline & & & $0.7 \mathrm{mg} / \mathrm{g}$ & \\
\hline \multirow{2}{*}{ Bacillus subtilis } & & & - & \\
\hline & & & $0.6 \mathrm{mg} / \mathrm{g}$ & \\
\hline \multirow{6}{*}{$\begin{array}{l}\text { Emericella nidulans } \\
\text { Penicillium miczynskii }\end{array}$} & \multirow{2}{*}{ 2,4-Dichlorophenoxyacetic acid } & \multirow{6}{*}{$\begin{array}{l}\mathrm{Ci}=0.12,0.25,0.5 \text { and } 1 \mathrm{mM}, \\
\mathrm{T}=20^{\circ} \mathrm{C}, \mathrm{D}=10 \mathrm{~g} / \mathrm{L}, \mathrm{t}=3 \mathrm{~h}\end{array}$} & $70 \%$ & \multirow{6}{*}{ [144] } \\
\hline & & & - & \\
\hline & \multirow{2}{*}{ 2,4-Dichlorophenol } & & $70 \%$ & \\
\hline & & & - & \\
\hline & \multirow{2}{*}{ 4-Chlorophenol } & & $50 \%$ & \\
\hline & & & - & \\
\hline \multirow{4}{*}{ 130Rhizopus oryzae } & \multirow{4}{*}{ Lindane } & \multirow{2}{*}{$\begin{array}{l}\mathrm{pH}=7, \mathrm{Ci}=0.1 \mathrm{mg} / \mathrm{L}, \mathrm{T}=18^{\circ} \mathrm{C}, \mathrm{t}=250 \\
\mathrm{~min}, \mathrm{D}=8 \mathrm{~g} / \mathrm{L}, \text { biomass age }=1-7 \text { days }\end{array}$} & $90.2 \%$ & \multirow{2}{*}{ [142] } \\
\hline & & & - & \\
\hline & & \multirow{2}{*}{$\begin{array}{c}\mathrm{pH}=7, \mathrm{Ci}=200 \mu \mathrm{g} / \mathrm{L}, \mathrm{T}=30^{\circ} \mathrm{C}, \text { agitation } \\
\text { speed }=120 \mathrm{rpm}, \mathrm{t}=5 \mathrm{~h}, \mathrm{D}=1.67 \mathrm{~g} / \mathrm{L} \\
\text { biomass age }=1-7 \text { days }\end{array}$} & $107.5 \mu \mathrm{g} / \mathrm{g}$ & \multirow[t]{2}{*}{ [209] } \\
\hline & & & - & \\
\hline \multirow{6}{*}{ Rhizopus arrhizu } & \multirow{2}{*}{ Lindane } & \multirow{6}{*}{$\begin{array}{c}\mathrm{Ci}=1 \mathrm{mg} / \mathrm{L}, \mathrm{T}=20^{\circ} \mathrm{C} \\
\mathrm{D}=4 \mathrm{~g} / \mathrm{L}, \mathrm{t}=3 \text { days, } \\
\text { agitation speeed }=250 \mathrm{rpm}\end{array}$} & $2.7 \mathrm{mg} / \mathrm{g}$ & \multirow{6}{*}{ [141] } \\
\hline & & & - & \\
\hline & 2-Chlorobiphenyl & & $11.1 \mathrm{mg} / \mathrm{g}$ & \\
\hline & z-Cniorobipnenyi & & - & \\
\hline & \multirow{2}{*}{ Pentachlorophenol } & & $14.9 \mathrm{mg} / \mathrm{g}$ & \\
\hline & & & - & \\
\hline \multirow{2}{*}{ Mucor racemosus } & \multirow{6}{*}{ Pentachloronitrobenzene } & \multirow{6}{*}{$\begin{array}{c}\mathrm{Ci}=250 \mathrm{mg} / \mathrm{L}, \\
\mathrm{T}=21^{\circ} \mathrm{C}, \mathrm{D}=10 \mathrm{~g} / \mathrm{L}, \mathrm{t}=6 \mathrm{~h} \text {, agitation } \\
\text { speeed }=180 \mathrm{rpm}\end{array}$} & $5.1 \mathrm{mg} / \mathrm{g}$ & \multirow{6}{*}[210]{} \\
\hline & & & - & \\
\hline Rhizopus arrhizus & & & $4.6 \mathrm{mg} / \mathrm{g}$ & \\
\hline Клtzopus armtzus & & & - & \\
\hline \multirow{2}{*}{ Sporothrix cyanescens } & & & $2.6 \mathrm{mg} / \mathrm{g}$ & \\
\hline & & & - & \\
\hline \multirow[t]{2}{*}{$\begin{array}{c}\text { Mycobacterium } \\
\text { chlorophenolicum PCP-1 }\end{array}$} & Pentachlorophenol & $\begin{aligned} \mathrm{pH}=7, \mathrm{Ci}= & 50 \mathrm{mg} / \mathrm{L}, \mathrm{T}=30^{\circ} \mathrm{C}, \text { agitation } \\
& \text { speed }=120 \mathrm{rpm},\end{aligned}$ & $\sim 90 \mu \mathrm{mol} / \mathrm{g}$ & [29] \\
\hline & & $\mathrm{t}=1.5 \mathrm{~min}, \mathrm{D}=0.12 \mathrm{~g} / \mathrm{L}$ & - & \\
\hline
\end{tabular}

$\mathrm{Ci}=$ initial concentration of POP in solution, $\mathrm{t}=$ contact time, $\mathrm{T}=$ temperature.

\section{Key Considerations and Future Perspectives for Process Scale-Up}

The performance that various living or dead microorganism species have shown in removing of POPs and heavy metals makes them promising alternatives for removing of these types of pollutants from liquid media. Since in real media a consortium of microorganisms is available, some bioremediation studies [211] showed that the process is more efficient using simultaneous microbial strains instead of one single species. Advances in genetically modified microbes engineering, microbial fuel cells-based techniques, biofilmmediated techniques suggest that bioremediation technologies would be very promising 
in the near future [212]. Biosorption potential has been performed at laboratory and pilot scales even using real wastewater effluents [20,213].

However, the majority of the studies are performed under laboratory conditions, and futher studies are needed to facilitate upscaling of lab scale options to industrial scale applications, considering both environmental and economic criteria. In spite of the fact that some commercial biosorbents are available for biosorption of HMs ions (e.g., AlgaSORB, Bio-Fix, B.V.SORBEX), there is no trend in adoption of biosorption as a wastewater treatment technology [214]. For further details on these biosorbents please see the paper of Kanamarlapudi et al. [214]. Previous to commercial application, biosorbents should fulfill some specific conditions in order to be optimum and standardized to different effluent type. The economic feasibility and the environmental impact in terms of largescale application are necessary to be considered [214]. Also, an integrated approach for obtaining multiple energy as well as non-energy products, including biosorbents, can be developed for a more sustainable and profitable use of the microbial biomass. In this sense, the design of the scale-up processes can be carried out based on a similar flowsheet as the one described by Qamouche et al. [215].

In this regard, sustainable application of biosorption and bioaccumulation processes can be expanded on a larger scale requiring different mindset and new approaches. In research projects there is an increasingly demand in terms of sustainability dimension of new processes from the beginning stages (design phase, before implementation) [216]. The microbial process scale-up can be seen as a new perspective from the environmental impact evaluation point of view. In this regard, the use of microorganism for removal of environmental pollutants from contaminated media is considered an efficient and ecofriendly process [70].

Crater and Lievense [217] stated that "in scaling up microbial processes, it is clearly impactful to get it right and to get it right the first time". They also provided three guiding principles as a basis in scale up such as: start with the end in mind; be operose with details; be aware of the unexpected [217]. To save the risks of failure during process scale-up an important approach is the scientific part, which gives the opportunity to change any process and also reduces cost of implementation [218]. The scientific database comprises some analysis that can be used in the scale-up processes such us: life cycle assessment (LCA), life cycle costs (LCC) and social.

Life cycle assessment (LCA) analysis is widely used for processes or product systems at different development stages: for a process/product already developed, or at early design stage. In the scale-up process this analysis is defined as ex-ante LCA, due to the capacity of giving a potential impact of the new process before implementation [219]. The scale-up through LCA methodology follows three important steps [219] as represented in Figure 8 .

As it was already mentioned, the scientific database is very important in this process, to identify the production scale and maturity of the production system, which is the first step in scale-up process. The scientific database collection started from the laboratory scale studies where the chemical reaction behavior as well as temperature, pressure and other important parameters are determined [220]. In biosorption and bioaccumulation process some of these parameters are of high importance (as already was discussed in Sections 3.2 and 4.2).

In the second stage, the proposed system is described and defined for the LCA development. First, the life cycle impact (LCI) is elaborated, then the life cycle impact assessment (LCIA) is performed. The scale-up process is described in the last stage, based on a comparative analysis derived from LCA results. The third stage defines the most significant factors responsible for inconsistencies between laboratory scale and large scale, which can be adapted to the new scale [221]. 


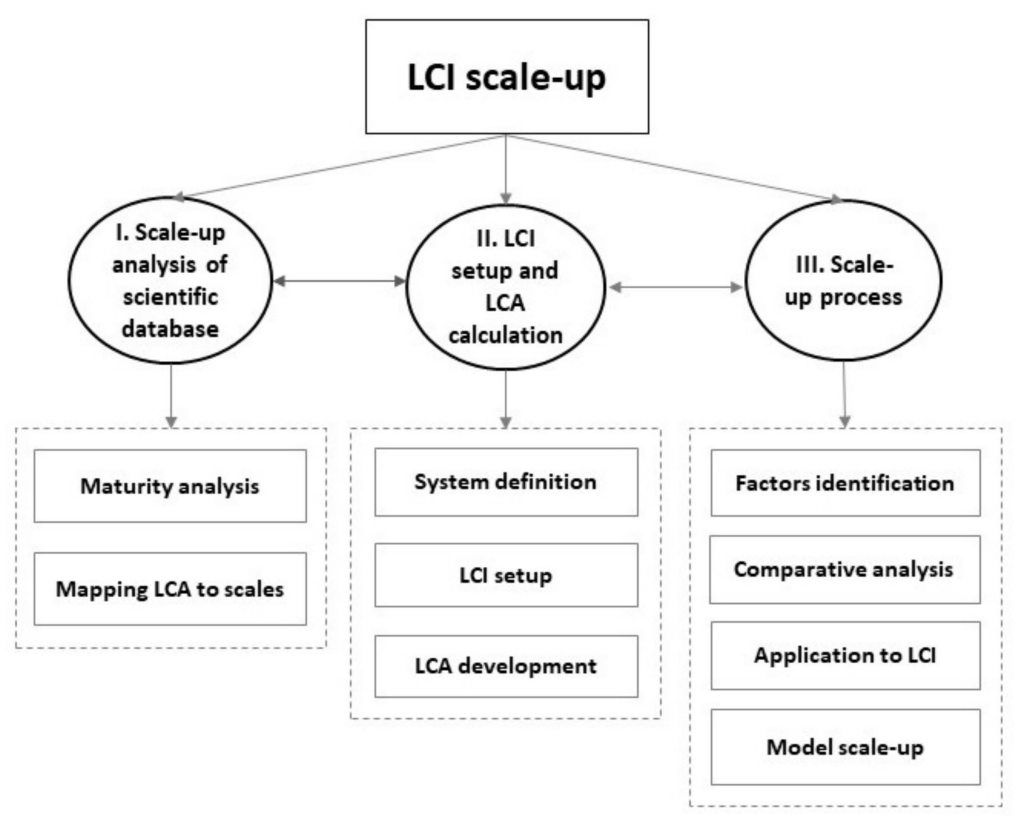

Figure 8. LCI scale-up methodology.

From our knowledge, the scale-up of microbial process is a quite new approach, especially in line with the environmental criteria. However, there are some studies that debate the scale-up concept from a laboratory scale to industrial one considering LCA approach. For example, Piccinno et al. [216] in their study analyzed the impact of a chemical process at industrial scale. They considered an advanced stage of the process (a pilot plant) to simulate a chemical process scale-up by using the same apparatus and connection in all the steps. They proposed five-steps for the scale-up framework to perform LCA analysis: laboratory protocol, plant flow chart considering scale and reactor size, separate scale-up of each process step and linkage of process steps. In conclusion, this approach was relatively simple and efficient to provide the potential impacts of chemical process at industrial level. Later, Crater and Lievense [217] proposed the scale-up of an industrial microbial processes, involving cultivation of microbes in bioreactors (fermentation). They started from the idea that scale-up should be realized in two phases to minimize the risk of full-scale manufacturing plant (capital investment), validation process, the supply chain and market demand. After analysis, some important key challenges for a successful scale-up were pointed out, namely that it is very important to have technical support during all phases and the laboratory or pilot plant has to be validated. According with Ghiron et al. [222], it is important to stress towards the potential of evaluating environmental feasibility of a new process based on lab and pilot-scale results.

\section{Conclusions}

The majority of HMs and POPs are very toxic to both human and environment. Water is one of the most important natural resource which is severely affected especially by anthropogenic pollution. Thus, different strategies are currently available for remediation of polluted-water bodies. Bioremediation is considered one of the most proper alternatives dealing with polluted sites. In this regard, a diversity of microbial strains proved to have an important potential to remove both heavy metals and persistent organic pollutants from liquid mediums. The potential of microorganisms to remove or reduce these contaminants lies first of all in the complex and diverse mechanisms involved at extracellular and intracellular level. Thus, in order to tolerate and remove the toxic pollutants, the microorganisms are able to transform POPs through co-metabolism, biomineralization, extracellular biodegradation and other mechanisms mediated by various enzymes and substances secreted by cells. By reduction, oxidation, hydrolysis, dehalogenation and methylation reactions catalyzed by enzymes, the POPs lead to a complete or partial miner- 
alization. The results of these reactions consist in a wide variety of metabolites less complex and less toxic, $\mathrm{CO}_{2}$ and energy. In case of the removal of $\mathrm{HMs}$, the main mechanisms involved are biosorption, bioaccumulation, biotransformation, bioprecipitation, metal reduction, proton volatilization release, biomethylation, and chelation by ionic and covalent interaction. An important role is also played by the synthesis of the extracellular polymeric substances, which facilitate these processes.

Biosorption (a passive mechanism) has been shown to be generally a rapid process and to provide a better sorption capacity compared to bioaccumulation (active mechanism). Biosorption process depends on several experimental conditions (temperature, $\mathrm{pH}$, contact time and agitation speed), pollutant type and its initial concentration and other factors.

Although important progress has been made in selecting the proper microorganisms for the decontamination of polluted waters, some issues still need to be addressed. For example, microbial genetic engineering proved to increase the capacity of microorganism to tolerate and accumulate HMs. Moreover, immobilizations of microbial biomass in polymeric matrixes may increase its capacity and resistance to chemicals or may provide better mechanical strength and optimum porosity.

The feasibility of the process at large scale is still not fully demonstrated and nowadays, there is no trend in adoption of biosorption in current wastewater treatment practice. Further studies are needed to demonstrate the technological feasibility and environmental performance at large scale application. In this regard, a sustainable scale-up process should be considered by applying LCA methodology which is a new approach that should be used in the evaluation of the commercial up-scaling of biosorption and bioaccumulation processes considered for the remediation of polluted-water bodies. In the scale-up process this analysis is defined as ex-ante LCA, due to the capacity of giving a potential impact of the new process before implementation. Finally, for a sustainable scale-up it is necessary to consider all the necessary data starting from the design phase to the end of the process for a potential expansion in the near future.

Author Contributions: Conceptualization, R.M.H., C.F., M.R., P.C.; validation, R.M.H., P.C., M.G.; formal analysis, C.F., M.R., I.M.S., M.A.; investigation, C.F., M.R., I.M.S., M.A.; writing—original draft preparation, C.F., M.R., R.M.H., P.C., I.M.S., M.A.; writing-review and editing, R.M.H., P.C., M.G.; supervision, R.M.H., P.C.; project administration, R.M.H.; funding acquisition, R.M.H.; C.F. and M.R. contributed equally to this work. All authors have read and agreed to the published version of the manuscript.

Funding: This work was supported by a grant of the Romanian Ministry of Research, Innovation and Digitization, CNCS/CCCDI - UEFISCDI, project number PN-III-P2-2.1-PED-2019-2430, contract no. 439 PED/2020, within PNCDI III.

Institutional Review Board Statement: Not applicable.

Informed Consent Statement: Not applicable.

Acknowledgments: "Ion Ionescu de la Brad" Iasi University of Life Sciences, Romania is highly acknowledged for its continuous support during the implementation of the SusTrEE project.

Conflicts of Interest: The authors declare no conflict of interest. The funders had no role in the design of the study; in the collection, analyses, or interpretation of data; in the writing of the manuscript, or in the decision to publish the results.

\section{References}

1. Fernández, P.M.; Viñarta, S.C.; Bernal, A.R.; Cruz, E.L.; Figueroa, L.I. Bioremediation strategies for chromium removal: Current research, scale-up approach and future perspectives. Chemosphere 2018, 208, 139-148. [CrossRef] [PubMed]

2. Gavrilescu, M. Fate of pesticides in the environment and its bioremediation. Eng. Life Sci. 2005, 5, 497-526. [CrossRef]

3. Frenkel-Pinter, M.; Rajaei, V.; Glass, J.B.; Hud, N.V.; Williams, L.D. Water and life: The medium is the message. J. Mol. Evol. 2021, 89, 2-11. [CrossRef] [PubMed]

4. Ayangbenro, A.S.; Babalola, O.O. A new strategy for heavy metal polluted environments: A review of microbial biosorbents. Int. J. Environ. Res. Public Health 2017, 14, 94. [CrossRef] 
5. Karaouzas, I.; Kapetanaki, N.; Mentzafou, A.; Kanellopoulos, T.D.; Skoulikidis, N. Heavy metal contamination status in Greek surface waters: A review with application and evaluation of pollution indices. Chemosphere 2021, 263, 128192. [CrossRef] [PubMed]

6. Singh, R.L. (Ed.) Principles and Applications of Environmental Biotechnology for a Sustainable Future; Springer: Singapore, 2017; ISBN 978-981-10-1865-7.

7. Vallero, D.A. Persistent, Bioaccumulative, and Toxic Pollutants; McGraw-Hill Professional: National Exposure Research Laboratory, U.S. Environmental Protection Agency: Research Triangle Park, NC, USA, 2015.

8. Guo, W.; Pan, B.; Sakkiah, S.; Yavas, G.; Ge, W.; Zou, W.; Tong, W.; Hong, H. Persistent Organic Pollutants in Food: Contamination Sources, Health Effects and Detection Methods. Int. J. Environ. Res. Public Health 2019, 16, 4361. [CrossRef]

9. Cara, I.G.; Topa, D.; Calistru, A.E.; Motrescu, I.; Bulgariu, L.; Jitareanu, G. Agri-wastes as a low-cost adsorbent for nico-sulfuron herbicide. Environ. Eng. Manag. J. 2020, 19, 335-343.

10. Rigét, F.; Bignert, A.; Braune, B.; Stow, J.; Wilson, S. Temporal trends of legacy POPs in Arctic biota, an update. Sci. Total Environ. 2010, 408, 2874-2884. [CrossRef]

11. Carlsson, P.; Herzke, D.; Kallenborn, R. Polychlorinated biphenyls (PCBs), polybrominated diphenyl ethers (PBDEs) and perfluorinated alkylated substances (PFASs) in traditional seafood items from western Greenland. Environ. Sci. Pollut. Res. 2013, 21, 4741-4750. [CrossRef]

12. Yi, Y.; Yang, Z.; Zhang, S. Ecological risk assessment of heavy metals in sediment and human health risk assessment of heavy metals in fishes in the middle and lower reaches of the Yangtze River basin. Environ. Pollut. 2011, 159, 2575-2585. [CrossRef]

13. Banerjee, A.; Sarkar, P.; Banerjee, S. Application of statistical design of experiments for optimization of As(V) biosorption by immobilized bacterial biomass. Ecol. Eng. 2016, 86, 13-23. [CrossRef]

14. Kumar, V.; Sharma, A.; Pandita, S.; Bhardwaj, R.; Thukral, A.; Cerda, A. A review of ecological risk assessment and associated health risks with heavy metals in sediment from India. Int. J. Sediment Res. 2020, 35, 516-526. [CrossRef]

15. Barletta, M.; Lima, A.R.A.; Costa, M.F. Distribution, sources and consequences of nutrients, persistent organic pollutants, metals and microplastics in South American estuaries. Sci. Total Environ. 2019, 651, 1199-1218. [CrossRef]

16. WHO. Persistent Organic Pollutants (POPS) Training Module; World Health Organization: Geneva, Switzerland, 2008.

17. Gavrilescu, M.; Diaconu, M.; Bulgariu, L.; Volf, I.; Catrinescu, C.; Smaranda, C.; Cozma, P.; Hlihor, R.-M.; Ghinea, C.; Apostol, L.C.; et al. Exploring and Exploiting the Abilities of Microorganisms and Plants and Their Interactions for Environmental Bioremediation (in Romanian); Performantica Publishing House: Iasi, Romania, 2019.

18. Ungureanu, C.V.; Favier, L.; Bahrim, G.E. Improving Biodegradation of Clofibric Acid by Trametes pubescens through the Design of Experimental Tools. Microorganisms 2020, 8, 1243. [CrossRef]

19. Favier, L.; Ungureanu, C.V.; Simion, A.I.; Bahrim, G.; Vial, C. Enhancing the biodegradation efficiency of a emergent refractory water pollutant by a bacterial isolate through a statistical process optimization approach. Process. Saf. Environ. Prot. 2021, 148, 1133-1145. [CrossRef]

20. Ibrahim, W.M. Biosorption of heavy metal ions from aqueous solution by red macroalgae. J. Hazard. Mater. 2011, 192, 1827-1835. [CrossRef]

21. Chojnacka, K. Biosorption and bioaccumulation-The prospects for practical applications. Environ. Int. 2010, 36, 299-307. [CrossRef]

22. Liao, C.; Liu, Y.-P.; Ren, H.; Jiang, X.-Y.; Yu, J.-G.; Chen, X.-Q. Rational assembly of GO-based heterocyclic sulfur- and nitrogencontaining aerogels and their adsorption properties toward rare earth elementals. J. Hazard. Mater. 2021, 419, 126484. [CrossRef] [PubMed]

23. Timková, I.; Sedláková-Kaduková, J.; Pristaš, P. Biosorption and Bioaccumulation Abilities of Actinomycetes/Streptomycetes Isolated from Metal Contaminated Sites. Separations 2018, 5, 54. [CrossRef]

24. Derco, J.; Vrana, B. (Eds.) Introductory Chapter: Biosorption; InTech: Rijeka, Croatia, 2018; ISBN 978-1-78923-472-5.

25. Sandrin, T.R.; Maier, R. Impact of metals on the biodegradation of organic pollutants. Environ. Health Perspect. 2003, 111, 1093-1101. [CrossRef]

26. Agoro, M.A.; Adeniji, A.O.; Adefisoye, M.A.; Okoh, O.O. Heavy metals in wastewater and sewage sludge from selected municipal treatment plants in eastern cape province, South Africa. Water 2020, 12, 2746. [CrossRef]

27. Kamashwaran, S.R.; Crawford, D.L. Anaerobic biodegradation of pentachlorophenol in mixtures containing cadmium by two physiologically distinct microbial enrichment cultures. J. Ind. Microbiol. Biotechnol. 2001, 27, 11-17. [CrossRef] [PubMed]

28. Daneshvar, E.; Zarrinmehr, M.J.; Kousha, M.; Hashtjin, A.M.; Saratale, G.D.; Maiti, A.; Vithanage, M.; Bhatnagar, A. Hexavalent chromium removal from water by microalgal-based materials: Adsorption, desorption and recovery studies. Bioresour. Technol. 2019, 293, 122064. [CrossRef]

29. Brandt, S.; Zeng, A.-P.; Deckwer, W.-D. Adsorption and desorption of pentachlorophenol on cells of mycobacterium chlorophenolicum PCP-1. Biotechnol. Bioeng. 1997, 55, 480-489.

30. DalCorso, G.; Manara, A.; Piasentin, S.; Furini, A. Nutrient metal elements in plants. Metallomics 2014, 6, 1770-1788. [CrossRef] [PubMed]

31. Hansda, A.; Kumar, V. A comparative review towards potential of microbial cells for heavy metal removal with emphasis on biosorption and bioaccumulation. World J. Microbiol. Biotechnol. 2016, 32, 170. [CrossRef] [PubMed] 
32. Leong, Y.K.; Chang, J.-S. Bioremediation of heavy metals using microalgae: Recent advances and mechanisms. Bioresour. Technol. 2020, 303, 122886. [CrossRef] [PubMed]

33. Yin, K.; Wang, Q.; Lv, M.; Chen, L. Microorganism remediation strategies towards heavy metals. Chem. Eng. J. 2019, 360, 1553-1563. [CrossRef]

34. Salam, K.A. Towards sustainable development of microalgal biosorption for treating effluents containing heavy metals. Biofuel Res. J. 2019, 6, 948-961. [CrossRef]

35. Torres, E. Biosorption: A review of the latest advances. Processes 2020, 8, 1584. [CrossRef]

36. Gaur, N.; Narasimhulu, K.; PydiSetty, Y. Recent advances in the bio-remediation of persistent organic pollutants and its effect on environment. J. Clean. Prod. 2018, 198, 1602-1631. [CrossRef]

37. Bajaj, S.; Singh, D.K. Biodegradation of persistent organic pollutants in soil, water and pristine sites by cold-adapted microorganisms: Mini review. Int. Biodeterior. Biodegrad. 2015, 100, 98-105. [CrossRef]

38. Azeh Engwa, G.; Udoka Ferdinand, P.; Nweke Nwalo, F.N.; Unachukwu, M. Mechanism and Health Effects of Heavy Metal Toxicity in Humans. In Poisoning in the Modern World-New Tricks for an Old Dog? Karcioglu, O., Arslan, B., Eds.; IntechOpen: Rijeka, Croatia, 2019; ISBN 978-1-83880-785-6.

39. Masindi, V.; Muedi, K.L. Environmental contamination by heavy metals. In Heavy Metals; Saleh, H.E.D.M., Aglan, R., Eds.; InTech: Rijeka, Croatia, 2018; ISBN 978-1-78923-360-5.

40. Diganta, M.T.M.; Sharmi, T.T.; Saifullah, A.; Uddin, M.J.; Sajib, A.M. Appraisal of heavy metal contamination in road dust and human health risk in a municipality of Bangladesh. Environ. Eng. Manag. J. 2020, 19, 2165-2177. [CrossRef]

41. Wood, J.L.; Liu, W.; Tang, C.; Franks, A.E. Microorganisms in heavy metal bioremediation: Strategies for applying microbialcommunity engineering to remediate soils. AIMS Bioeng. 2016, 3, 211-229. [CrossRef]

42. Shang, D.; Geissler, B.; Mew, M.; Satalkina, L.; Zenk, L.; Tulsidas, H.; Barker, L.; El-Yahyaoui, A.; Hussein, A.; Taha, M.; et al. Unconventional uranium in China's phosphate rock: Review and outlook. Renew. Sustain. Energy Rev. 2021, 140, 110740. [CrossRef]

43. Unesco (Ed.) Wastewater: The Untapped Resource; The United Nations World Water Development Report; UNESCO: Paris, France, 2017; ISBN 978-92-3-100201-4.

44. Algül, F.; Beyhan, M. Concentrations and sources of heavy metals in shallow sediments in Lake Bafa, Turkey. Sci. Rep. 2020, 10, 11782. [CrossRef] [PubMed]

45. Gabrielyan, A.V.; Shahnazaryan, G.A.; Minasyan, S.H. Distribution and identification of sources of heavy metals in the Voghji River basin impacted by mining activities (Armenia). J. Chem. 2018, 2018, 1-9. [CrossRef]

46. Popoola, L.T.; Yusuff, A.S.; Adeoye, B.K.; Aderibigbe, T.A. Cd (II) biosorption using bacterial isolates from sawdust: Optimization via orthogonal array Taguchi method. Water SA 2020, 46, 4. [CrossRef]

47. Kumar, A.; Maleva, M.; Borisova, G.; Chukina, N.; Morozova, M.; Kiseleva, I. Nickel and copper accumulation strategies in Odontarrhena obovata growing on copper smelter-influenced and non-influenced serpentine soils: A comparative field study. Environ. Geochem. Health 2021, 43, 1401-1413. [CrossRef]

48. Fargašová, A. Toxicity comparison of some possible toxic metals ( $\mathrm{Cd}, \mathrm{Cu}, \mathrm{Pb}, \mathrm{Se}, \mathrm{Zn})$ on young seedlings of Sinapis alba $\mathrm{L}$. Plant Soil Environ. 2004, 50, 33-38. [CrossRef]

49. European Environment Agency. Chemicals in European waters. In Knowledge Developments; Publications Office: Luxembourg, 2018.

50. E-PRTR-European Pollutant Release and Transfer Register; European Environment Agency. 2020. Available online: https: / / prtr.eea.europa.eu/\#/home (accessed on 22 November 2020).

51. EEA Environmental Pressures of Heavy Metals Releases from Europe's Industry; European Environment Agency. 2016. Available online: https:/ / www.eea.europa.eu/themes/industry/industrial-pollution-in-europe/heavy-metal-pollution (accessed on 20 November 2020).

52. Smaranda, C.; Hlihor, R.-M.; Apostol, L.C.; Bulgariu, L.; Diaconu, M.; Fortuna, M.E.; Gavrilescu, M. Chapter 2. biosorption and bioaccumulation: Principles and potential applications in bioremediation. In Biosorption and Bioaccumulation: Principles and applications in environmental bioremediation; Politehnium Publishing House: Iasi, Romania, 2016.

53. Rosca, M.; Hlihor, R.-M.; Gavrilescu, M. Bioremediation of persistent toxic substances: From conventional to new approaches in using microorganisms and plants. In Microbial Technology for the Welfare of Society. Microorganisms for Sustainability; Arora, P.K., Ed.; Springer Singapore: Singapore, 2019; Volume 17, pp. 289-312. ISBN 9789811388439.

54. Dos Santos Junior, S.G.; da Rocha Santana, R.M.; de Mendonca Gomes, R.K.; de Moraes, N.F.S.; da Silva, P.M.; Paiva PM, G.; Napoleao, D.C. Treatment of persistent organic pollutants in LED reactor using ferrous sulfate and iron waste for fenton process. Environ. Eng. Manag. J. 2021, 20, 883-893.

55. Miniero, R.; Iamiceli, A.L.; De Felip, E. Persistent Organic Pollutants. In Reference Module in Earth Systems and Environmental Sciences; Elsevier: London, UK, 2015; ISBN 978-0-12-409548-9.

56. All POPs Listed in the Stockholm Convention. Available online: http://www.pops.int/ (accessed on 15 August 2021).

57. The Convention and Its Achievements. A Common Framework for Transboundary Cooperation on Air Pollution. Available online: https://unece.org/convention-and-its-achievements (accessed on 15 August 2021).

58. Zacharia, T.; Degradation, J. Pathways of Persistent Organic Pollutants (POPs) in the environment. In Persistent Organic Pollutants; Donyinah, S.K., Ed.; IntechOpen: Rijeka, Croatia, 2019; ISBN 978-1-78985-807-5. 
59. Ashraf, M.A. Persistent organic pollutants (POPs): A global issue, a global challenge. Environ. Sci. Pollut. Res. 2017, 24, 4223-4227. [CrossRef]

60. Jaspers, V.; Megson, D.; O'Sullivan, G. POPs in the Terrestrial Environment. In Environmental Forensics for Persistent Organic Pollutants; Elsevier BV: Amsterdam, The Netherlands, 2013; pp. 291-356.

61. Lohmann, R.; Breivik, K.; Dachs, J.; Muir, D. Global fate of POPs: Current and future research directions. Environ. Pollut. 2007, 150, 150-165. [CrossRef]

62. El-Kilani, R.M.; Belal, M.H. Modelling an environmental pollutant transport from the stacks to and through the soil. J. Adv. Res. 2010, 1, 243-253. [CrossRef]

63. Cara, I.; Filip, M.; Bulgariu, L.; Raus, L.; Topa, D.; Jitareanu, G. Environmental Remediation of Metribuzin Herbicide by Mesoporous Carbon-Rich from Wheat Straw. Appl. Sci. 2021, 11, 4935. [CrossRef]

64. Filote, C.; Roșca, M.; Hlihor, R.-M. Overview of using living and non-living microorganisms for the removal of heavy metals from wastewaters. Res. J. Agric. Sci. 2020, 52, 22-31.

65. Rosca, M.; Hlihor, R.-M.; Cozma, P.; Comanita, E.-D.; Simion, I.M.; Gavrilescu, M. Potential of biosorption and bioaccumula-tion processes for heavy metals removal in bioreactors. In Proceedings of the 2015 E-Health and Bioengineering Conference (EHB), IEEE, Iasi, Romania, 19-21 November 2015; pp. 1-4.

66. Kurniati, E.; Arfarita, N.; Imai, T.; Higuchi, T.; Kanno, A.; Yamamoto, K.; Sekine, M. Potential bioremediation of mercurycontaminated substrate using filamentous fungi isolated from forest soil. J. Environ. Sci. Chin. 2014, 26, 1223-1231. [CrossRef]

67. Ge, W.; Zamri, D.; Mineyama, H.; Valix, M. Bioaccumulation of heavy metals on adapted Aspergillus foetidus. Adsorption 2011, 17, 901-910. [CrossRef]

68. Michalak, I.; Chojnacka, K.; Witek-Krowiak, A. State of the Art for the Biosorption Process-A Review. Appl. Biochem. Biotechnol. 2013, 170, 1389-1416. [CrossRef]

69. Verma, S.; Kuila, A. Bioremediation of heavy metals by microbial process. Environ. Technol. Innov. 2019, 14, 100369. [CrossRef]

70. Igiri, B.E.; Okoduwa, S.; Idoko, G.O.; Akabuogu, E.P.; Adeyi, A.O.; Ejiogu, I.K. Toxicity and Bioremediation of Heavy Metals Contaminated Ecosystem from Tannery Wastewater: A Review. J. Toxicol. 2018, 2018, 1-16. [CrossRef]

71. Fazli, M.M.; Soleimani, N.; Mehrasbi, M.; Darabian, S.; Mohammadi, J.; Ramazani, A. Highly cadmium tolerant fungi: Their tolerance and removal potential. J. Environ. Health Sci. Eng. 2015, 13, 1-9. [CrossRef]

72. Rzymski, P.; Poniedziałek, B.; Niedzielski, P.; Tabaczewski, P.; Wiktorowicz, K. Cadmium and lead toxicity and bioaccumulation in Microcystis aeruginosa. Front. Environ. Sci. Eng. 2014, 8, 427-432. [CrossRef]

73. Yang, J.; Cao, J.; Xing, G.; Yuan, H. Lipid production combined with biosorption and bioaccumulation of cadmium, copper, manganese and zinc by oleaginous microalgae Chlorella minutissima UTEX2341. Bioresour. Technol. 2015, 175, 537-544. [CrossRef] [PubMed]

74. Banerjee, S.; Joshi, S.R.; Mandal, T.; Halder, G. Insight into Cr6+ reduction efficiency of Rhodococcus erythropolis isolated from coalmine waste water. Chemosphere 2017, 167, 269-281. [CrossRef]

75. Manasi; Rajesh, V.; Kumar, S.K.; Rajesh, N. Biosorption of cadmium using a novel bacterium isolated from an electronic industry effluent. Chem. Eng. J. 2014, 235, 176-185. [CrossRef]

76. Masoudzadeh, N.; Zakeri, F.; Lotfabad, T.B.; Sharafi, H.; Masoomi, F.; Zahiri, H.S.; Ahmadian, G.; Noghabi, K.A. Biosorption of cadmium by Brevundimonas sp. ZF12 strain, a novel biosorbent isolated from hot-spring waters in high background radiation areas. J. Hazard. Mater. 2011, 197, 190-198. [CrossRef]

77. Zeng, Q.; Hu, Y.; Yang, Y.; Hu, L.; Zhong, H.; He, Z. Cell envelop is the key site for Cr(VI) reduction by Oceanobacillus oncorhynchi W4, a newly isolated Cr(VI) reducing bacterium. J. Hazard. Mater. 2019, 368, 149-155. [CrossRef]

78. Yaghoubian, Y.; Siadat, S.A.; Telavat, M.R.M.; Pirdashti, H.; Yaghoubian, I. Bio-removal of cadmium from aqueous solutions by filamentous fungi: Trichoderma spp. and Piriformospora indica. Environ. Sci. Pollut. Res. 2019, 26, 7863-7872. [CrossRef]

79. Iskandar, N.L.; Zainudin, N.A.I.M.; Tan, S. Tolerance and biosorption of copper $(\mathrm{Cu})$ and lead $(\mathrm{Pb})$ by filamentous fungi isolated from a freshwater ecosystem. J. Environ. Sci. 2011, 23, 824-830. [CrossRef]

80. Mohanty, K.; Murugavelh, S. MECHANISM OF Cr(VI) BIOACCUMULATION BY Phanerochaete chrysosporium. Environ. Eng. Manag. J. 2014, 13, 281-287. [CrossRef]

81. Jayanthi, M.; Kanchana, D.; Saranraj, P.; Sujitha, D. Bioadsorption of chromium by penicillium chrysogenum and aspergillus niger isolated from tannery effluent. Int. J. Microbiol. Res. 2014, 5, 40-47.

82. Mishra, A.; Malik, A. Novel fungal consortium for bioremediation of metals and dyes from mixed waste stream. Bioresour. Technol. 2014, 171, 217-226. [CrossRef] [PubMed]

83. Chellaiah, E.R. Cadmium (heavy metals) bioremediation by Pseudomonas aeruginosa: A minireview. Appl. Water Sci. 2018, 8, 154. [CrossRef]

84. Diaconu, M.; Rosca, M.; Cozma, P.; Minut, M.; Smaranda, C.; Hlihor, R.-M.; Gavrilescu, M. Toxicity and microbial bioreme-diation of chromium contaminated effluents. In Proceedings of the 2020 International Conference on e-Health and Bioengi-neering (EHB), IEEE, Iasi, Romania, 29-30 October 2020; pp. 1-4.

85. Vendruscolo, F.; Ferreira, G.L.D.R.; Filho, N.R.A. Biosorption of hexavalent chromium by microorganisms. Int. Biodeterior. Biodegrad. 2017, 119, 87-95. [CrossRef]

86. Dey, S.; Paul, A. Optimization of cultural conditions for growth associated chromate reduction by Arthrobacter sp. SUK 1201 isolated from chromite mine overburden. J. Hazard. Mater. 2012, 213-214, 200-206. [CrossRef] 
87. Poljsak, B.; Pócsi, I.; Raspor, P.; Pesti, M. Interference of chromium with biological systems in yeasts and fungi: A review: Effects of chromium on yeast and fungi. J. Basic Microbiol. 2009, 50, 21-36. [CrossRef]

88. Wilde, E.W.; Benemann, J.R. Bioremoval of heavy metals by the use of microalgae. Biotechnol. Adv. 1993, 11, 781-812. [CrossRef] [PubMed]

89. Folgar, S.; Torres, E.; Pérez-Rama, M.; Cid, A.; Herrero, C.; Abalde, J. Dunaliella salina as marine microalga highly tolerant to but a poor remover of cadmium. J. Hazard. Mater. 2009, 165, 486-493. [CrossRef]

90. Zhang, J.; Zhou, F.; Liu, Y.; Huang, F.; Zhang, C. Effect of extracellular polymeric substances on arsenic accumulation in Chlorella pyrenoidosa. Sci. Total Environ. 2020, 704, 135368. [CrossRef]

91. Priyadarshani, I.; Sahu, D.; Rath, B. Microalgal bioremediation: Current practices and perspectives. J. Biochem. Tech. 2011, 3, 299-304.

92. Să̆, Y. Biosorption of heavy metals by fungal biomass and modeling of fungal biosorption: A review. Sep. Purif. Methods 2001, 30, 1-48. [CrossRef]

93. Sher, S.; Rehman, A. Use of heavy metals resistant bacteria-A strategy for arsenic bioremediation. Appl. Microbiol. Biotechnol. 2019, 103, 6007-6021. [PubMed]

94. Hlihor, R.M.; Figueiredo, H.; Tavares, T.; Gavrilescu, M. Biosorption potential of dead and living Arthrobacter viscosus biomass in the removal of Cr (VI): Batch and column studies. Process. Saf. Environ. Prot. 2017, 108, 44-56. [CrossRef]

95. Mirghaffari, N.; Moeini, E.; Farhadian, O. Biosorption of $\mathrm{Cd}$ and $\mathrm{Pb}$ ions from aqueous solutions by biomass of the green microalga, Scenedesmus quadricauda. Scenedesmus Quadricauda. J. Appl. Phycol. 2015, 27, 311-320. [CrossRef]

96. Giovanella, P.; Cabral, L.; Bento, F.M.; Gianello, C.; Camargo, F.A.O. Mercury (II) removal by resistant bacterial isolates and mercuric (II) reductase activity in a new strain of Pseudomonas sp. B50A. New Biotechnol. 2016, 33, 216-223. [CrossRef]

97. Bowman, N.; Patel, D.; Sanchez, A.; Xu, W.; Alsaffar, A.; Tiquia-Arashiro, S.M. Lead-resistant bacteria from Saint Clair River sediments and $\mathrm{Pb}$ removal in aqueous solutions. Appl. Microbiol. Biotechnol. 2018, 102, 2391-2398. [CrossRef]

98. Paul, M.L.; Samuel, J.; Chandrasekaran, N.; Mukherjee, A. Comparative kinetics, equilibrium, thermodynamic and mechanistic studies on biosorption of hexavalent chromium by live and heat killed biomass of Acinetobacter junii VITSUKMW2, an indigenous chromite mine isolate. Chem. Eng. J. 2012, 187, 104-113. [CrossRef]

99. Huang, F.; Dang, Z.; Guo, C.-L.; Lu, G.-N.; Gu, R.R.; Liu, H.-J.; Zhang, H. Biosorption of Cd (II) by live and dead cells of Bacillus cereus RC-1 isolated from cadmium-contaminated soil. Colloids Surf. B Biointerfaces 2013, 107, 11-18. [CrossRef]

100. Wu, H.; Wu, Q.; Wu, G.; Gu, Q.; Wei, L. Cd-resistant strains of B. cereus S5 with endurance capacity and their capacities for cadmium removal from cadmium-polluted water. PLoS ONE 2016, 11, e0151479. [CrossRef]

101. Xing, S.-C.; Chen, J.-Y.; Lv, N.; Mi, J.-D.; Chen, W.L.; Liang, J.B.; Liao, X.-D. Biosorption of lead (Pb2+) by the vegetative and decay cells and spores of Bacillus coagulans R11 isolated from lead mine soil. Chemosphere 2018, 211, 804-816. [CrossRef] [PubMed]

102. Aslam, F.; Yasmin, A.; Sohail, S. Bioaccumulation of lead, chromium, and nickel by bacteria from three different genera isolated from industrial effluent. Int. Microbiol. 2020, 23, 253-261. [CrossRef]

103. Priyadarshanee, M.; Das, S. Biosorption and removal of toxic heavy metals by metal tolerating bacteria for bioremediation of metal contamination: A comprehensive review. J. Environ. Chem. Eng. 2021, 9, 104686. [CrossRef]

104. Rudakiya, D.M.; Iyer, V.; Shah, D.; Gupte, A.; Nath, K. Biosorption Potential of Phanerochaete chrysosporium for Arsenic, Cadmium, and Chromium Removal from Aqueous Solutions. Glob. Chall. 2018, 2, 1800064. [CrossRef] [PubMed]

105. Verma, A.; Singh, A.; Bishnoi, N.R.; Gupta, A. Biosorption of Cu (II) using free and immobilized biomass of Penicillium citrinum. Ecol. Eng. 2013, 61, 486-490. [CrossRef]

106. Onalo, J.I.; Matias-peralta, H.M.; Sunar, N.M. Growth of freshwater microalga, botryococcus sp. in heavy metal contaminated industrial wastewater. J. Sci. Technol. 2014, 6, 29-40.

107. Huang, R.; Huo, G.; Song, S.; Li, Y.; Xia, L.; Gaillard, J.-F. Immobilization of mercury using high-phosphate culture-modified microalgae. Environ. Pollut. 2019, 254, 112966. [CrossRef]

108. Zhang, X.; Zhao, X.; Wan, C.; Chen, B.; Bai, F. Efficient biosorption of cadmium by the self-flocculating microalga Scenedesmus obliquus AS-6-1. Algal Res. 2016, 16, 427-433. [CrossRef]

109. Wang, N.; Qiu, Y.; Xiao, T.; Wang, J.; Chen, Y.; Xu, X.; Kang, Z.; Fan, L.; Yu, H. Comparative studies on Pb(II) biosorption with three spongy microbe-based biosorbents: High performance, selectivity and application. J. Hazard. Mater. 2019, 373, 39-49. [CrossRef]

110. Peng, Y.; Deng, A.; Gong, X.; Li, X.; Zhang, Y. Coupling process study of lipid production and mercury bioremediation by biomimetic mineralized microalgae. Bioresour. Technol. 2017, 243, 628-633. [CrossRef]

111. Ahmad, N.; Mounsef, J.R.; Tayeh, J.A.; Lteif, R. Bioremediation of Ni, Al and Pb by the living cells of a resistant strain of microalga. Water Sci. Technol. 2020, 82, 851-860. [CrossRef] [PubMed]

112. Mohapatra, R.K.; Parhi, P.K.; Pandey, S.; Bindhani, B.K.; Thatoi, H.; Panda, C.R. Active and passive biosorption of Pb(II)using live and dead biomass of marine bacterium Bacillus xiamenensis PbRPSD202: Kinetics and isotherm studies. J. Environ. Manag. 2019, 247, 121-134. [CrossRef]

113. Hadiani, M.R.; Khosravi-Darani, K.; Rahimifard, N.; Younesi, H. Assessment of Mercury biosorption by Saccharomyces cerevisiae: Response surface methodology for optimization of low $\mathrm{Hg}$ (II) concentrations. J. Environ. Chem. Eng. 2018, 6, $4980-4987$. [CrossRef] 
114. Talukdar, D.; Jasrotia, T.; Sharma, R.; Jaglan, S.; Kumar, R.; Vats, R.; Kumar, R.; Mahnashi, M.H.; Umar, A. Evaluation of novel indigenous fungal consortium for enhanced bioremediation of heavy metals from contaminated sites. Environ. Technol. Innov. 2020, 20, 101050. [CrossRef]

115. Ting, A.S.Y.; Choong, C.C. Bioaccumulation and biosorption efficacy of Trichoderma isolate SP2F1 in removing copper (Cu(II)) from aqueous solutions. World J. Microbiol. Biotechnol. 2009, 25, 1431-1437. [CrossRef]

116. Sepehr, M.N.; Nasseri, S.; Zarrabi, M.; Samarghandi, M.R.; Amrane, A. Removal of Cr (III) from tanning effluent by Aspergillus niger in airlift bioreactor. Sep. Purif. Technol. 2012, 96, 256-262. [CrossRef]

117. Sharma, S.; Malaviya, P. Bioremediation of tannery wastewater by chromium resistant novel fungal consortium. Ecol. Eng. 2016, 91, 419-425. [CrossRef]

118. Dey, P.; Gola, D.; Mishra, A.; Malik, A.; Kumar, P.; Singh, D.K.; Patel, N.; von Bergen, M.; Jehmlich, N. Comparative performance evaluation of multi-metal resistant fungal strains for simultaneous removal of multiple hazardous metals. J. Hazard. Mater. 2016, 318, 679-685. [CrossRef]

119. Iram, S.; Shabbir, R.; Zafar, H.; Javaid, M. Biosorption and Bioaccumulation of Copper and Lead by Heavy Metal-Resistant Fungal Isolates. Arab. J. Sci. Eng. 2015, 40, 1867-1873. [CrossRef]

120. Chen, C.-Y.; Chang, H.-W.; Kao, P.-C.; Pan, J.-L.; Chang, J.-S. Biosorption of cadmium by CO2-fixing microalga Scenedesmus obliquus CNW-N. Bioresour. Technol. 2012, 105, 74-80. [CrossRef]

121. Nithya, K.; Sathish, A.; Pradeep, K.; Baalaji, S.K. Algal biomass waste residues of Spirulina platensis for chromium adsorption and modeling studies. J. Environ. Chem. Eng. 2019, 7, 103273. [CrossRef]

122. Pradhan, D.; Sukla, L.B.; Mishra, B.B.; Devi, N. Biosorption for removal of hexavalent chromium using microalgae Scenedesmus sp. J. Clean. Prod. 2019, 209, 617-629. [CrossRef]

123. Upadhyay, K.H.; Vaishnav, A.M.; Tipre, D.R.; Patel, B.C.; Dave, S.R. Kinetics and mechanisms of mercury biosorption by an exopolysaccharide producing marine isolate bacillus licheniformis. 3 Biotech 2017, 7, 1-10. [CrossRef]

124. Wen, X.; Du, C.; Zeng, G.; Huang, D.; Zhang, J.; Yin, L.; Tan, S.; Huang, L.; Chen, H.; Yu, G.; et al. A novel biosorbent prepared by immobilized Bacillus licheniformis for lead removal from wastewater. Chemosphere 2018, 200, 173-179. [CrossRef]

125. Arivalagan, P.; Singaraj, D.; Haridass, V.; Kaliannan, T. Removal of cadmium from aqueous solution by batch studies using Bacillus cereus. Ecol. Eng. 2014, 71, 728-735. [CrossRef]

126. Roşca, M.; Hlihor, R.-M.; Cozma, P.; Drăgoi, E.N.; Diaconu, M.; Silva, B.; Tavares, T.; Gavrilescu, M. Comparison of Rhodotorula sp. and Bacillus megaterium in the removal of cadmium ions from liquid effluents. Green Process. Synth. 2018, 7, 74-88. [CrossRef]

127. Zhang, H.; Li, H.; Li, M.; Luo, D.; Chen, Y.; Chen, D.; Luo, H.; Chen, Z.; Li, K. Immobilizing Metal-Resistant Sulfate-Reducing Bacteria for Cadmium Removal from Aqueous Solutions. Pol. J. Environ. Stud. 2018, 27, 2851-2860. [CrossRef]

128. Kulkarni, R.; Shetty, K.V.; Srinikethan, G. Cadmium (II) and nickel (II) biosorption by Bacillus laterosporus (MTCC 1628). J. Taiwan Inst. Chem. Eng. 2014, 45, 1628-1635. [CrossRef]

129. Dang, C.; Yang, Z.; Liu, W.; Du, P.; Cui, F.; He, K. Role of extracellular polymeric substances in biosorption of Pb2+ by a high metal ion tolerant fungal strain Aspergillus niger PTN31. J. Environ. Chem. Eng. 2018, 6, 2733-2742. [CrossRef]

130. Long, J.; Yuvaraja, G.; Zhou, S.; Mo, J.; Li, H.; Luo, D.; Chen, D.Y.; Kong, L.; Subbaiah, M.V.; Reddy, G.M. Inactive Fusarium Fungal strains (ZSY and MJY) isolation and application for the removal of $\mathrm{Pb}(\mathrm{II})$ ions from aqueous environment. J. Ind. Eng. Chem. 2019, 72, 442-452. [CrossRef]

131. Hlihor, R.M.; Diaconu, M.; Gavrilescu, M. A Comparison of kinetic models applied for Cd (II) removal by S. cerevisiae. Bull. Polytech. Inst. Jassy 2011, LVII, 163-171.

132. Samuel, M.S.; Chidambaram, R. Hexavalent chromium biosorption studies using Penicillium griseofulvum MSR1 a novel isolate from tannery effluent site: Box-Behnken optimization, equilibrium, kinetics and thermodynamic studies. J. Taiwan Inst. Chem. Eng. 2015, 49, 156-164. [CrossRef]

133. Verma, J.P.; Jaiswal, D.K.; Sagar, R. Pesticide relevance and their microbial degradation: A-state-of-art. Rev. Environ. Sci. Bio/Technol. 2014, 13, 429-466. [CrossRef]

134. Savoca, D.; Pace, A. Bioaccumulation, Biodistribution, Toxicology and Biomonitoring of Organofluorine Compounds in Aquatic Organisms. Int. J. Mol. Sci. 2021, 22, 6276. [CrossRef]

135. Al-Mamun, A. Pesticide degradations, residues and environmental concerns. In Pesticide Residue in Foods; Khan, M.S., Rahman, M.S., Eds.; Springer International Publishing: Cham, Switzerland, 2017; pp. 87-102. ISBN 978-3-319-52681-2.

136. Srivastava, J.; Naraian, R.; Kalra, S.J.S.; Chandra, H. Advances in microbial bioremediation and the factors influencing the process Int. J. Environ. Sci. Technol. 2014, 11, 1787-1800. [CrossRef]

137. Xiong, Q.; Hu, L.-X.; Liu, Y.-S.; Zhao, J.-L.; He, L.-Y.; Ying, G.-G. Microalgae-based technology for antibiotics removal: From mechanisms to application of innovational hybrid systems. Environ. Int. 2021, 155, 106594. [CrossRef] [PubMed]

138. Adewuyi, A. Chemically Modified Biosorbents and Their Role in the Removal of Emerging Pharmaceutical Waste in the Water System. Water 2020, 12, 1551. [CrossRef]

139. Aksu, Z. Application of biosorption for the removal of organic pollutants: A review. Process. Biochem. 2005, 40, 997-1026. [CrossRef]

140. Ju, Y.-H.; Chen, T.-C.; Liu, J. A study on the biosorption of lindane. Colloids Surf. B Biointerfaces 1997, 9, 187-196. [CrossRef]

141. Bell, J.P.; Tsezos, M. Removal of Hazardous Organic Pollutants by Adsorption on Microbial Biomass. Water Sci. Technol. 1987, 19, 409-416. [CrossRef] 
142. Young, E.; Banks, C. The Removal of Lindane from Aqueous Solution using a Fungal Biosorbent: The Influence of $\mathrm{pH}$, Temperature, Biomass Concentration, and Culture Age. Environ. Technol. 1998, 19, 619-625. [CrossRef]

143. Hong, H.-B.; Hwang, S.; Chang, Y.-S. Biosorption of 1,2,3,4-tetrachlorodibenzo-p-dioxin and polychlorinated dibenzofurans by Bacillus pumilus. Water Res. 2000, 34, 349-353. [CrossRef]

144. Benoit, P.; Barriuso, E.; Calvet, R. Biosorption characterization of herbicides, 2,4-D and atrazine, and two chlorophenols on fungal mycelium. Chemosphere 1998, 37, 1271-1282. [CrossRef]

145. Nayak, S.K.; Dash, B.; Baliyarsingh, B. Microbial remediation of persistent agro-chemicals by soil bacteria: An overview. In Microbial Biotechnology; Springer Science and Business Media LLC: New York, NY, USA, 2018; ISBN 9789811071409.

146. Huang, L.; Wang, W.; Shah, S.B.; Hu, H.; Xu, P.; Tang, H. The HBCDs biodegradation using a Pseudomonas strain and its application in soil phytoremediation. J. Hazard. Mater. 2019, 380, 120833. [CrossRef] [PubMed]

147. Li, Y.-J.; Wang, R.; Lin, C.-Y.; Chen, S.-H.; Chuang, C.-H.; Chou, T.-H.; Ko, C.-F.; Chou, P.-H.; Liu, C.-T.; Shih, Y.-H. The degradation mechanisms of Rhodopseudomonas palustris toward hexabromocyclododecane by time-course transcriptome analysis. Chem. Eng. J. 2021, 425, 130489. [CrossRef]

148. Guillén-Jiménez, F.D.M.; Cristiani-Urbina, E.; Cancino-Díaz, J.C.; Flores-Moreno, J.L.; Barragán-Huerta, B.E. Lindane biodegradation by the Fusarium verticillioides AT-100 strain, isolated from Agave tequilana leaves: Kinetic study and identification of metabolites. Int. Biodeterior. Biodegrad. 2012, 74, 36-47. [CrossRef]

149. Wu, Z.; Xie, M.; Li, Y.; Gao, G.; Bartlam, M.; Wang, Y. Biodegradation of decabromodiphenyl ether (BDE 209) by a newly isolated bacterium from an e-waste recycling area. AMB Express 2018, 8, 27. [CrossRef]

150. Shi, G.; Yin, H.; Ye, J.; Peng, H.; Li, J.; Luo, C. Aerobic biotransformation of decabromodiphenyl ether (PBDE-209) by Pseudomonas aeruginosa. Chemosphere 2013, 93, 1487-1493. [CrossRef]

151. Ozdal, M.; Ozdal, O.G.; Algur, O.F.; Kurbanoglu, E.B. Biodegradation of $\alpha$-endosulfan via hydrolysis pathway by Stenotrophomonas maltophilia OG2. 3 Biotech 2017, 7, 113. [CrossRef] [PubMed]

152. Silambarasan, S.; Abraham, J. Mycoremediation of Endosulfan and Its Metabolites in Aqueous Medium and Soil by Botryosphaeria laricina JAS6 and Aspergillus tamarii JAS9. PLoS ONE 2013, 8, e77170. [CrossRef]

153. Mano, D.M.; Buff, K.; Clausen, E.; Langenbach, T. Bioaccumulation and enhanced persistence of the acaricide Dicofol by Azospirillum lipoferum. Chemosphere 1996, 33, 1609-1619. [CrossRef]

154. Gianfreda, L.; Mora, M.L.; Diez, M.C. Restoration of polluted soils by means of microbial and enzymatic processes. Azospirillum Lipoferum. Chemosphere 2006, 6, 20-40. [CrossRef]

155. Bhandari, S.; Poudel, D.K.; Marahatha, R.; Dawadi, S.; Khadayat, K.; Phuyal, S.; Shrestha, S.; Gaire, S.; Basnet, K.; Khadka, U.; et al. Microbial Enzymes Used in Bioremediation. J. Chem. 2021, 2021, 1-17. [CrossRef]

156. Bhatt, P.; Verma, A.; Gangola, S.; Bhandari, G.; Chen, S. Microbial glycoconjugates in organic pollutant bioremediation: Recent advances and applications. Microb. Cell Factories 2021, 20, 72. [CrossRef]

157. Karigar, C.S.; Rao, S.S. Role of Microbial Enzymes in the Bioremediation of Pollutants: A Review. Enzyme Res. $2011,2011,1-11$. [CrossRef]

158. Xu, A.; Zhang, X.; Wu, S.; Xu, N.; Huang, Y.; Yan, X.; Zhou, J.; Cui, Z.; Dong, W. Pollutant Degrading Enzyme: Catalytic Mechanisms and Their Expanded Applications. Molecules 2021, 26, 4751. [CrossRef]

159. Katarína, D.; Slavomíra, M.; Hana, D.; Katarína, L.; Hana, H. The adaptation mechanisms of bacteria applied in bioremediation of hydrophobic toxic environmental pollutants: How indigenous and introduced bacteria can respond to persistent organic pollutants-induced stress. In Persistent Organic Pollutants; Donyinah, S.K., Ed.; IntechOpen: Rijeka, Croatia, 2019; ISBN 978-1-78985-807-5.

160. Olicón-Hernández, D.R.; González-López, J.; Aranda, E. Overview on the biochemical potential of filamentous fungi to degrade pharmaceutical compounds. Front. Microbiol. 2017, 8, 1792. [CrossRef]

161. Davolos, D.; Russo, F.; Canfora, L.; Malusà, E.; Tartanus, M.; Furmanczyk, E.; Ceci, A.; Maggi, O.; Persiani, A. A Genomic and transcriptomic study on the DDT-resistant Trichoderma hamatum FBL 587: First Genetic Data into Mycoremediation Strategies for DDT-Polluted Sites. Microorganisms 2021, 9, 1680. [CrossRef]

162. Dalton, H.; Stirling, D.I.; Quayle, J.R. Co-metabolism. Philos. Trans. R. Soc. Lond. B Biol. Sci. 1982, 297, 481-496. [CrossRef] [PubMed]

163. Nzila, A. Update on the cometabolism of organic pollutants by bacteria. Environ. Pollut. 2013, 178, 474-482. [CrossRef]

164. Alvarez, A.; Benimeli, C.S.; Saez, J.M.; Fuentes, M.S.; Cuozzo, S.A.; Polti, M.A.; Amoroso, M.J. Bacterial bio-resources for remediation of hexachlorocyclohexane. Int. J. Mol. Sci. 2012, 13, 15086-15106. [CrossRef]

165. Wang, G.; Zhang, J.; Wang, L.; Liang, B.; Chen, K.; Li, S.; Jiang, J. Co-metabolism of DDT by the newly isolated bacterium, Pseudoxanthomonas sp. wax. Braz. J. Microbiol. 2010, 41, 431-438. [CrossRef] [PubMed]

166. Dey, A.; Sarkar, P.; Das, A. Studies on biodegradation of 4-chlorophenol and 4-nitrophenol by isolated pure cultures. Eur. J. Sustain. Dev. 2019, 8, 281. [CrossRef]

167. Khessairi, A.; Fhoula, I.; Jaouani, A.; Turki, Y.; Cherif, A.; Boudabous, A.; Hassen, A.; Ouzari, H. Pentachlorophenol degradation by Janibactersp., a new actinobacterium isolated from saline sediment of arid land. BioMed Res. Int. 2014, 2014, 1-9. [CrossRef]

168. Abdul Salam, J.; Lakshmi, V.; Das, D.; Das, N. Biodegradation of lindane using a novel yeast strain, rhodotorula sp. VITJzN03 isolated from agricultural soil. World J. Microbiol. Biotechnol. 2013, 29, 475-487. [CrossRef] [PubMed] 
169. Chang, Y.-S. Recent developments in microbial biotransformation and biodegradation of dioxins. J. Mol. Microbiol. Biotechnol. 2008, 15, 152-171. [CrossRef] [PubMed]

170. Sakaki, T.; Munetsuna, E. Enzyme systems for biodegradation of polychlorinated dibenzo-p-dioxins. Appl. Microbiol. Biotechnol. 2010, 88, 23-30. [CrossRef]

171. Nguyen, B.-A.T.; Hsieh, J.-L.; Lo, S.-C.; Wang, S.-Y.; Hung, C.-H.; Huang, E.; Hung, S.-H.; Chin, W.-C.; Huang, C.-C. Biodegradation of dioxins by Burkholderia cenocepacia strain 869T2: Role of 2-haloacid dehalogenase. J. Hazard. Mater. 2021, $401,123347$. [CrossRef] [PubMed]

172. Nagata, Y.; Kato, H.; Ohtsubo, Y.; Tsuda, M. Lessons from the genomes of lindane-degrading sphingomonads. Environ. Microbiol. Rep. 2019, 11, 630-644. [CrossRef]

173. Asemoloye, M.D.; Ahmad, R.; Jonathan, S.G. Synergistic rhizosphere degradation of $\gamma$-hexachlorocyclohexane (lindane) through the combinatorial plant-fungal action. PLOS ONE 2017, 12, e0183373. [CrossRef]

174. Salam, J.A.; Das, N. Lindane degradation by Candida VITJzN04, a newly isolated yeast strain from contaminated soil: Kinetic study, enzyme analysis and biodegradation pathway. World J. Microbiol. Biotechnol. 2014, 30, 1301-1313. [CrossRef] [PubMed]

175. Weir, K.M.; Sutherland, T.D.; Horne, I.; Russell, R.J.; Oakeshott, J.G. A single monooxygenase, ese, is involved in the metabolism of the organochlorides endosulfan and endosulfate in an Arthrobacter sp. Appl. Environ. Microbiol. 2006, 72, 3524-3530. [CrossRef] [PubMed]

176. Copley, S.D.; Rokicki, J.; Turner, P.; Daligault, H.; Nolan, M.; Land, M. The whole genome sequence of sphingobium chlorophenolicum L-1: Insights into the evolution of the pentachlorophenol degradation pathway. Genome Biol. Evol. 2012, 4, 184-198. [CrossRef]

177. Lopez-Echartea, E.; Macek, T.; Demnerova, K.; Uhlik, O. Bacterial biotransformation of pentachlorophenol and micropollutants formed during its production process. Int. J. Environ. Res. Public Health 2016, 13, 1146. [CrossRef]

178. Shah, S.B.; Ali, F.; Huang, L.; Wang, W.; Xu, P.; Tang, H. Complete genome sequence of Bacillus sp. HBCD-sjtu, an efficient HBCD-degrading bacterium. 3 Biotech 2018, 8, 291. [CrossRef] [PubMed]

179. Yu, Y.; Yin, H.; Peng, H.; Lu, G.; Dang, Z. Biodegradation of decabromodiphenyl ether (BDE-209) using a novel microbial consortium GY1: Cells viability, pathway, toxicity assessment, and microbial function prediction. Sci. Total Environ. 2019, 668, 958-965. [CrossRef]

180. Suman, S.; Tanuja. Isolation and characterization of a bacterial strain enterobacter cloacae (Accession No. KX438060.1) capable of degrading DDTs under aerobic conditions and its use in bioremediation of contaminated soil. Microbiol. Insights 2021, 14. [CrossRef]

181. Gavrilescu, M.; Fortuna, M.E.; Simion, I.M. Sustainability in environmental remediation. Environ. Eng. Manag. J. 2011, 10, 1987-1996. [CrossRef]

182. Tahri, N.; Bahafid, W.; Sayel, H.; El Ghachtouli, N. Biodegradation: Involved microorganisms. In Biodegradation-Life of Science; Chamy, R., Ed.; InTech: Rijeka, Croatia, 2013; pp. 1-7. ISBN 978-953-51-1154-2.

183. Doolotkeldieva, T.; Bobusheva, S.; Konurbaeva, M. The improving conditions for the aerobic bacteria performing the degradation of obsolete pesticides in polluted soils. Air Soil Water Res. 2021, 14. [CrossRef]

184. Osman, K.A.; Ibrahim, G.H.; Askar, A.I.; Alkhail, A.R.A.A. Biodegradation kinetics of dicofol by selected microorganisms. Pestic. Biochem. Physiol. 2008, 91, 180-185. [CrossRef]

185. Kumar, D.; Kumar, A.; Sharma, J. Degradation study of lindane by novel strains Kocuria sp. DAB-1Y and Staphylococcus sp. DAB-1W. Bioresour. Bioprocess. 2016, 3, 53. [CrossRef] [PubMed]

186. Singh, T.; Singh, D.K. Lindane degradation by root epiphytic bacteriumAchromobactersp. strain A3 fromAcorus calamusand characterization of associated proteins. Int. J. Phytoremediation 2019, 21, 419-424. [CrossRef] [PubMed]

187. Singh, T.; Singh, D.K. Rhizospheric microbacterium sp. P27 showing potential of lindane degradation and plant growth promoting traits. Curr. Microbiol. 2019, 76, 888-895. [CrossRef] [PubMed]

188. Sahoo, B.; Ningthoujam, R.; Chaudhuri, S. Isolation and characterization of a lindane degrading bacteria Paracoccus sp. NITDBR1 and evaluation of its plant growth promoting traits. Int. Microbiol. 2019, 22, 155-167. [CrossRef]

189. Ahmad, K.S. Remedial potential of bacterial and fungal strains (Bacillus subtilis, Aspergillus niger, Aspergillus flavus and Penicillium chrysogenum) against organochlorine insecticide Endosulfan. Folia Microbiol. 2020, 65, 801-810. [CrossRef]

190. Yamada, T.; Takahama, Y.; Yamada, Y. Isolation of Pseudomonassp. Strain HB01 which degrades the persistent brominated flame retardant $\gamma$-hexabromocyclododecane. Biosci. Biotechnol. Biochem. 2009, 73, 1674-1678. [CrossRef]

191. Lu, P.; Liu, H.-M.; Liu, A.-M. Biodegradation of dicofol by Microbacterium sp. D-2 isolated from pesticide-contaminated agricultural soil. Appl. Biol. Chem. 2019, 62, 72. [CrossRef]

192. Kumar, D.; Pannu, R. Perspectives of lindane ( $\gamma$-hexachlorocyclohexane) biodegradation from the environment: A review. Bioresour. Bioprocess. 2018, 5, 29. [CrossRef]

193. Cao, H.; Wang, C.; Liu, H.; Jia, W.; Sun, H. Enzyme activities during Benzo[a]pyrene degradation by the fungus Lasiodiplodia theobromae isolated from a polluted soil. Sci. Rep. 2020, 10, 865. [CrossRef]

194. Qi, Y.; Zhao, L.; Ojekunle, Z.O.; Tan, X. Isolation and preliminary characterization of a 3-chlorobenzoate degrading bacteria. J. Environ. Sci. 2007, 19, 332-337. [CrossRef]

195. Kataoka, R. Biodegradability and biodegradation pathways of chlorinated cyclodiene insecticides by soil fungi. J. Pestic. Sci. 2018, 43, 314-320. [CrossRef] 
196. Sandhibigraha, S.; Chakraborty, S.; Bandyopadhyay, T.; Bhunia, B. A kinetic study of 4-chlorophenol biodegradation by the novel isolated Bacillus subtilis in batch shake flask. Environ. Eng. Res. 2019, 25, 62-70. [CrossRef]

197. Sing, N.N.; Zulkharnain, A.; Roslan, H.A.; Assim, Z.; Husaini, A. Bioremediation of PCP by Trichoderma and Cunninghamella Strains Isolated from Sawdust. Braz. Arch. Biol. Technol. 2014, 57, 811-820. [CrossRef]

198. Wang, J.; Huang, T.; Tao, X.; Li, H.; Duan, X.; Zou, M.; Lu, G. Rapid biodegradation of 2,2',4,4'-tetrabromodiphenyl ether (BDE-47) by Achromobacter xylosoxidans GYP4. Desalination Water Treat. 2019, 162, 353-363. [CrossRef]

199. Ammeri, R.W.; Mehri, I.; Badi, S.; Hassen, W.; Hassen, A. Pentachlorophenol degradation by Pseudomonas fluorescens. Water Qual. Res. J. 2017, 52, 99-108. [CrossRef]

200. Mandal, S.K.; Das, N. Biodegradation of benzo [a] pyrene by Rhodotorula sp. NS01 strain isolated from contaminated soil sample. Res. J. Pharm. Technol. 2017, 10, 1751. [CrossRef]

201. Wang, J.; Ma, X.; Liu, S.; Sun, P.; Fan, P.; Xia, C. Biodegradation of Phenol and 4-Chlorophenol by Candida tropicalis W1. Procedia Environ. Sci. 2012, 16, 299-303. [CrossRef]

202. Ahn, T.-S.; Lee, G.-H.; Song, H.-G. Biodegradation of phenanthrene by psychrotrophic bacteria from Lake Baikal. J. Microbiol. Biotechnol. 2005, 15, 1135-1139.

203. Zheng, G.; Selvam, A.; Wong, J.W. Rapid degradation of lindane ( $\gamma$-hexachlorocyclohexane) at low temperature by Sphingobium strains. Int. Biodeterior. Biodegrad. 2011, 65, 612-618. [CrossRef]

204. Michaud, L.; Di Marco, G.; Bruni, V.; Giudice, A.L. Biodegradative potential and characterization of psychrotolerant polychlorinated biphenyl-degrading marine bacteria isolated from a coastal station in the Terra Nova Bay (Ross Sea, Antarctica). Mar. Pollut. Bull. 2007, 54, 1754-1761. [CrossRef]

205. Eltoukhy, A.; Jia, Y.; Nahurira, R.; Abo-Kadoum, M.A.; Khokhar, I.; Wang, J.; Yan, Y. Biodegradation of endocrine disruptor Bisphenol A by Pseudomonas putida strain YC-AE1 isolated from polluted soil, Guangdong, China. BMC Microbiol. $2020,20,11$. [CrossRef]

206. Grewal, J.; Bhattacharya, A.; Kumar, S.; Singh, D.K.; Khare, S.K. Biodegradation of 1,1,1-trichloro-2,2-bis(4-chlorophenyl) ethane (DDT) by usingSerratia marcescensNCIM 2919. J. Environ. Sci. Health Part B 2016, 51, 809-816. [CrossRef]

207. Li, G.; Zu, L.; Wong, P.-K.; Hui, X.; Lu, Y.; Xiong, J.; An, T. Biodegradation and detoxification of bisphenol A with one newlyisolated strain Bacillus sp. GZB: Kinetics, mechanism and estrogenic transition. Bioresour. Technol. 2012, 114, 224-230. [CrossRef]

208. Kumar, A.; Bhoot, N.; Soni, I.; John, P.J. Isolation and characterization of a Bacillus subtilis strain that degrades endosulfan and endosulfan sulfate. 3 Biotech 2014, 4, 467-475. [CrossRef] [PubMed]

209. Ghosh, S.; Das, S.K.; Guha, A.K.; Sanyal, A.K. Adsorption behavior of lindane on Rhizopus oryzae biomass: Physico-chemical studies. J. Hazard. Mater. 2009, 172, 485-490. [CrossRef] [PubMed]

210. Lièvremont, D.; Seigle-Murandi, F.; Benoit-Guyod, J.-L. Removal of PCNB from aqueous solution by a fungal adsorption process. Water Res. 1998, 32, 3601-3606. [CrossRef]

211. De, J.; Ramaiah, N.; Vardanyan, L. Detoxification of Toxic Heavy Metals by Marine Bacteria Highly Resistant to Mercury. Mar. Biotechnol. 2008, 10, 471-477. [CrossRef]

212. Kapahi, M.; Sachdeva, S. Bioremediation Options for Heavy Metal Pollution. J. Health Pollut. 2019, 9, 191203. [CrossRef]

213. Javaid, A.; Bajwa, R.; Shafique, U.; Anwar, J. Removal of heavy metals by adsorption on Pleurotus ostreatus. Biomass- Bioenergy 2011, 35, 1675-1682. [CrossRef]

214. Kanamarlapudi, S.L.R.K.; Chintalpudi, V.K.; Muddada, S. Application of biosorption for removal of heavy metals from wastewater. In Biosorption; Derco, J., Vrana, B., Eds.; InTech: Rijeka, Croatia, 2018; ISBN 978-1-78923-472-5.

215. Qamouche, K.; Chetaine, A.; El Yahyaoui, A.; Moussaif, A.; Fröhlich, P.; Bertau, M.; Haneklaus, N. Uranium and other heavy metal sorption from Moroccan phosphoric acid with argan nutshell sawdust. Miner. Eng. 2021, 171, 107085. [CrossRef]

216. Piccinno, F.; Hischier, R.; Seeger, S.; Som, C. Life cycle assessment of a new technology to extract, functionalize and orient cellulose nanofibers from food waste. ACS Sustain. Chem. Eng. 2015, 3, 1047-1055. [CrossRef]

217. Crater, J.S.; Lievense, J.C. Scale-up of industrial microbial processes. FEMS Microbiol. Lett. 2018, 365, fny138. [CrossRef]

218. Dumpala, R.; Bhavsar, J.; Patil, C. Scaleup factors with an industrial perspective. Int. J. Univers. Pharm. Bio Sci. 2020, 9, 1-13.

219. Tsoy, N.; Steubing, B.; Van Der Giesen, C.; Guinée, J. Upscaling methods used in ex ante life cycle assessment of emerging technologies: A review. Int. J. Life Cycle Assess. 2020, 25, 1680-1692. [CrossRef]

220. Shibasaki, M.; Warburg, N.; Eyerer, P. Upscaling Effect and Life Cycle Assessment. Proceedings of 13th CIRP International Conference of Life Cycle Engineering (LCE 2006), Leuven, Belgium, 31 May-2 June 2006; pp. 61-64.

221. Von Drachenfels, N.; Engels, P.; Husmann, J.; Cerdas, F.; Herrmann, C. Scale-Up of pilot line battery cell manufacturing life cycle inventory models for life cycle assessment. Procedia CIRP 2021, 98, 13-18. [CrossRef]

222. Ghiron, L.; Shillingi, L.; Kabiswa, C.; Ogonda, G.; Omimo, A.; Ntabona, A.; Simmons, R.; Fajans, P. Beginning with sustainable scale up in mind: Initial results from a population, health and environment project in East Africa. Reprod. Health Matters 2014, 22, 84-92. [CrossRef] 